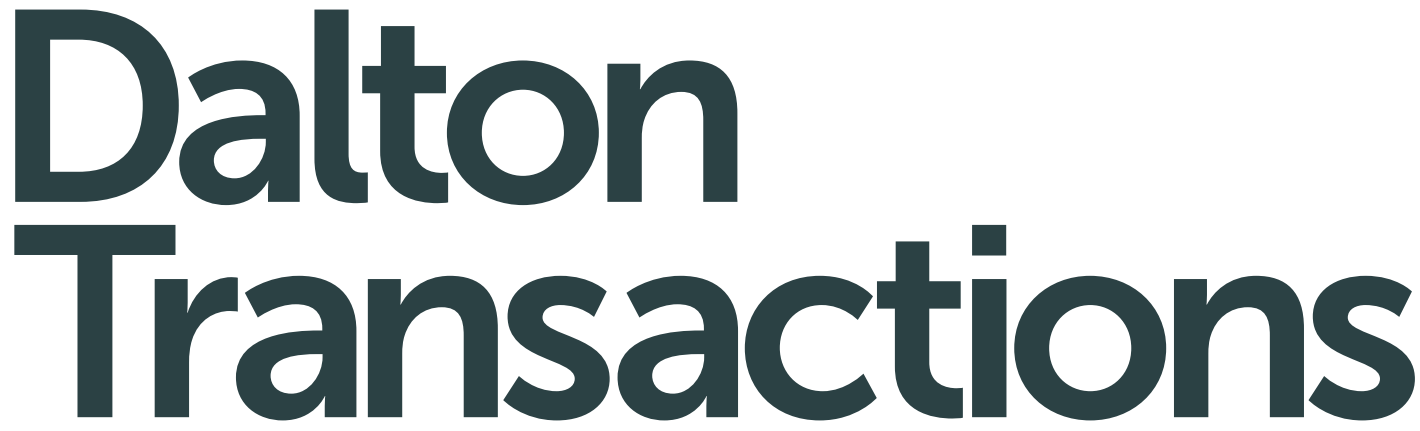

An international journal of inorganic chemistry www.rsc.org/dalton
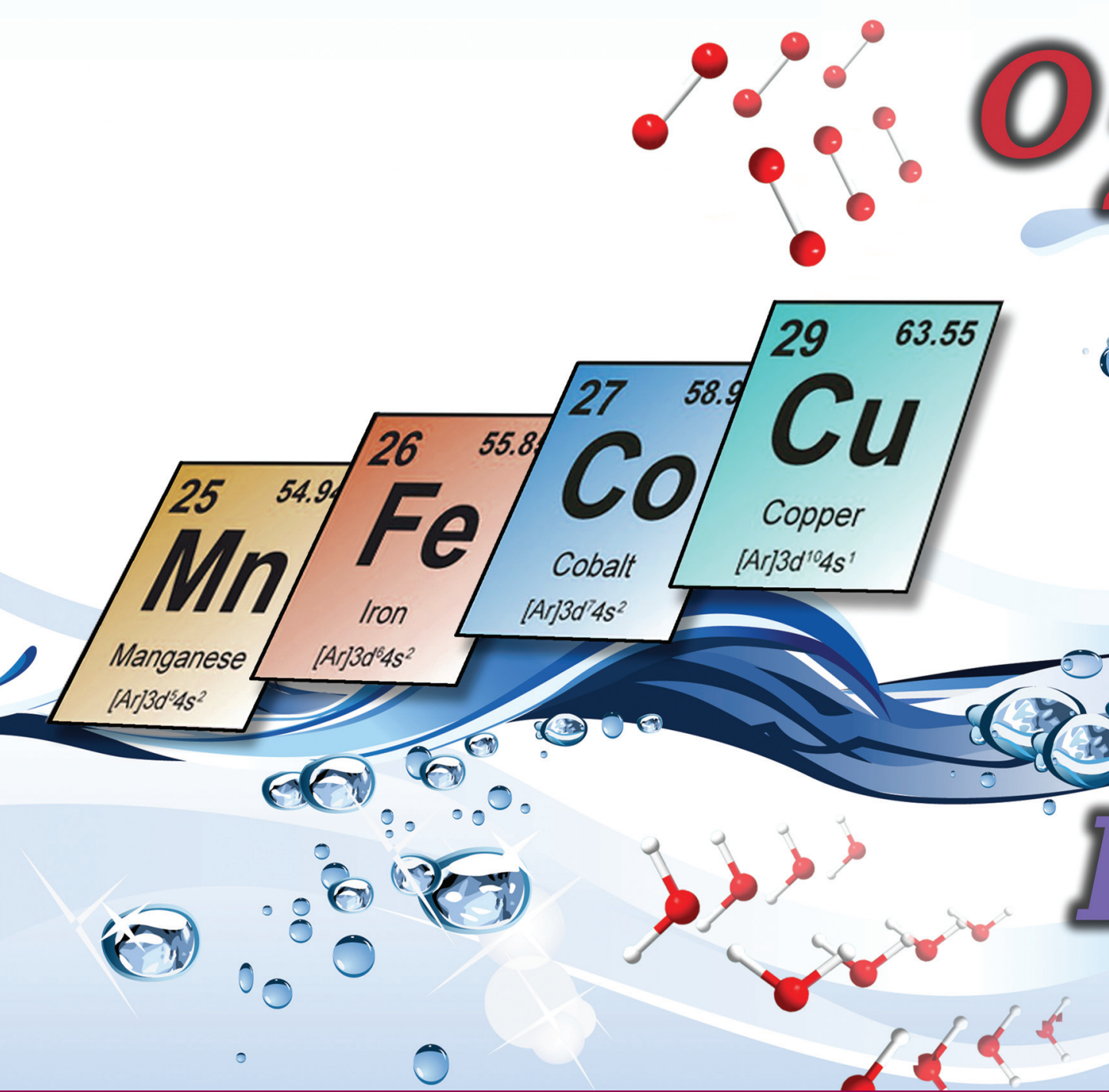


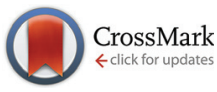

Cite this: Dalton Trans., 2016, 45, 14421

Received 29th February 2016 Accepted 31st March 2016

DOI: $10.1039 / c 6 d t 00809 g$

www.rsc.org/dalton

\section{Water oxidation using earth-abundant transition metal catalysts: opportunities and challenges}

\author{
Markus D. Kärkäs* and Björn Åkermark* \\ Catalysts for the oxidation of $\mathrm{H}_{2} \mathrm{O}$ are an integral component of solar energy to fuel conversion techno- \\ logies. Although catalysts based on scarce and precious metals have been recognized as efficient catalysts \\ for $\mathrm{H}_{2} \mathrm{O}$ oxidation, catalysts composed of inexpensive and earth-abundant element(s) are essential for \\ realizing economically viable energy conversion technologies. This Perspective summarizes recent \\ advances in the field of designing homogeneous water oxidation catalysts (WOCs) based on Mn, Fe, Co \\ and $\mathrm{Cu}$. It reviews the state of the art catalysts, provides insight into their catalytic mechanisms and \\ discusses future challenges in designing bioinspired catalysts based on earth-abundant metals for the \\ oxidation of $\mathrm{H}_{2} \mathrm{O}$.
}

\section{Introduction}

Our society's growing energy demands and the impact of rising $\mathrm{CO}_{2}$ emissions have resulted in the awareness of the necessity of developing sustainable and carbon-neutral alternatives to fossil fuels. ${ }^{1-3}$ of the possible sustainable energy sources, only solar energy has the potential to meet the global energy demands. In this context, an attractive way of harnessing solar energy is artificial photosynthesis, where solar energy is employed to split $\mathrm{H}_{2} \mathrm{O}$ into $\mathrm{O}_{2}$ and a fuel, $\mathrm{H}_{2}$ (eqn (1)), thus storing the energy provided by the sun in chemical bonds. Therefore, methods for converting and storing solar energy are being intensively pursued: ${ }^{4-6}$

$$
2 \mathrm{H}_{2} \mathrm{O} \rightarrow \mathrm{O}_{2}+2 \mathrm{H}_{2}
$$

Owing to its natural abundance, $\mathrm{H}_{2} \mathrm{O}$ would be the ideal source of reducing equivalents, i.e. protons and electrons. However, the development of efficient catalysts for the oxidation of $\mathrm{H}_{2} \mathrm{O}$ remains a bottleneck in the development of technologies for the conversion of solar energy into fuels. ${ }^{7}$ The natural photosynthesis provides a brilliant strategy for harnessing sunlight and using it to oxidize $\mathrm{H}_{2} \mathrm{O}$ to $\mathrm{O}_{2}$ in order to generate the necessary reducing equivalents for producing biomass by reducing $\mathrm{CO}_{2}$ to carbohydrates. This process, which takes place in the photosynthetic machinery of green plants and cyanobacteria, is the basis for a major part of our global energy supplies and is thus a crucial reaction in order to sustain life on earth. ${ }^{8,9}$

Department of Organic Chemistry, Arrhenius Laboratory, Stockholm University, SE-10691 Stockholm, Sweden.E-mail:markus.karkas@su.se, bjorn.akermark@su.se

\subsection{Photosynthesis - light-harvesting for the oxidation of $\mathrm{H}_{2} \mathrm{O}$}

The initial step in the photosynthetic machinery involves light absorption aided by photosynthetic pigments. The energy is subsequently funneled to the central $\mathrm{P}_{680}$ reaction center, resulting in charge separation to give the oxidized $\mathrm{P}_{680}\left(\mathrm{P}_{680}{ }^{+}\right)$. Reduction of $\mathrm{P}_{680}{ }^{+}$occurs by abstraction of an electron from the $\mathrm{Mn}_{4} \mathrm{Ca}$ cluster located in the oxygen-evolving complex (OEC). After four consecutive electron transfers, the $\mathrm{Mn}_{4} \mathrm{Ca}$ cluster is regenerated by formally oxidizing two molecules of $\mathrm{H}_{2} \mathrm{O}$ to $\mathrm{O}_{2}\left(\right.$ eqn (2)): ${ }^{10,11}$

$$
2 \mathrm{H}_{2} \mathrm{O} \rightarrow \mathrm{O}_{2}+4 \mathrm{H}^{+}+4 \mathrm{e}^{-}
$$

$\mathrm{X}$-ray crystallography has revealed that the OEC is composed of a cuboidal $\mathrm{Mn}_{3} \mathrm{Ca}$ core with a dangling $\mathrm{Mn}$ center (Fig. 1). ${ }^{12-15}$ The mechanism by which this Mn cluster catalyzes the oxidation of $\mathrm{H}_{2} \mathrm{O}$ is currently fairly well understood. However, some questions still remain unsolved and it is therefore still actively studied with the view that further insight into the mechanism is important for the design of artificial systems for solar energy to fuel conversion. ${ }^{16-22}$

\subsection{Artificial photosynthesis}

In contrast to natural photosynthesis where the protons and electrons produced from $\mathrm{H}_{2} \mathrm{O}$ oxidation are used to convert $\mathrm{CO}_{2}$ to biomass, in artificial systems they are converted into simpler chemical fuels, such as $\mathrm{H}_{2}$. The light-driven $\mathrm{H}_{2} \mathrm{O}$ splitting requires the orchestration of several intricate processes, such as light absorption, charge separation, oxidation of $\mathrm{H}_{2} \mathrm{O}$ and reduction of the generated protons. ${ }^{4}$ In artificial photosynthetic systems, catalysts for the oxidation of $\mathrm{H}_{2} \mathrm{O}$ are currently the bottleneck. To catalyze such an energy demanding reaction 


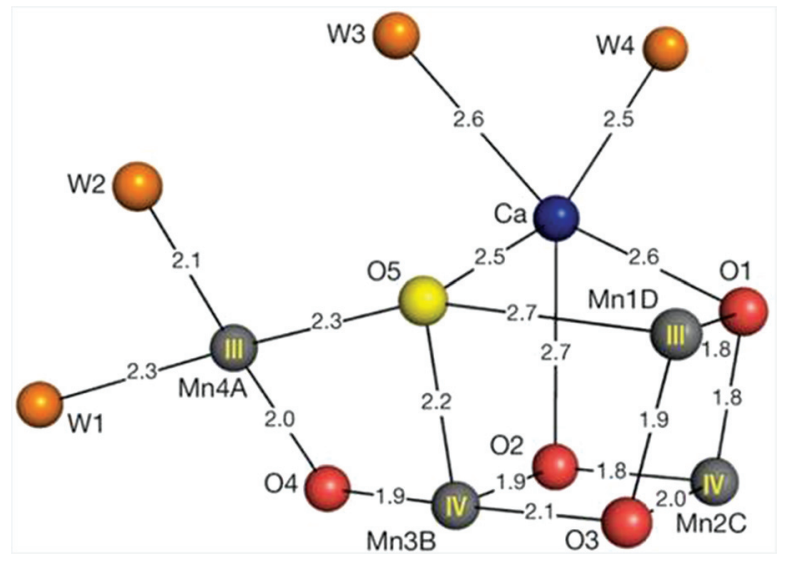

Fig. 1 Structure of the $\mathrm{Mn}_{4} \mathrm{Ca}$ cluster in the oxygen-evolving complex (OEC). Distances for $\mathrm{Mn}-\mathrm{O}, \mathrm{Ca}-\mathrm{O}, \mathrm{Mn}$-water and $\mathrm{Ca}$-water are given in Ångstrom. Reprinted with permission from ref. 12. Copyright $2015 \mathrm{Mac}-$ millan Publishers Ltd.

as $\mathrm{H}_{2} \mathrm{O}$ oxidation, the catalysts should be able to accumulate several oxidizing equivalents, forming the essential $\mathrm{O}-\mathrm{O}$ bond, and operate close to the thermodynamic potential. ${ }^{7}$ The design of artificial water oxidation catalysts (WOCs) thus represents a fundamental challenge in schemes for artificial photosynthesis and has therefore been the major focus of research during the past few decades. ${ }^{23}$

The majority of homogeneous WOCs are based on the second- and third-row transition metals $\mathrm{Ru}$ and $\mathrm{Ir}^{24} \mathrm{Com-}$

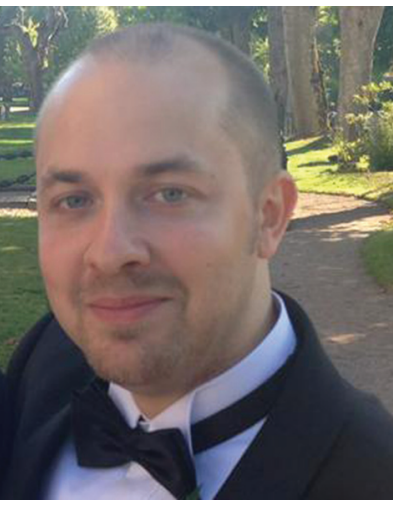

Markus D. Kärkäs
Markus D. Kärkäs received his M.Sc. degree in Chemistry from Stockholm University in 2008, where he conducted undergraduate research in the laboratory of Prof. Akermark. In the same year, he began his Ph.D. studies under the guidance of Professor Björn Åkermark and Professor Jan-Erling Bäckvall. In 2013, he obtained his Ph.D. degree after conducting research on the development of artificial water oxidation catalysts. He is currently a Swedish Research Council Postdoctoral Fellow at the University of Michigan in the group of Professor Corey Stephenson where he is developing methods for the valorization of lignin.

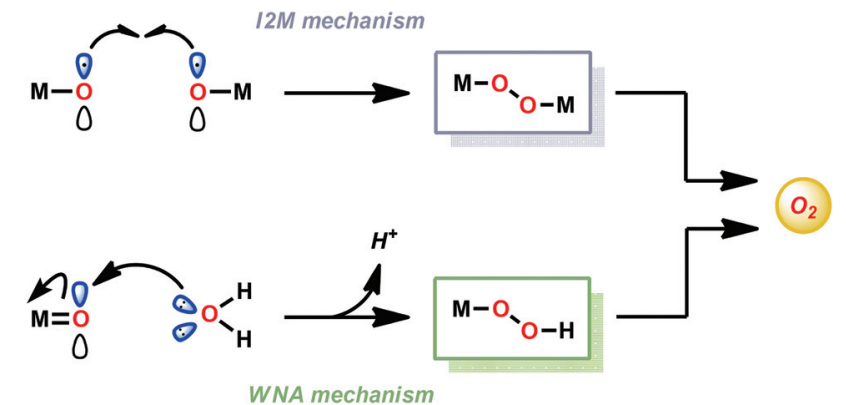

Fig. 2 O-O bond formation pathways for Ru- and Ir-based water oxidation catalysts (WOCs).

plexes based on these metals have been shown to produce robust and highly active WOCs, and are, in general, thought to generate the vital $\mathrm{O}-\mathrm{O}$ bond either via the water nucleophilic attack (WNA) mechanism or the interaction of two metal-oxo units (I2M) (see Fig. 2). ${ }^{25-28}$

If water splitting is to become economically viable on a global scale, the high cost and low abundance associated with transition metals, such as Ru and Ir, may become a problem. The construction of WOCs based on earth-abundant first-row transition metals is therefore highly desirable. Despite considerable efforts, the development of robust WOCs incorporating first-row elements that operate under mild conditions has proven particularly challenging. ${ }^{29-32}$ However, if successful,

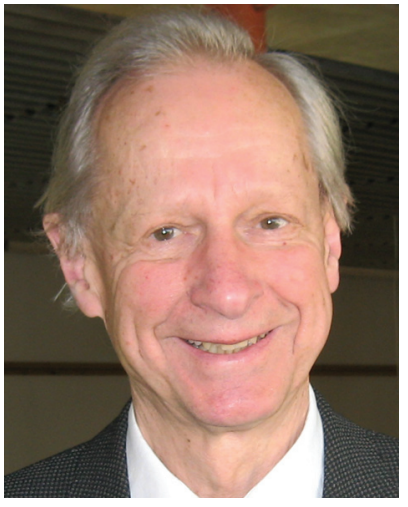

Björn Åkermark
Björn Åkermark is Professor Emeritus in Organic Chemistry at the Royal Institute of Technology, Stockholm, and has, since his retirement, been employed at Stockholm University as Guest Professor and research leader. He received his Ph.D. from the Royal Institute of Technology in 1967 under the direction of Professor Holger Erdtman and Professor Carl-Axel Wachtmeister and became Assistant Professor at the Royal Institute of Technology the same year. During 1967-1968 he was a visiting scholar with Professor Eugen van Tamelen at Stanford University. He then returned to the Royal Institute of Technology where he was promoted to Associate Professor in 1972 and subsequently to Professor in 1980. He has received several prestigious awards, such as the Zorn Fellowship from the Sweden-America Foundation in 1977, the Arrhenius Medal in 1978 and the Bror Holmberg Medal in 2009, both from the Swedish Chemical Society, and Ulla and Stig Holmquist's Prize in 2009 from Uppsala University. His research interest is in the field of homogeneous catalysis and has, since 1989, focused on artificial photosynthesis. 
this could have a widespread impact on the construction of low-cost devices for solar energy to fuel conversion. This Perspective summarizes recent advances in the design of WOCs based on earth-abundant first-row transition metals with an emphasis on homogeneous systems based on Mn, Fe, $\mathrm{Co}$ and $\mathrm{Cu}$. An examination of the advantages and current limitations of the highlighted catalytic systems is also presented, along with potential future directions of this expanding research area.

\section{Methods for evaluating water oxidation catalysts}

There exist essentially three different methods for evaluating whether a complex is capable of oxidizing $\mathrm{H}_{2} \mathrm{O}$. The first method is chemical oxidation and involves the use of sacrificial oxidants, allowing for rapid screening of potential WOCs. The most widely used one-electron oxidant is ceric ammonium nitrate $\left(\mathrm{CAN}, \mathrm{Ce}\left(\mathrm{NH}_{4}\right)_{2}\left(\mathrm{NO}_{3}\right)_{6}, \mathrm{Ce}^{\mathrm{IV}}\right)$, which has a redox potential of $\sim 1.70 \mathrm{~V} v s$. NHE (normal hydrogen electrode). ${ }^{33}$ However, the $\mathrm{O}_{2}$ studies with $\mathrm{Ce}^{\mathrm{IV}}$ (eqn (3)) need to be performed in acidic aqueous media, due to the instability of $\mathrm{Ce}^{\mathrm{IV}}$ at higher $\mathrm{pH}$, and this limits the evaluation to homogeneous catalysts that are resistant to decomposition under acidic conditions: ${ }^{34}$

$$
2 \mathrm{H}_{2} \mathrm{O}+4 \mathrm{Ce}^{\mathrm{IV}} \stackrel{\text { cat. }}{\longrightarrow} \mathrm{O}_{2}+4 \mathrm{H}^{+}+4 \mathrm{Ce}^{\mathrm{III}}
$$

A number of two-electron oxidants have also been used for the evaluation of WOCs, including potassium peroxymonosulfate (Oxone $\left.{ }^{3}\right)^{35}$ and sodium periodate $\left(\mathrm{NaIO}_{4}\right),{ }^{36}$ which have redox potentials of $1.82 \mathrm{~V}$ and $1.60 \mathrm{~V}$ vs. NHE, respectively. ${ }^{37,38}$ The main advantage with these oxidants is that they can be

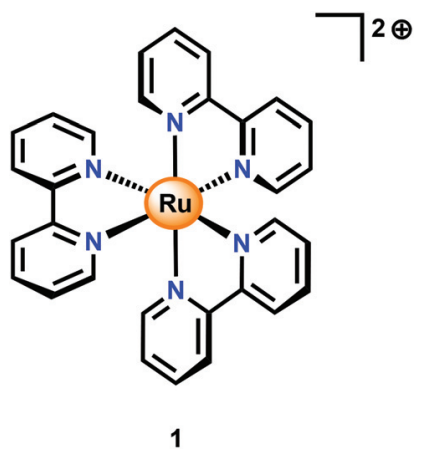

Fig. 3 Structure of $\left[R u(b p y)_{3}\right]^{2+}(1)$. bpy $=2,2^{\prime}$-bipyridine. used under neutral conditions, thus allowing the examination of acid labile catalysts. ${ }^{39}$ The two-electron nature of these oxidants limits their relevance to one-electron conditions, which might occur in photoelectrochemical cells. Oxone® and $\mathrm{NaIO}_{4}$ are also known oxo-transfer reagents, which precludes that both oxygen atoms in the generated $\mathrm{O}_{2}$ originate from $\mathrm{H}_{2} \mathrm{O}$; however, this can be easily determined by mass spectrometry using ${ }^{18} \mathrm{O}$ isotopically labeled $\mathrm{H}_{2} \mathrm{O}\left(\mathrm{H}_{2}{ }^{18} \mathrm{O}\right)$. It should be noted that recent studies on $\mathrm{Ce}^{\mathrm{IV}}$ suggest that this oxidant might also function as an oxo-transfer reagent. ${ }^{40,41}$

An alternative to $\mathrm{Ce}^{\mathrm{IV}}$ is the one-electron oxidant $\left[\mathrm{Ru}(\mathrm{bpy})_{3}\right]^{3+}\left(\mathbf{1}^{+}\right.$, Fig. 3; bpy $=2,2^{\prime}$-bipyridine $)$, which has a redox potential of $1.26 \mathrm{~V} v s$. NHE. Although this and related complexes have not been widely used as oxidants (eqn (4)), perhaps due to their high cost, the advantages of these oxidants are their activity under neutral conditions and the fact that they can be photochemically generated from the corresponding $\left[\mathrm{Ru}(\mathrm{bpy})_{3}\right]^{2+}$-type complexes. ${ }^{42}$ The photochemistry of these $\mathrm{Ru}$ polypyridyl complexes has been extensively studied and their photophysical properties are well documented: ${ }^{43-45}$

$$
2 \mathrm{H}_{2} \mathrm{O}+4\left[\mathrm{Ru}(\text { bpy })_{3}\right]^{3+} \stackrel{\text { cat. }}{\longrightarrow} \mathrm{O}_{2}+4 \mathrm{H}^{+}+4\left[\mathrm{Ru}(\text { bpy })_{3}\right]^{2+}
$$

In combination with a sacrificial electron acceptor, $\left[\mathrm{Ru}(\mathrm{bpy})_{3}\right]^{2+}$ can be used for light-driven $\mathrm{H}_{2} \mathrm{O}$ oxidation. Visiblelight absorption of the $\left[\mathrm{Ru}(\mathrm{bpy})_{3}\right]^{2+}$ photosensitizer results in the formation of the singlet excited state $\left({ }^{1}\left[\mathrm{Ru}(\mathrm{bpy})_{3}\right]^{2+*}\right)$. This undergoes rapid intersystem crossing (ISC) and is converted into an excited triplet state $\left({ }^{3}\left[\mathrm{Ru}(\mathrm{bpy})_{3}\right]^{2+*}\right)$. In the presence of a sacrificial electron acceptor, such as sodium persulfate $\left(\mathrm{Na}_{2} \mathrm{~S}_{2} \mathrm{O}_{8}\right),{ }^{3}\left[\mathrm{Ru}(\mathrm{bpy})_{3}\right]^{2+*}$ is oxidatively quenched, which generates $\left[\mathrm{Ru}(\mathrm{bpy})_{3}\right]^{3+}$, a sulfate ion $\left(\mathrm{SO}_{4}{ }^{2-}\right)$ and a sulfate radical $\left(\mathrm{SO}_{4}{ }^{-*}\right)$. The sulfate radical is a strong oxidant $(E=\sim 2.4 \mathrm{~V} v s$. $\mathrm{NHE}^{46}$ ) and has the ability to directly oxidize another equivalent of $\left[\mathrm{Ru}(\mathrm{bpy})_{3}\right]^{2+}$ to $\left[\mathrm{Ru}(\mathrm{bpy})_{3}\right]^{3+}$. The overall light-induced process is summarized in eqn (5) and Fig. $4 .^{43-45,47}$

$$
\begin{aligned}
2 h \nu & +4\left[\mathrm{Ru}(\text { bpy })_{3}\right]^{2+}+2 \mathrm{~S}_{2} \mathrm{O}_{8}{ }^{2-} \\
& \rightarrow 4\left[\mathrm{Ru}(\text { bpy })_{3}\right]^{3+}+4 \mathrm{SO}_{4}{ }^{2-}
\end{aligned}
$$

In addition to the aforementioned (photo)chemical techniques for studying WOCs, (photo)electrochemical methods are also available. Here, an important parameter is the socalled overpotential, which is the potential that has to be applied in an electrolysis cell in addition to the thermodynamical potential for a given half-reaction. ${ }^{48}$ These electrochemical studies have a major advantage, namely that the studied system resembles the conditions that would be employed in the envisioned formation of solar fuels. ${ }^{49}$

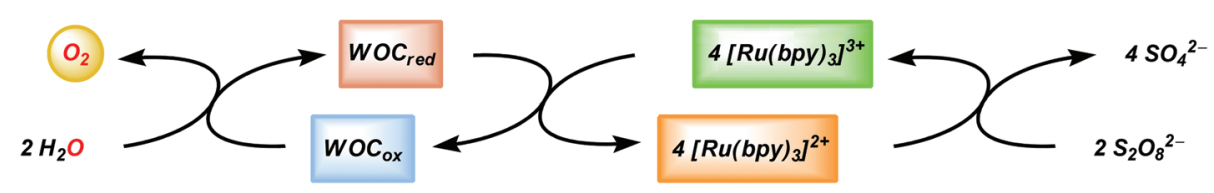

Fig. 4 Three-component system for light-driven $\mathrm{H}_{2} \mathrm{O}$ oxidation. 


\section{Distinguishing between heterogeneous and homogeneous species}

Earth-abundant WOCs are especially prone to undergo irreversible structural modifications, leading to transformation of the initially homogeneous complex into heterogeneous metal oxide species. The designed metal complexes merely act as precursors for the in situ formation of metal nanoparticles that might be the true active catalytic species. An essential element for researchers working in the field is thus to determine whether the observed activity is derived from the pristine metal complex or whether nanoparticles, produced during the oxidation process, are responsible for converting $\mathrm{H}_{2} \mathrm{O}$ to $\mathrm{O}_{2}$. Several distinct physical techniques exist for establishing whether the starting well-defined molecular complex is the true catalytic species or merely a precursor and include X-ray photoelectron spectroscopy (XPS), energy-dispersive X-ray spectroscopy (EDX), transmission electron microscopy (TEM), and dynamic light scattering (DLS). In combination, these techniques provide a powerful toolbox for assessing the real catalytic entity. One also needs to consider that a slight change in the reaction conditions may have a great effect on both the stability of WOCs and the operating mechanism. ${ }^{50,51}$

\section{Artificial Mn complexes as water oxidation catalysts}

\subsection{Dinuclear Mn complexes containing multidentate ligand scaffolds}

Inspired by the $\mathrm{Mn}_{4} \mathrm{Ca}$ cluster located in the OEC, initial attempts to develop earth-abundant WOCs focused on $\mathrm{Mn}^{52}$ One of the seminal examples of dinuclear $\mathrm{Mn}$ complexes capable of oxidizing $\mathrm{H}_{2} \mathrm{O}$ is the $\mathrm{Mn}$ porphyrin dimers 2-4 (Fig. 5) developed by Naruta and co-workers. ${ }^{53,54}$ In aqueous MeCN solutions containing $n \mathrm{Bu}_{4} \mathrm{NOH}$, all three Mn dimers showed a similar irreversible increase in current at potentials $>1.4 \mathrm{~V} v s$. NHE. Of the three studied Mn porphyrin dimers, complex 4 showed the highest activity, affording a TON of 9.2. The $\mathrm{O}_{2}$ evolution rate was also found to be proportional to the concentration of the Mn dimers. The analogous monomeric Mn porphyrin complexes did not promote $\mathrm{O}_{2}$ evolution and in the absence of the Mn dimers the onset potential was observed at $>2.5 \mathrm{~V}$, highlighting the necessity for the dinuclear $\mathrm{Mn}$ scaffold. ${ }^{53}$ Due to the proximity of the Mn centers, the authors proposed that $\mathrm{O}-\mathrm{O}$ bond formation occurred through nucleophilic attack of $\mathrm{OH}^{-}$on a dimeric $\mathrm{Mn}=\mathrm{V}$ species, thus generating a $\mathrm{Mn}^{\mathrm{IV}}-\mathrm{OO}-\mathrm{Mn}^{\mathrm{IV}}$ species from which $\mathrm{O}_{2}$ could subsequently be liberated. ${ }^{54} \mathrm{~A}$ sulfonated $\mathrm{Mn}$ porphyrin complex has also been incorporated into a thin layer of poly(terthiophene) (PTTh) for attachment to indium tin oxide (ITO) electrodes. The resulting electrodes were capable of catalyzing photoelectrochemical $\mathrm{H}_{2} \mathrm{O}$ oxidation with low overpotentials. $^{55}$

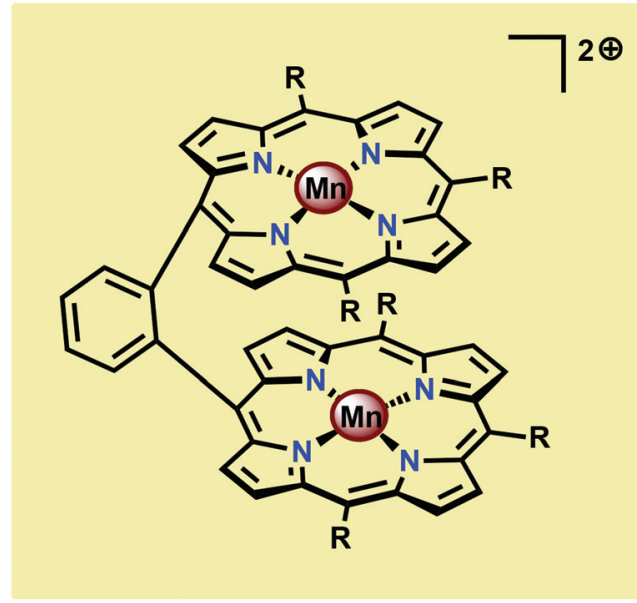

$$
\begin{aligned}
& \text { 2: } \mathrm{R}=4-{ }^{t} \mathrm{BuC}_{6} \mathrm{H}_{4} \\
& \text { 3: } \mathrm{R}=2,4,6-(\mathrm{Me})_{3} \mathrm{C}_{6} \mathrm{H}_{2} \\
& \text { 4: } \mathrm{R}=\mathrm{C}_{6} \mathrm{~F}_{5}
\end{aligned}
$$

Fig. 5 Mn porphyrin dimers $2-4$.

Perhaps the most well-studied Mn complex capable of mediating $\mathrm{H}_{2} \mathrm{O}$ oxidation is the dimeric $\left[(\mathrm{tpy})\left(\mathrm{OH}_{2}\right) \mathrm{Mn}\right.$ $(\mu-\mathrm{O})_{2} \mathrm{Mn}\left(\mathrm{OH}_{2}\right)($ tpy $\left.)\right]^{3+}$ complex $\left(5\right.$, Fig. 6 ; tpy $=2,2^{\prime}: 6^{\prime}, 2^{\prime \prime}$-terpyridine) reported by Crabtree's and Brudvig's groups. ${ }^{35,56,57}$ The crystal structure of the dinuclear Mn complex 5 revealed that it consisted of a mixed valence dimer with one of the Mn centers being in the $+_{\text {III }}$ state and the other in the $+_{\text {IV }}$ state. The two exchangeable aqua ligands are essential for the catalytic activity of the Mn complex. The initial evaluation of the oxidation capability of the complex was carried out with $\mathrm{NaOCl}$ as a chemical oxidant. Using this oxidant at $\mathrm{pH}$ 8.6, the dimeric Mn complex 5 afforded a TON of 4 and a TOF of $0.0033 \mathrm{~s}^{-1}$. The low efficiency of the Mn dimer was ascribed to the ligand decomposition, resulting in the formation of catalytically active $\mathrm{MnO}_{4}{ }^{-}$, as monitored by UV-vis spectroscopy. ${ }^{35}$ Studies have also suggested that $\mathrm{H}_{2} \mathrm{O}$ oxidation with Mn complex 5 can be driven using Oxone $\AA^{58,59}$ or $\mathrm{Ce}^{\mathrm{IV}}$ (ref. 60 and 61) as a

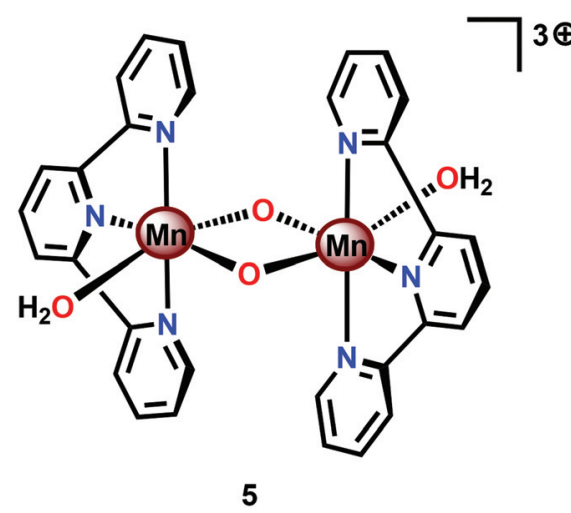

Fig. 6 Structure of the dimeric $\mathrm{Mn}_{2}^{\text {III,IV }}$ complex [(terpy) $\left(\mathrm{OH}_{2}\right) \mathrm{Mn}(\mu-\mathrm{O})_{2}$ $\mathrm{Mn}\left(\mathrm{OH}_{2}\right)(\text { terpy) }]^{3+}(5)$. 
chemical oxidant. Deposition of the dimeric Mn complex 5 onto different materials, such as kaolin, ${ }^{62}$ mica, ${ }^{63-65}$ montmorillonite ${ }^{66}$ or $\mathrm{TiO}_{2},{ }^{67,68}$ has also been carried out. Additionally, attempts to extend the lifetime of Mn complex 5 by its incorporation into metal-organic frameworks (MOFs) have been reported. ${ }^{69,70}$ A variety of analogs of Mn complex 5 have been synthesized and evaluated as WOCs. ${ }^{71-75}$

Based on UV-vis spectroscopy and electron paramagnetic resonance (EPR) experiments, the authors proposed a simplified mechanism, depicted in Scheme 1, for $\mathrm{O}_{2}$ formation from the reaction of $\mathrm{Mn}$ complex 5 with $\mathrm{NaClO}$. The proposed mechanism involves an initial oxidation of dimeric Mn complex 5 to produce a $\mathrm{Mn}_{2}^{\mathrm{IV}, \mathrm{IV}}$ species (6), which can react with the oxidant to generate $\mathrm{Mn}^{\mathrm{V}}=\mathrm{O}(7)$. This species is the key intermediate and is responsible for promoting $\mathrm{O}-\mathrm{O}$ bond formation via nucleophilic attack of $\mathrm{OH}^{-}$. The formed Mn-peroxo intermediate is subsequently oxidized, which results in the release of $\mathrm{O}_{2}$ and ultimately regenerates the dimeric $\mathrm{Mn}_{2}^{\mathrm{IV}, \mathrm{IV}}$ complex $6 .^{35,76}$ It can be concluded that the mechanism by which Mn complex 5 mediates the oxidation of $\mathrm{H}_{2} \mathrm{O}$ is intricate and is highly dependent on the reaction conditions. $^{77,78}$ This is further supported by findings concerning the possible involvement of a tetrameric $\mathrm{Mn}$ species $^{79-81}$ while another report suggests that heterogeneous Mn-oxides are generated. ${ }^{82}$
Based on previous findings, ${ }^{83}$ McKenzie and co-workers evaluated the dimeric Mn complex $\left[\mathrm{Mn}_{2}^{\mathrm{II}, \mathrm{II}}(\operatorname{mcbpen})_{2}\left(\mathrm{OH}_{2}\right)_{2}\right]^{2+}$ (9; mcbpen $=N$-methyl- $N^{\prime}$-carboxymethyl- $N, N^{\prime}$-bis(2-pyridylmethyl)ethane-1,2-diamine) as a WOC (Fig. 7). The dimeric Mn complex 9 was able to evolve $\mathrm{O}_{2}$ when driven using ${ }^{t} \mathrm{BuOOH}$ or $\mathrm{Ce}^{\mathrm{IV}}$ as a chemical oxidant. ${ }^{84} \mathrm{Using}^{t} \mathrm{BuOOH}$ as an oxidant afforded high turnovers of up to $15000 \mathrm{~mol}$ of $\mathrm{O}_{2}$ per

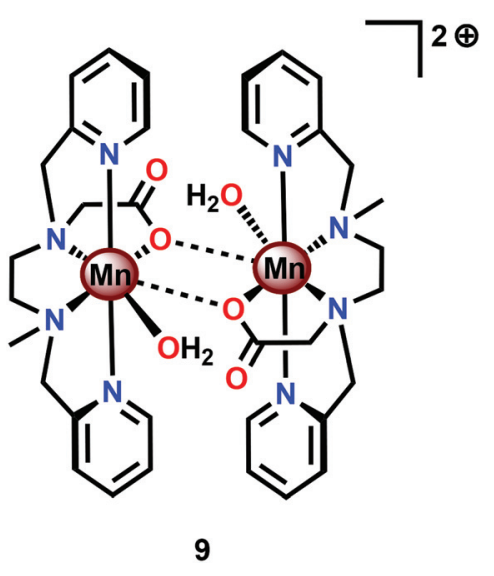

Fig. 7 Structure of the dimeric $M n_{2}^{\|, \prime \prime}$ complex $\left[\mathrm{Mn}_{2}^{\|, \prime \prime}(\mathrm{mcbpen})_{2}\right.$ $\left.\left(\mathrm{OH}_{2}\right)_{2}\right]^{2+}(9)$.

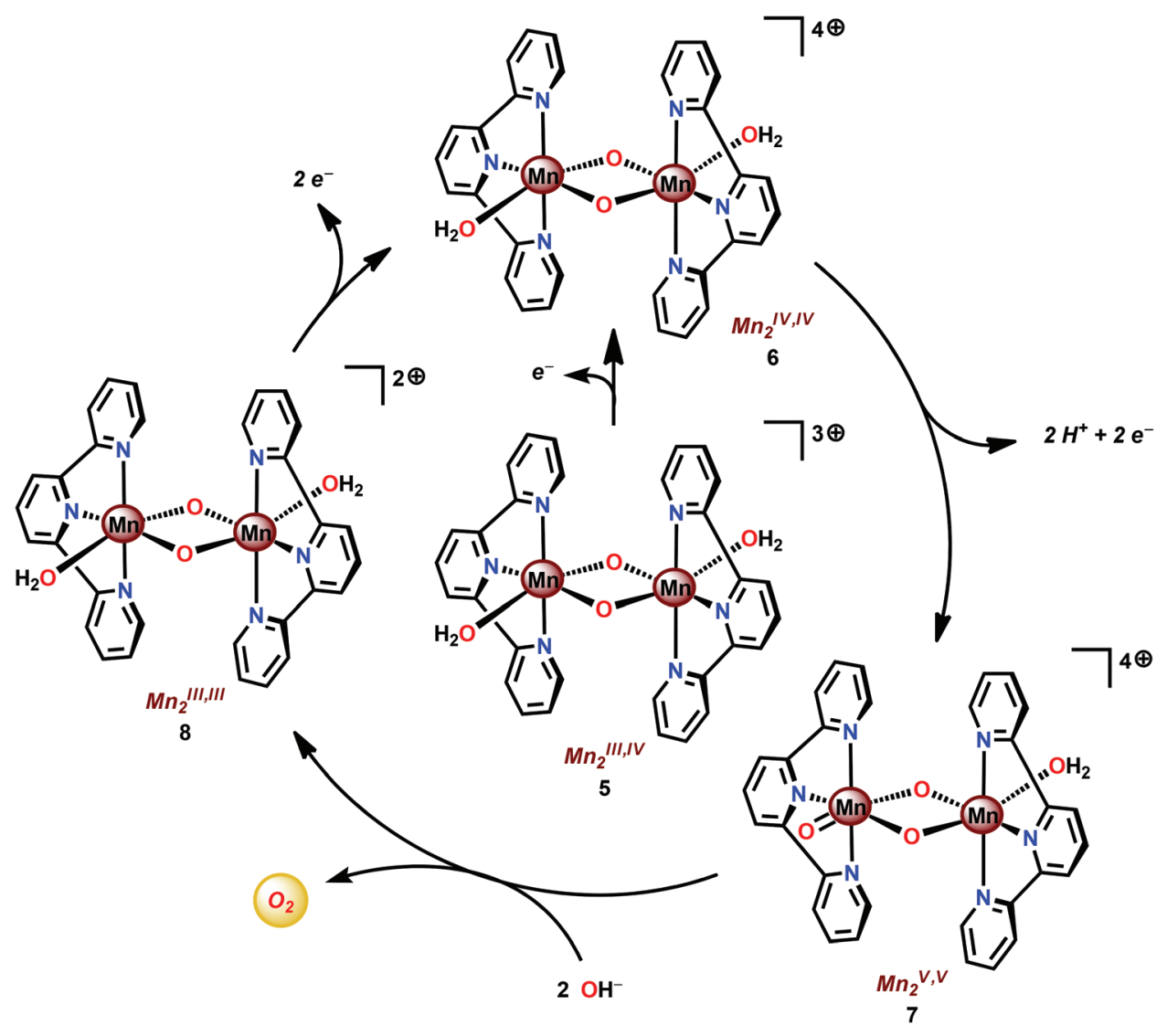

Scheme 1 Simplified proposed mechanism for $\mathrm{H}_{2} \mathrm{O}$ oxidation by $\mathrm{Mn}_{2}^{\text {III,IV }}$ complex 5 . 
mol of $\mathrm{Mn} .{ }^{85}$ However, when using isotopically labeled $\mathrm{H}_{2} \mathrm{O}$ $\left(\mathrm{H}_{2}{ }^{18} \mathrm{O}\right)$, the evolved $\mathrm{O}_{2}$ was shown to be exclusively ${ }^{34} \mathrm{O}_{2}$. This highlights that one of the oxygen atoms in the generated $\mathrm{O}_{2}$ originates from the ${ }^{t} \mathrm{BuOOH}$ oxidant, demonstrating the ability of this two-electron oxidant to act as an oxygen atom transfer reagent. In the case when $\mathrm{Ce}^{\mathrm{IV}}$ is used as an oxidant, the only available source of oxygen is the nitrate counterion of the oxidant, thus suggesting the active involvement of the nitrate counterion in the catalytic cycle. ${ }^{84}$

The mcbpen ligand scaffold with its carboxylate and pyridine motifs attached to the ethylenediamine backbone was suggested to provide an ideal environment for coordination to $\mathrm{Mn}$ in various redox states. It was initially proposed that the catalytic cycle for $\mathrm{O}_{2}$ generation involved the coupling of two $\mu$-oxo units. $^{84}$ However, a subsequent computational study suggested that the key species consisted of a $\mathrm{Mn}^{\mathrm{III}}(\mu-\mathrm{O}) \mathrm{Mn}^{\mathrm{IV}}$ $\mathrm{O}^{\bullet}$ species (12), a mixed valent oxyl radical species, which is in equilibrium with the isomeric diamond-core $\mathrm{Mn}^{\mathrm{IV}}(\mu-\mathrm{O})_{2} \mathrm{Mn}^{\mathrm{IV}}$ (13). This mixed valent $\mathrm{Mn}^{\mathrm{III}}(\mu-\mathrm{O}) \mathrm{Mn}^{\mathrm{IV}}-\mathrm{O}^{\cdot}$ species (12) is responsible for mediating $\mathrm{O}-\mathrm{O}$ bond formation through nucleophilic attack of $\mathrm{H}_{2} \mathrm{O}$, resulting in a $\mathrm{Mn}^{\mathrm{III}}-\mathrm{OOH}$ species (14). The other Mn center, which has thus far acted as a spectator, functions as the additional oxidizing equivalent, liberating $\mathrm{O}_{2}$ to regenerate the monomeric $\mathrm{Mn}^{\mathrm{II}}$ complex 10 without the need for an additional oxidation event (Scheme 2). ${ }^{86}$
Several Mn complexes have been covalently linked to $\left[\mathrm{Ru}(\mathrm{bpy})_{3}\right]^{2+}$-type chromophores for mimicking the electron transfer events occurring in Photosystem II. Light absorption of the $\mathrm{Ru}^{\mathrm{II}}$ photosensitizer core triggers electron transfer from the photoexcited state $\left(\mathrm{Ru}^{2+}\right)$ to a sacrificial electron transfer. The oxidized photosensitizer subsequently abstracts an electron from the attached $\mathrm{Mn}$ complex. ${ }^{87-92}$ Of the examined $\mathrm{Ru}-\mathrm{Mn}$ assemblies, assembly 16 (Fig. 8) displayed promising properties as it was able to undergo three consecutive electron transfers, which converted the initial $\mathrm{Mn}_{2}^{\text {II,II }}$ core to $\mathrm{Mn}_{2}^{\mathrm{III}, \mathrm{IV}}$. Although $\mathrm{Ru}-\mathrm{Mn}_{2}$ assembly could accumulate three oxidizing equivalents, it was not able to evolve $\mathrm{O}_{2}$ under the studied reaction conditions. ${ }^{93}$

In light of the attractive features of the dinuclear Mn core in assembly 16, the properties and $\mathrm{O}_{2}$ evolving activities of several different dinuclear Mn complexes (17-20) housing ligand scaffolds based on benzylic amines have been studied (Fig. 9). ${ }^{61 c, 94-98}$ It could be concluded that the one-electron oxidants $\mathrm{Ce}^{\mathrm{IV}}$ and $\left[\mathrm{Ru}(\mathrm{bpy})_{3}\right]^{3+}$ were inefficient oxidants in $\mathrm{H}_{2} \mathrm{O}$ oxidation. However, with two-electron oxidants, such as $\mathrm{H}_{2} \mathrm{O}_{2}$, ${ }^{t} \mathrm{BuOOH}$, Oxone ${ }^{\circledR}$ or $\mathrm{NaClO}$, i.e. oxygen-transfer oxidants, a more efficient $\mathrm{O}_{2}$ evolution was observed. ${ }^{61 c, 96}$

The fact that imidazole, carboxylate and phenol moieties are essential features of the OEC inspired the group of Åkermark to design the dinuclear Mn complex 21 (Fig. 10, left)

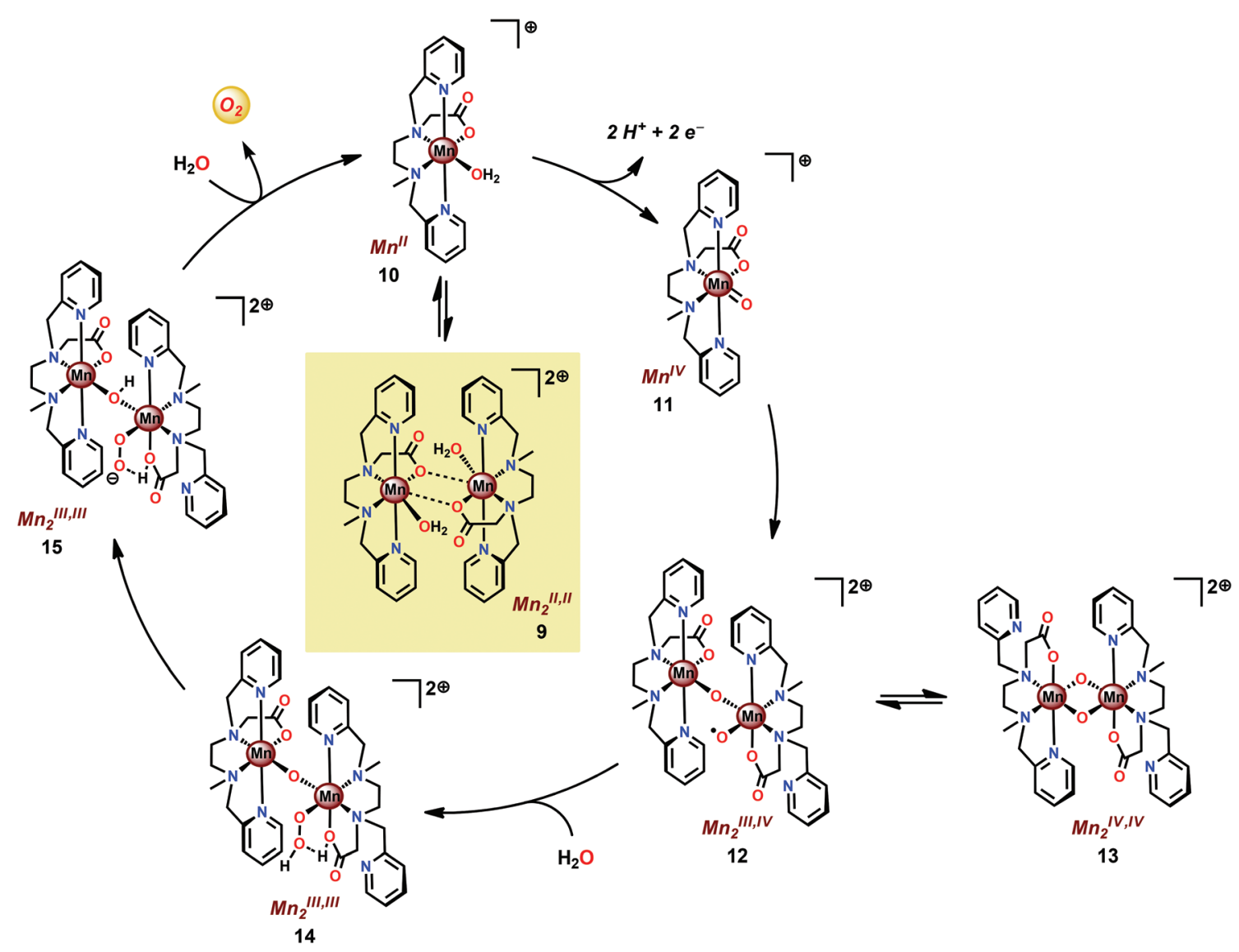

Scheme 2 Proposed mechanism for $\mathrm{O}_{2}$ evolution catalyzed by the $\left[\mathrm{Mn} n^{11,11}(\mathrm{mcbpen})_{2}\left(\mathrm{OH}_{2}\right)_{2}\right]^{2+}$ complex 9 . 


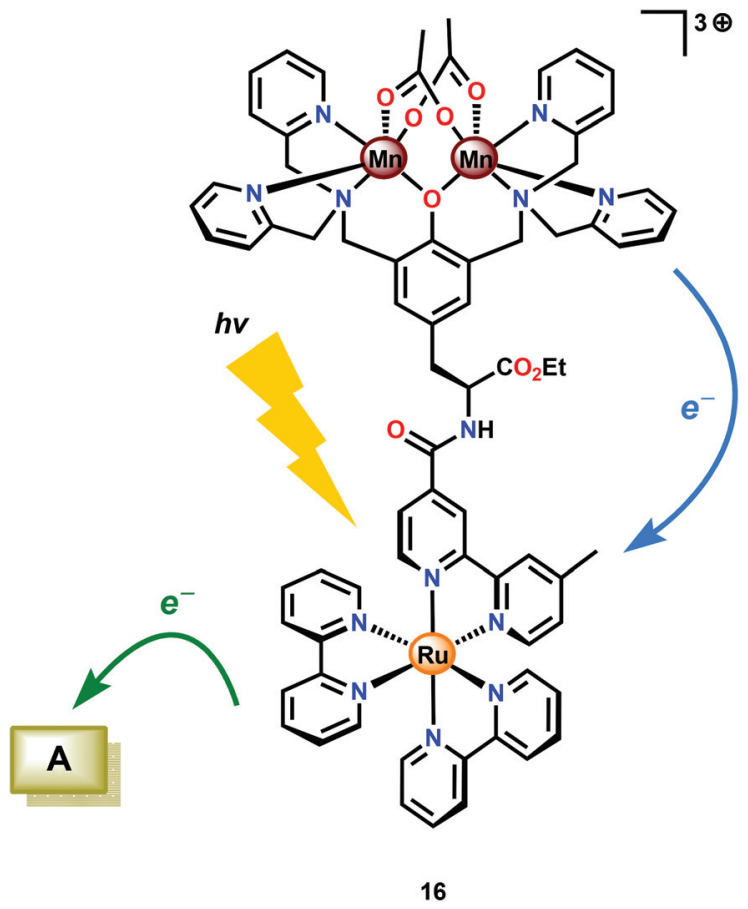

Fig. $8 \mathrm{Ru}-\mathrm{Mn}_{2}$ assembly 16 capable of accumulating three oxidizing equivalents. $\mathrm{A}=$ acceptor. housing a bioinspired ligand scaffold with imidazole, carboxylate and phenolic groups. ${ }^{99}$ In the solid state, the crystal structure revealed that $\mathrm{Mn}$ complex 21 adopts a tetrameric structure (22, Fig. 10, right), resembling the tetranuclear $\mathrm{Mn}_{4} \mathrm{Ca}$ core in the OEC. An additional advantage of the incorporation of the negatively charged groups was the lowering of the redox potentials, an effect previously observed for other metal complexes, ${ }^{100,101}$ allowing for $\mathrm{H}_{2} \mathrm{O}$ oxidation to be driven by $\left[\mathrm{Ru}(\mathrm{bpy})_{3}\right]^{3+}$. Experiments were initially carried out with a 480 fold excess of the chemical oxidant $\left[\mathrm{Ru}(\mathrm{bpy})_{3}\right]^{3+}$ under neutral conditions. Upon addition of an aqueous solution containing Mn complex 21, $\mathrm{O}_{2}$ evolution was immediately observed, affording a TON of $\sim 25$ and a TOF of $\sim 0.027 \mathrm{~s}^{-1}$. Light-driven $\mathrm{H}_{2} \mathrm{O}$ oxidation was also carried out using $\left[\mathrm{Ru}(\mathrm{bpy})_{3}\right]^{2+}$-type photosensitizers and $\mathrm{Na}_{2} \mathrm{~S}_{2} \mathrm{O}_{8}$ as a sacrificial electron acceptor. When employing $\left[\mathrm{Ru}(\mathrm{bpy})_{2}(\mathrm{deeb})\right]^{2+}$ as a photosensitizer (deeb = diethyl 2,2'-bipyridine-4,4'-dicarboxylate), a TON of 4 was reached. Experiments with isotopically labeled $\mathrm{H}_{2} \mathrm{O}$ $\left(\mathrm{H}_{2}{ }^{18} \mathrm{O}\right)$ confirmed that both of the oxygen atoms in the produced $\mathrm{O}_{2}$ originated from the solvent $\mathrm{H}_{2} \mathrm{O} .{ }^{99}$

Subsequent work involved the preparation of a $\mathrm{Ru}-\mathrm{Mn}_{2}$ assembly (23, Fig. 11) where the dinuclear $\mathrm{Mn}_{2}^{\text {II,III }}$ complex 21 was covalently linked to a $\left[\mathrm{Ru}(\mathrm{bpy})_{3}\right]^{2+}$-type photosensitizer. ${ }^{102}$ Although $\mathrm{Ru}-\mathrm{Mn}_{2}$ assembly 23 was able to mediate chemical

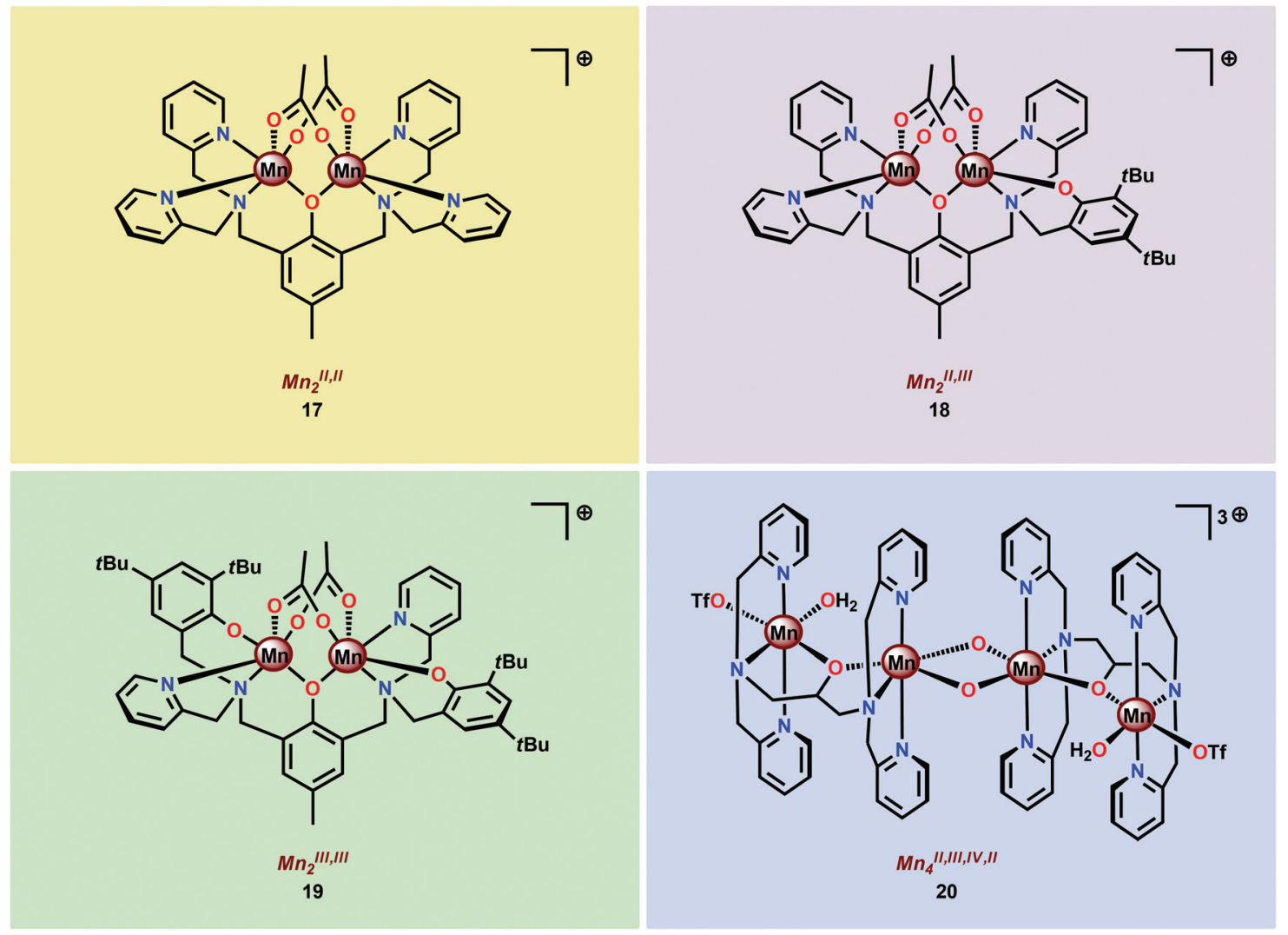

Fig. 9 Structures of $\mathrm{Mn}$ complexes 17-20. 

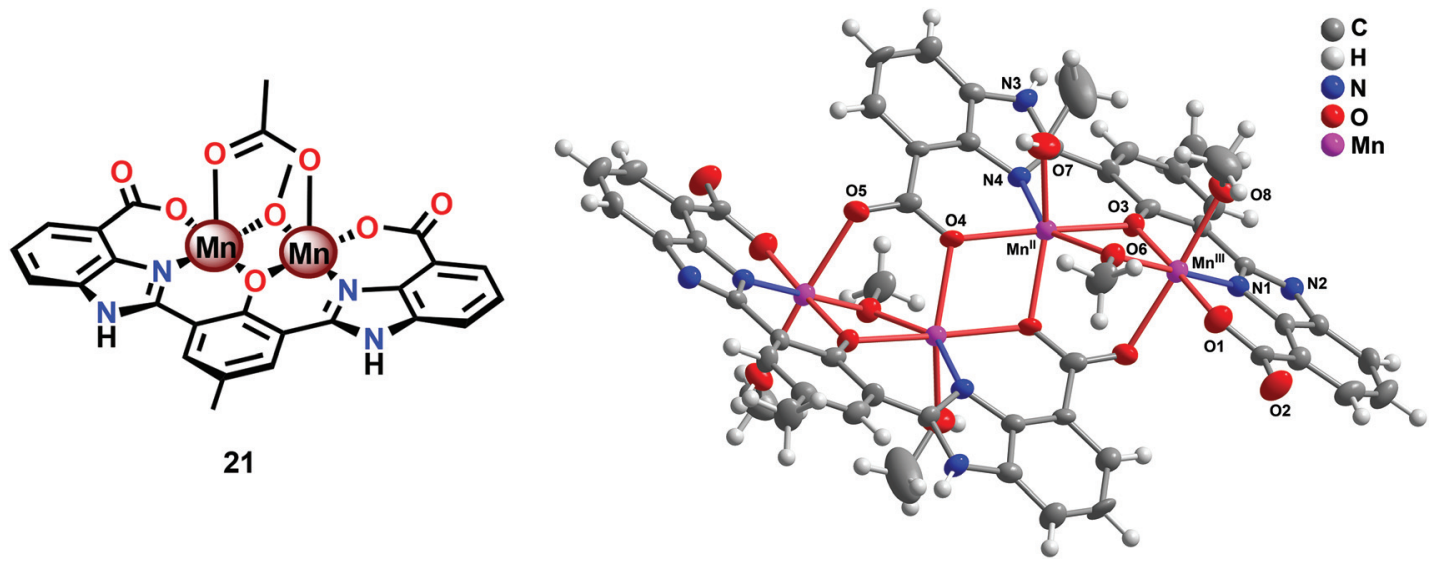

Fig. 10 (Left) Molecular structure of the dinuclear $\mathrm{Mn}_{2}^{\prime \prime \prime \prime I I ~ c o m p l e x ~} 21$ and (right) crystal structure of the tetranuclear Mn species $22 \mathrm{generated} \mathrm{from}$ complex 21 (reprinted with permission from ref. 104. Copyright 2015 American Chemical Society).

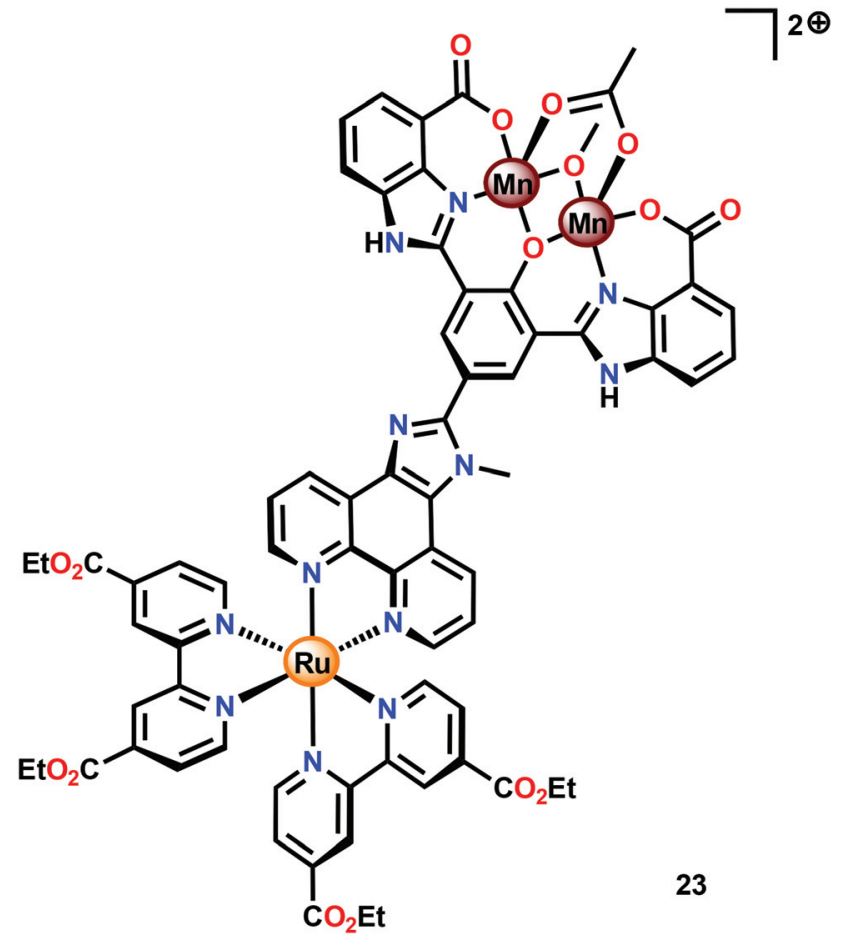

Fig. 11 Structure of Ru-Mn assembly 23.

oxidation of $\mathrm{H}_{2} \mathrm{O}$, the photophysical properties of the assembly did not allow for photochemical $\mathrm{H}_{2} \mathrm{O}$ oxidation in the presence of a sacrificial electron acceptor $\left(\mathrm{Na}_{2} \mathrm{~S}_{2} \mathrm{O}_{8}\right)$. It was revealed that the excited state of the dyad $\mathbf{2 3}$ was too short-lived and could not be modelled with a mono-exponential decay function. Computational studies suggested the presence of an intricate excited-state manifold, along with possible large effects of different protonation states, which may have contributed to the observed intricate decay pattern.

A series of dinuclear derivatives of Mn complex 21 have also been synthesized. ${ }^{103}$ The prepared ligand scaffolds contained a variety of different substituents and the electronic and catalytic features of the corresponding Mn complexes were systematically examined. Of the synthesized Mn complexes, complex 24 possessing the distal carboxylate group (Fig. 12, left) was shown to produce $\mathrm{O}_{2}$ more efficiently than the other Mn complexes. This effect was proposed to originate from pre-orientation of the incoming $\mathrm{H}_{2} \mathrm{O}$ molecule where the introduced carboxylate moiety directs the incoming $\mathrm{H}_{2} \mathrm{O}$ through hydrogen bonding (Fig. 12, right). This probably facilitates protoncoupled electron transfer (PCET) and assists the nucleophilic attack on a high-valent $\mathrm{Mn}$-oxyl/Mn-oxo species. Incorporation of non-innocent distal groups into ligand backbones could be a general method for enhancing the catalytic activity of WOCs.

A computational study has been performed on the mechanism by which the dinuclear $\mathrm{Mn}_{2}^{\mathrm{II}, \mathrm{III}}$ complex 21 mediates $\mathrm{O}-\mathrm{O}$ bond formation. ${ }^{104}$ The study suggested an OEC-like mechanism where tetrameric $\mathrm{Mn}$ species are involved throughout the catalytic cycle (Fig. 13). The catalytic cycle was suggested to begin with the formal $\mathrm{Mn}_{4}^{\text {III,III,III,IV }}$ species, which is better described as having all four Mn centers in the +III state with a ligand radical. Four PCET events

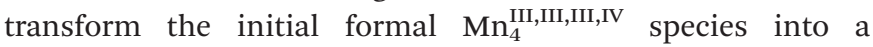
$\mathrm{Mn}_{4}^{\mathrm{III}, \mathrm{IV}, \mathrm{IV}, \mathrm{IV}}-\mathrm{L}^{\cdot}-\mathrm{L}^{\cdot}$ species. Intramolecular proton transfer subsequently generates a $\mathrm{Mn}^{\mathrm{IV}}$-bound oxyl radical that is responsible for creating the $\mathrm{O}-\mathrm{O}$ bond with the $\mathrm{Mn} 1-\mathrm{Mn} 2$ bridging oxo group (Fig. 13). The proposed mechanistic pathway contains several features that are important clues to understand how the OEC catalyzes $\mathrm{H}_{2} \mathrm{O}$ oxidation. ${ }^{19}$ Examples of design principles that were obtained from the study are: (1) a Mnbound terminal aqua molecule is essential for the formation of the crucial $\mathrm{Mn}^{\mathrm{IV}}-\mathrm{O}^{\bullet}$ species, (2) nucleophilic attack on the $\mathrm{Mn}^{\mathrm{IV}}-\mathrm{O}^{\cdot}$ species is less favorable compared to a route featuring the coupling between this species and a bridging oxo moiety, and (3) the presence of a redox-active ligand backbone decreases the redox potentials for the individual redox events and alleviates the metal centers from being too heavily oxidized. ${ }^{104}$ 

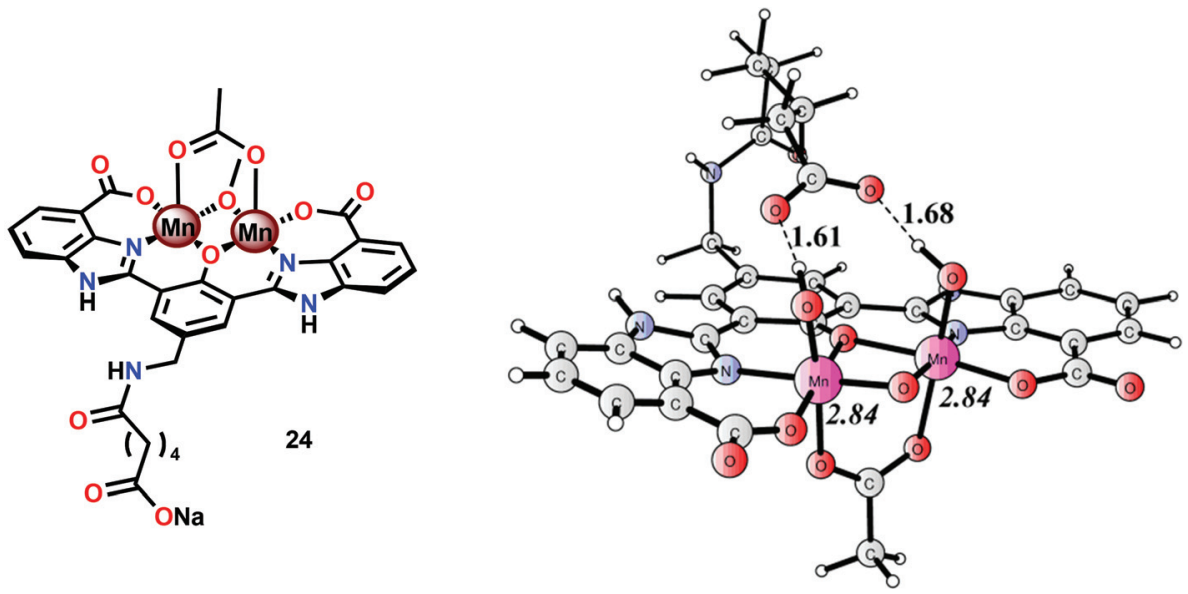

Fig. 12 (Left) Molecular structure of dinuclear $\mathrm{Mn}_{2}^{\mathrm{IIIII}}$ complex 24 and (right) calculated structure of the complex in its formal $\mathrm{Mn}{ }_{2}^{\mathrm{IV}, \mathrm{V}}$ state, showing the hydrogen-bonding interaction between the distal carboxylate moiety and the $\mathrm{Mn}$ bound hydroxide(s) (adapted with permission from ref. 103. Published by the PCCP Owner Societies).
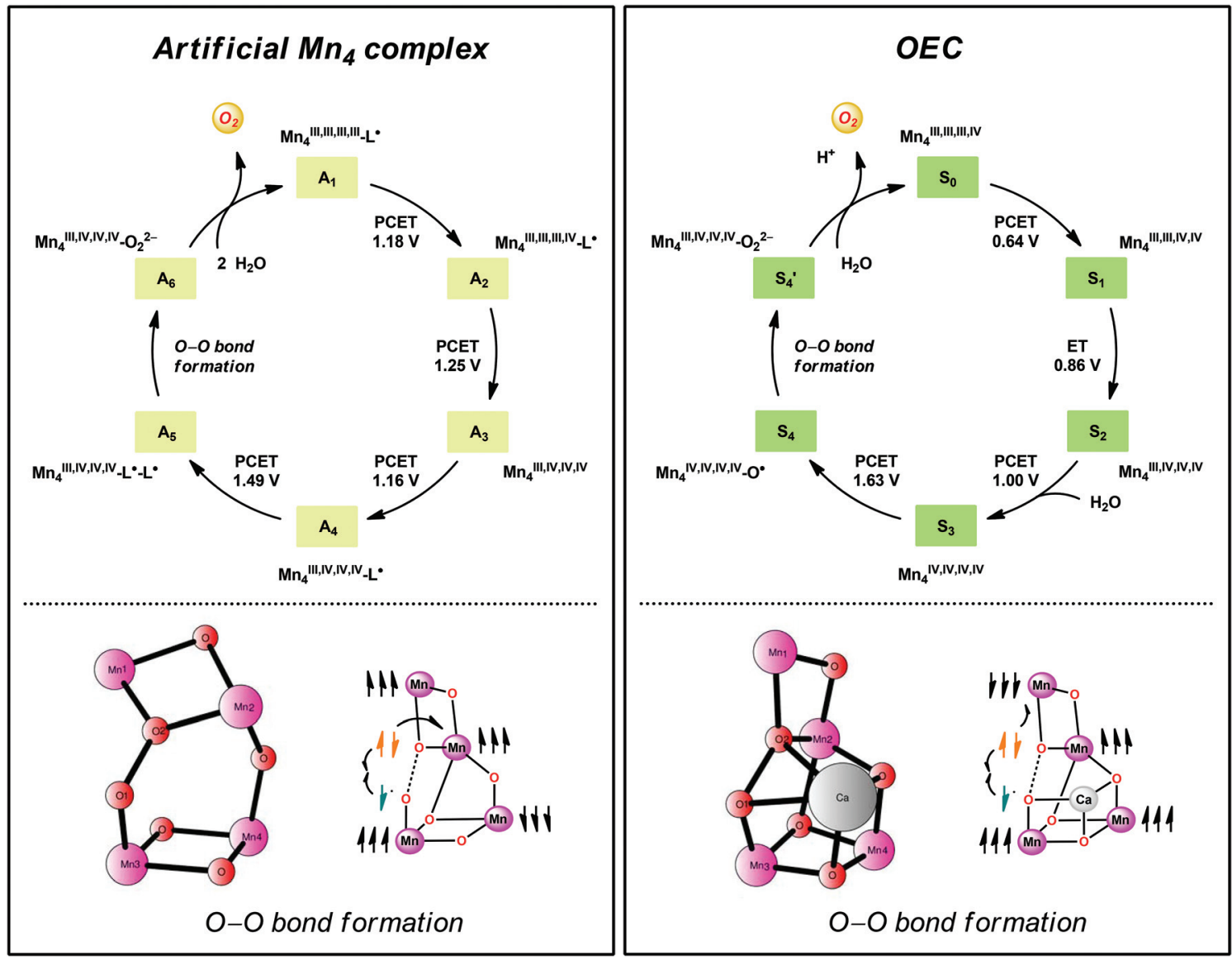

Fig. 13 Comparison of the catalytic cycles and transition-states for $\mathrm{O}-\mathrm{O}$ bond formation for the tetranuclear Mn complex derived from $\mathrm{Mn}$ complex 21 and the tetranuclear $\mathrm{Mn}_{4} \mathrm{Ca}$ cluster in the OEC. Adapted with permission from ref. 104. Copyright 2015 American Chemical Society.

\subsection{Mononuclear Mn complexes: $\mathrm{O}-\mathrm{O}$ bond formation at} single metal centers

A vital feature for metal complexes to mediate $\mathrm{H}_{2} \mathrm{O}$ oxidation is the necessity for these catalysts to generate high-valent metal- oxyl/oxo intermediates, which subsequently trigger $\mathrm{O}-\mathrm{O}$ bond formation. Several formal high-valent Mn-oxo complexes have been prepared using various chemical oxidants, such as hydrogen peroxide $\left(\mathrm{H}_{2} \mathrm{O}_{2}\right),{ }^{105}$ iodosylbenzene (PhIO), ${ }^{106}$ or $m$-chloroperbenzoic acid ( $m$-CPBA $),{ }^{107}$ or photochemically generated $\left[\mathrm{Ru}(\mathrm{bpy})_{3}\right]^{3+} \cdot{ }^{308}$ 
Although a variety of high-valent Mn-oxo complexes have been prepared, ${ }^{109}$ only a few mononuclear Mn complexes have been reported to mediate $\mathrm{H}_{2} \mathrm{O}$ oxidation. An early example of a mononuclear $\mathrm{Mn}$ complex capable of evolving $\mathrm{O}_{2}$ is the $\mathrm{Mn}$ Schiff base complex $\left[\mathrm{Mn}(\mathrm{salpd})\left(\mathrm{OH}_{2}\right)\right]^{+}\left(25\right.$, Fig. 14; $\mathrm{H}_{2}$ salpd $=$ $N, N^{\prime}$-bis(salicylidene)propane-1,3-diamine). This $\mathrm{Mn}^{\text {III }}$ Schiff base complex was reported to liberate $\mathrm{O}_{2}$ and reduce $p$-benzoquinone to hydroquinone when irradiated with visible-light. The catalytic activity was shown to be dependent on the quinone concentration, the wavelength of light, temperature and $\mathrm{pH}$, affording TONs of 0.02-0.06 depending on the reaction conditions. Although the exact mechanism has not been elucidated, the rate of $\mathrm{O}_{2}$ evolution followed first-order kinetics with respect to $\mathrm{Mn}$ complex 25 and $\left[\{\mathrm{Mn}(\text { salpd })\}_{2} \mathrm{O}\right]$ was identified as a deposit during irradiation. ${ }^{110}$ Related Mn Schiff base complexes have also been studied for $\mathrm{O}_{2}$ evolution by several research groups. ${ }^{111-117}$

An interesting study was conducted by the group of Åkermark and Sun where the mononuclear $\mathrm{Mn}^{\mathrm{IV}}$ corrole xanthene complex 26 (Fig. 15) was shown to promote electrochemical $\mathrm{H}_{2} \mathrm{O}$ oxidation. ${ }^{118}$ In aqueous solutions in the presence of $n \mathrm{Bu}_{4} \mathrm{NOH}, \mathrm{O}_{2}$ was detected at quite low oxidation potentials. Electrochemical measurements of Mn corrole complex 26 further revealed that high-valent redox states were accessed at relatively low potentials. A computational study suggested that

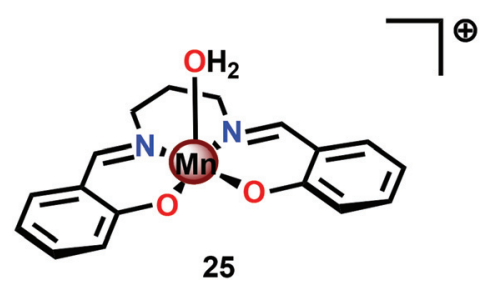

Fig. 14 Structure of $\mathrm{Mn}$ Schiff base complex $\left[\mathrm{Mn}(\mathrm{salpd})\left(\mathrm{OH}_{2}\right)\right]^{+} 25$.

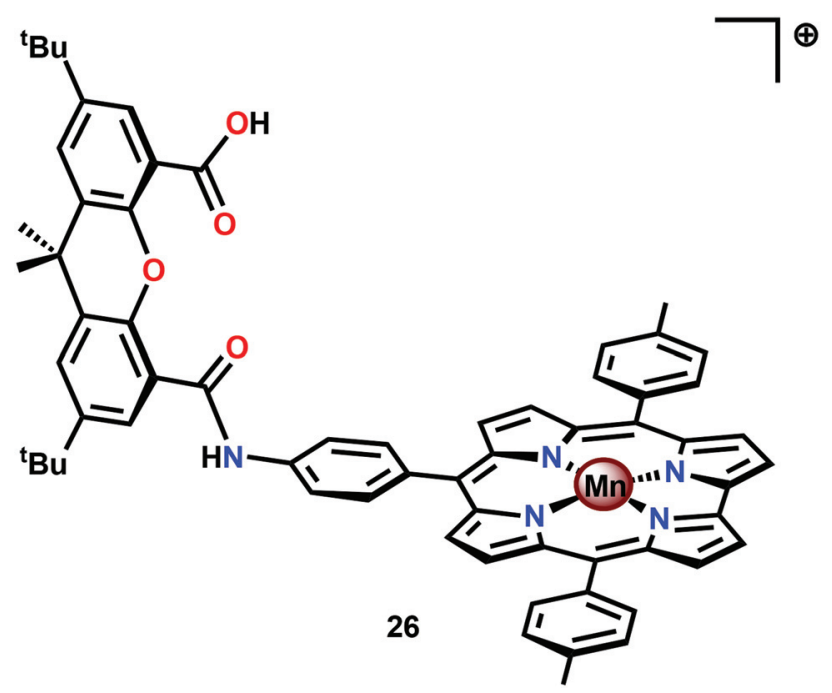

Fig. 15 Structure of mononuclear Mn ${ }^{\text {III }}$ corrole xanthene complex 26.
$\mathrm{O}-\mathrm{O}$ bond formation occurred via nucleophilic attack of $\mathrm{OH}^{-}$ or $\mathrm{H}_{2} \mathrm{O}$ on a formal $\mathrm{Mn}^{\mathrm{V}}=\mathrm{O}$ intermediate. ${ }^{119}$

In attempts to obtain experimental support for a mechanistic pathway involving nucleophilic addition of $\mathrm{OH}^{-}$or $\mathrm{H}_{2} \mathrm{O}$, a subsequent study focused on $\mathrm{Mn}^{\mathrm{III}}$ corrole 27 (Fig. 16). ${ }^{120}$ The Mn corrole complex 27 was chosen as it was believed to produce a sufficiently stable $\mathrm{Mn}^{\mathrm{V}}$ species (28). Treating $\mathrm{Mn}$ complex 27 with ${ }^{t} \mathrm{BuOOH}$ furnished the corresponding $\mathrm{Mn}^{\mathrm{V}}$ species, as shown by UV-vis spectroscopy. Additional support for the generation of the $\mathrm{Mn}^{\mathrm{V}}=\mathrm{O}$ species 28 was obtained from high-resolution mass spectrometry (HRMS). Upon addition of 2 equivalents of $n \mathrm{Bu}_{4} \mathrm{OH}$, rapid $\mathrm{O}_{2}$ evolution ensued and a peak ascribed to a $\mathrm{Mn}^{\mathrm{IV}}$ species (30) appeared, which is most likely generated from oxidation of the $\mathrm{Mn}^{\mathrm{III}}$ hydroperoxo species 29. This peak gradually decreased with the emergence of a peak corresponding to the $\mathrm{Mn}^{\mathrm{III}}-\mathrm{OH}$ complex 31. The use of isotopically labeled $\mathrm{H}_{2} \mathrm{O}\left(\mathrm{H}_{2}{ }^{18} \mathrm{O}\right)$ supported that the evolved $\mathrm{O}_{2}$ is produced by addition of ${ }^{18} \mathrm{O}$ to the unlabeled $\mathrm{Mn}^{\mathrm{V}}=\mathrm{O}$ species. This study demonstrates that nucleophilic attack of hydroxide on a high-valent Mn species is a viable mechanistic scenario for triggering $\mathrm{O}-\mathrm{O}$ bond formation in the conversion of $\mathrm{H}_{2} \mathrm{O}$ to $\mathrm{O}_{2}$ (Scheme 3).

The group of Smith found that small changes in the ligand backbone of $\mathrm{Mn}^{\mathrm{II}}$ pyridinophane complexes (Fig. 17) had a dramatic influence on the catalytic properties of these complexes. ${ }^{121}$ Mn complexes 32 and 33, possessing small substituents, were shown to disproportionate $\mathrm{H}_{2} \mathrm{O}_{2}$ in aqueous solutions. ${ }^{122}$ However, for Mn complex 34 with the sterically encumbered $t \mathrm{Bu}$ group, catalase activity is turned off and the complex instead mediates electrocatalytic $\mathrm{H}_{2} \mathrm{O}$ oxidation. When carrying out the electrocatalytic experiments at $\mathrm{pH} 12.2$ with a potential of $1.23 \mathrm{~V}$ vs. NHE, TONs of 16-24 were obtained with Faradaic efficiencies of $74-81 \%$. A number of experiments were also undertaken to exclude the involvement of heterogeneous nanoparticles: (1) no spectral changes were observed for the electrolysis solutions, (2) DLS measurements provided no evidence for nanoparticles, (3) the catalytic current does not increase over successive scans, which would be expected if a catalytic deposit was produced, and (4) EDX measurements showed no evidence of the formation of $\mathrm{Mn}$ containing deposits on the electrode. Collectively, these results point to a homogeneous pathway for the oxidation of $\mathrm{H}_{2} \mathrm{O}$. Mechanistic studies revealed that the catalytic current varies

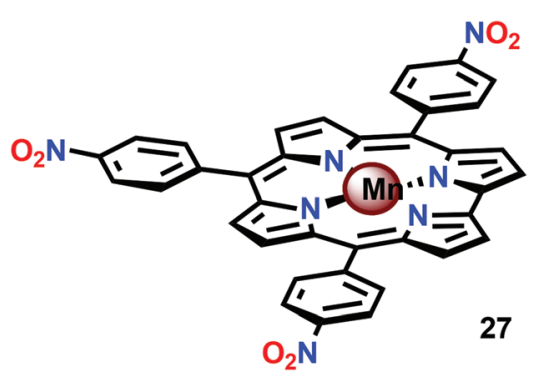

Fig. 16 Structure of mononuclear Mn corrole complex 27. 


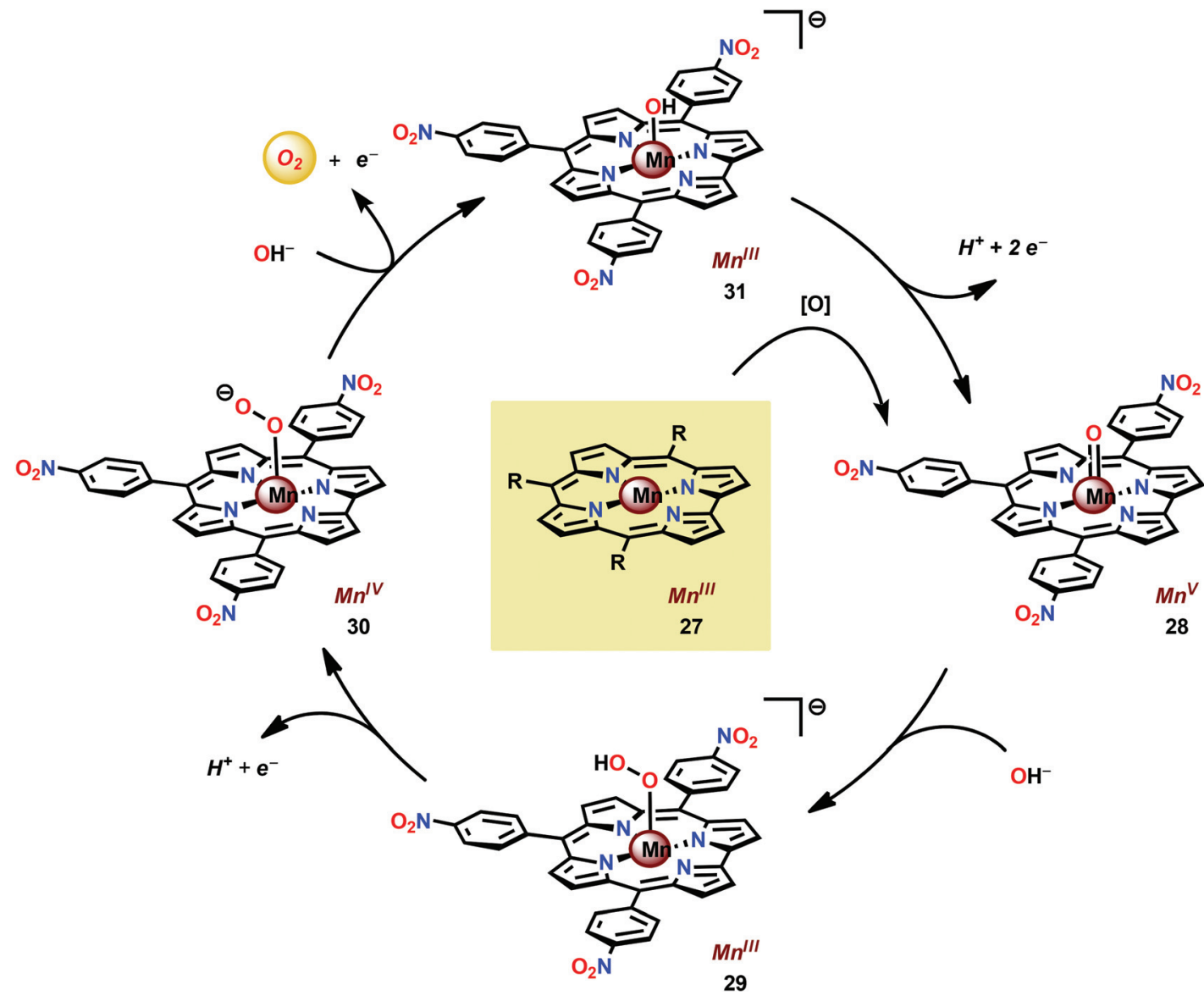

Scheme 3 Proposed mechanism for $\mathrm{O}_{2}$ evolution catalyzed by mononuclear Mn corrole complex 27 .

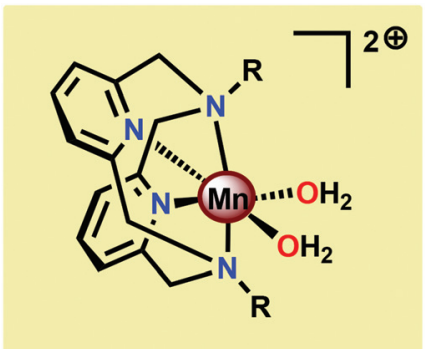

32: $\mathrm{R}=\mathrm{H}$

33: $\mathrm{R}=\mathrm{Me}$

34: $R=t B u$

Fig. 17 Structure of $\mathrm{Mn}^{\text {"l }}$ pyridinophane complexes 32-34.

linearly with the concentration of Mn complex 34, indicating that $\mathrm{O}-\mathrm{O}$ bond formation occurs at a single metal center. ${ }^{121}$ The results highlight that a ligand-controlled switch in catalytic reactivity has implications for the design of novel Mnbased WOCs.

Brudvig and co-workers recently investigated the $\mathrm{H}_{2} \mathrm{O}$ oxidation ability of the three mononuclear $\mathrm{Mn}$ complexes depicted in Fig. 18; $\left[\mathrm{Mn}\left(\mathrm{PaPy}_{3}\right)\left(\mathrm{NO}_{3}\right)\right]^{+}\left(35 ; \mathrm{HPaPy}_{3}{ }^{123}=N, N-\right.$ bis(2-pyridylmethyl)-amine- $N$-ethyl-2-pyridine-2-carboxamide), $[\mathrm{Mn}(\mathrm{N} 4 \mathrm{Py})(\mathrm{OTf})]^{+}\left(36 ; \mathrm{N} \mathrm{Py}^{124,125}=N, N\right.$-bis(2-pyridyl-methyl)$N$-bis(2-pyridyl)methylamine) and $\left.\operatorname{Mn}(\mathrm{PY} 5)\left(\mathrm{OH}_{2}\right)\right]^{2+}(37$;
$\mathrm{PY}^{126,127}=2,6$-bis(methoxydi(pyridin-2-yl)methyl)pyridine). ${ }^{128}$ To facilitate access to the key high-valent Mn-oxo species required to initiate $\mathrm{O}-\mathrm{O}$ bond formation, an electron-rich ligand scaffold is essential. The PaPy3 ${ }^{-}$ligand was chosen as it has been shown that deprotonated carboxamido units are strong electron donors and have previously been employed for isolation of high-valent $\mathrm{Mn}^{\mathrm{V}}=\mathrm{O}$ compounds. ${ }^{129-131}$ It was envisioned that the inclusion of the carboxamido unit at the trans position to the oxo site could favor a reactive species by weakening the Mn-oxo bond. Catalytic experiments revealed that Mn complex $\left[\mathrm{Mn}\left(\mathrm{PaPy}_{3}\right)\left(\mathrm{NO}_{3}\right)\right]^{+}(35)$ was able to catalyze $\mathrm{O}_{2}$ formation using either Oxone ${ }^{\circledR}$ or $\mathrm{H}_{2} \mathrm{O}_{2}$ as a two-electron oxidant and kinetic studies showed that the reaction was first-order in the catalyst. However, Mn complex $[\mathrm{Mn}(\mathrm{N} 4 \mathrm{Py})(\mathrm{OTf})]^{+}$(36) was shown to evolve $\mathrm{O}_{2}$ only in the presence of Oxone ${ }^{\circledR}$ while $\mathrm{Mn}$ complex $\left.\mathrm{Mn}(\mathrm{PY} 5)\left(\mathrm{OH}_{2}\right)\right]^{2+}(37)$ was found to be inactive. ${ }^{128}$

The use of the anionic carboxamido ligand in Mn complex 35 is most apparent in the comparison of the $\mathrm{O}_{2}$ evolution rate, where complex 35 had a significantly higher rate than that of Mn complex 36. The different features of the anionic $\mathrm{PaPy}_{3}{ }^{-}$ligand compared to the neutral ligand backbones are further highlighted by the fact that complexation with Mn produces the $\mathrm{Mn}^{\mathrm{III}}$ complex 35 in air. However, the corresponding $\mathrm{Mn}^{\mathrm{III}}$ complex $\left.\mathrm{Mn}(\mathrm{PY} 5)\left(\mathrm{OH}_{2}\right)\right]^{3+}\left(37^{+}\right)$requires oxidation with 


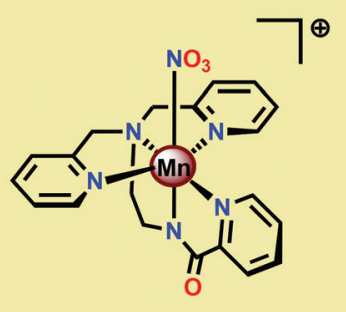

35

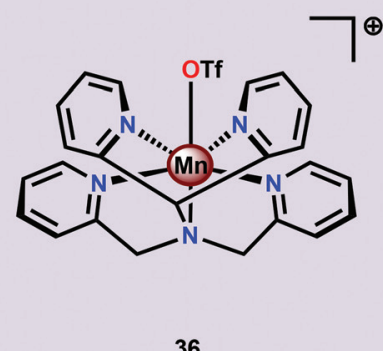

36

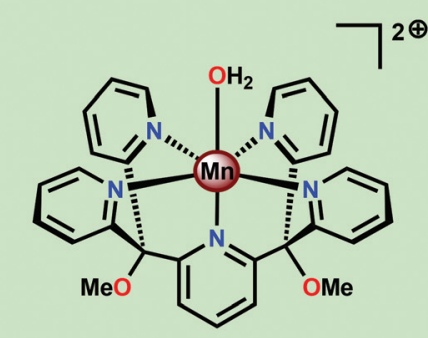

37

Fig. 18 Structures of mononuclear Mn complexes $\left[\mathrm{Mn}\left(\mathrm{PaPy}_{3}\right)\left(\mathrm{NO}_{3}\right)\right]^{+}(35),[\mathrm{Mn}(\mathrm{N} 4 \mathrm{Py})(\mathrm{OTf})]^{+}(36)$ and $\left.\mathrm{Mn}(\mathrm{PY} 5)\left(\mathrm{OH}_{2}\right)\right]^{2+}(37)$.

e.g. PhIO. ${ }^{128}$ The $\mathrm{Mn}^{\mathrm{III}}$ complex $37^{+}$is stable in air but decomposes rapidly in aqueous solutions to heterogeneous $\mathrm{Mn}$ oxides. ${ }^{132}$ The stability difference between the two $\mathrm{Mn}^{\mathrm{III}}$ complexes 35 and $37^{+}$demonstrates the power of using anionic ligand backbones for stabilizing high-valent Mn species, a critical feature for the activation of $\mathrm{H}_{2} \mathrm{O}$.

\subsection{Mn cubanes-bioinspired mimics of the $\mathrm{Mn}_{4} \mathrm{Ca}$ core in Photosystem II}

Molecular mimics of the $\mathrm{Mn}_{4} \mathrm{Ca}$ cluster core in the OEC have attracted significant attention from researchers. Such artificial Mn clusters are highly desired and could facilitate the understanding of the chemical features of the OEC, and could ultimately be used for designing artificial molecular Mn-based WOCs. ${ }^{133}$ Numerous multinuclear Mn clusters have been developed as artificial OEC mimics, ${ }^{134-140}$ for example, the $\left[\mathrm{Mn}_{13} \mathrm{Ca}_{2} \mathrm{O}_{10}(\mathrm{OH})_{2}(\mathrm{OMe})_{2}\left(\mathrm{O}_{2} \mathrm{CPh}\right)_{18}\left(\mathrm{OH}_{2}\right)_{4}\right]$ cluster (38, Fig. 19, top), which contains $\left[\mathrm{Mn}_{4} \mathrm{CaO}_{4}\right]$ sub-units (Fig. 19, bottom), ${ }^{141}$ and the $\left[\mathrm{Mn}_{3}^{\mathrm{IV}} \mathrm{Ca}_{2} \mathrm{O}_{4}\left(\mathrm{O}_{2} \mathrm{C}^{t} \mathrm{Bu}\right)_{8}\left({ }^{t} \mathrm{BuCO}_{2} \mathrm{H}\right)_{4}\right]$ cubane. ${ }^{142}$

The heterometallic [ $\mathrm{Mn}_{3}^{\mathrm{III}} \mathrm{CaNa}$ ] cluster 39 based on a Schiff base ligand (Fig. 20) was recently reported by Reedijk and coworkers. ${ }^{143}$ This $\mathrm{Mn}_{3} \mathrm{Ca}$ cluster was found to evolve $\mathrm{O}_{2}$ using $\mathrm{NaOCl}$, Oxone ${ }^{\circledR}$ or $t \mathrm{BuOOH}$ as a chemical oxidant. However, the molecular nature of the developed cluster was not thoroughly investigated in order to rule out the formation of heterogeneous metal oxides as the active catalytic entity.

Perhaps the most well-studied tetranuclear Mn mimic is the $\left[\mathrm{Mn}_{4} \mathrm{O}_{4}(\mathrm{dpp})_{6}\right]$ cubane 40 (dpp = diphenylphosphinate), which contains a cubical $\left[\mathrm{Mn}_{4} \mathrm{O}_{4}\right]^{6+}$ core surrounded by six facially bridging bidentate diphenylphosphinate groups coordinated to the Mn centers (Fig. 21). ${ }^{144-146} \mathrm{Mn}$ cubanes, such as the $\left[\mathrm{Mn}_{4} \mathrm{O}_{4}(\mathrm{dpp})_{6}\right]$ cubane 40, self-assemble from mononuclear precursors $^{145}$ or from dimeric complexes housing a $\left[\mathrm{Mn}_{2} \mathrm{O}_{2}\right]^{3+}$ core in the presence of phosphinate ligands. ${ }^{144}$ The three oxo units and the three anionic phosphinate ligands provide an electron-rich environment for the $\mathrm{Mn}$ centers. The electrochemical properties of the $\left[\mathrm{Mn}_{4} \mathrm{O}_{4}(\mathrm{dpp})_{6}\right]$ cubane $\mathbf{4 0}$ have also been investigated. ${ }^{147}$ Electrochemical oxidation of the $\left[\mathrm{Mn}_{4} \mathrm{O}_{4}\right]^{6+}$ core in cubane 40 occurs at a potential of $\sim 0.94 \mathrm{~V}$ $v s$. NHE and generates the one-electron oxidized $\mathrm{Mn}^{\mathrm{III}} \mathrm{Mn}_{3}^{\mathrm{IV}}$ core. The redox potentials are ligand-dependent, indicating
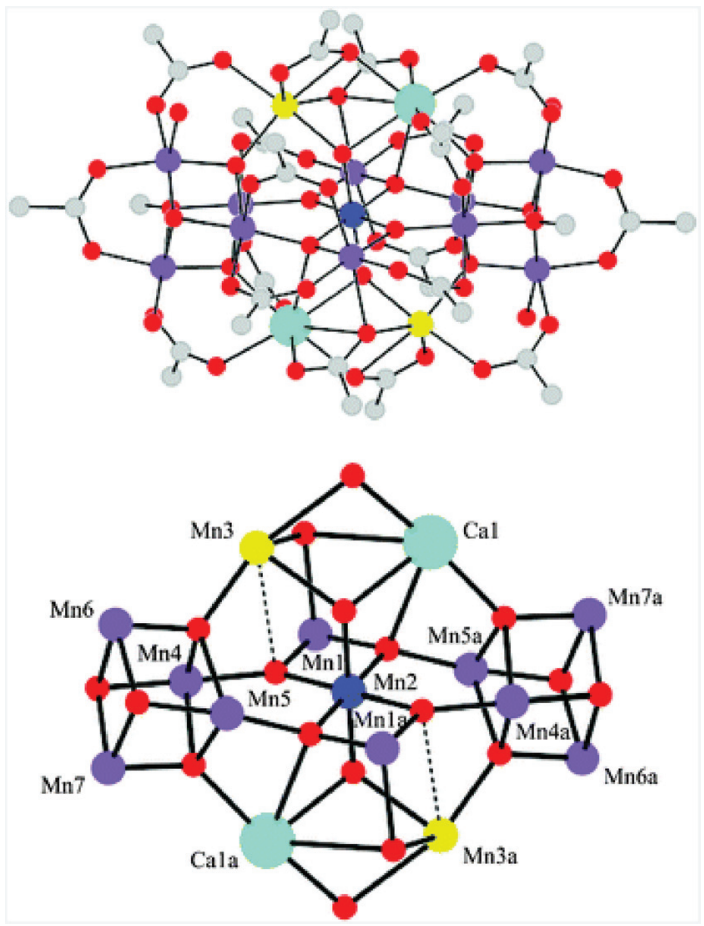

Fig. 19 Structure of the $\left[\mathrm{Mn}_{13} \mathrm{Ca}_{2} \mathrm{O}_{10}(\mathrm{OH})_{2}(\mathrm{OMe})_{2}\left(\mathrm{O}_{2} \mathrm{CPh}\right)_{18}\left(\mathrm{OH}_{2}\right)_{4}\right]$ cluster (38) containing $\left[\mathrm{Mn}_{4} \mathrm{CaO}_{4}\right]$ sub-units. Color code: cyan (Ca), blue $\left(\mathrm{Mn}^{\mathrm{IV}}\right)$, violet $\left(\mathrm{Mn}^{\mathrm{III}}\right)$, yellow $\left(\mathrm{Mn}^{\mathrm{II}}\right)$, red $(\mathrm{O})$, and grey $(\mathrm{C})$. Reprinted from ref. 141 with permission from the Royal Society of Chemistry.

that they can be tuned using supporting phosphinate ligands with stronger electron donation. ${ }^{148,149}$

The $\left[\mathrm{Mn}_{4} \mathrm{O}_{4}(\mathrm{dpp})_{6}\right]$ cubane $\mathbf{4 0}$ has also been reported to liberate stoichiometric amounts of $\mathrm{O}_{2}$ upon UV-light irradiation. The necessity for one of the phosphinate ligands to dissociate before $\mathrm{O}_{2}$ evolution can occur was demonstrated by isotopic labeling experiments in combination with mass spectrometry, with $\mathrm{O}-\mathrm{O}$ bond formation occurring via direct coupling of two bridging oxo groups. ${ }^{150-153}$ Furthermore, Mn cubane 40 has been suspended in Nafion, a proton-conducting polymer matrix, for sustained $\mathrm{O}_{2}$ evolution. The generated Nafion ${ }^{154}$ polymer films were deposited on a variety of electrodes and reached TONs of $>1000$ and rates of $0.075 \mathrm{O}_{2}$ molecules 


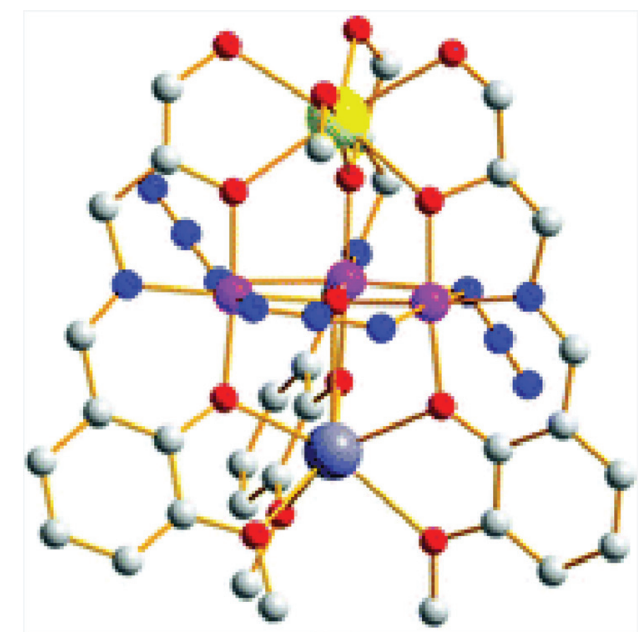

Fig. 20 Structure of the heterometallic [Mn $\mathrm{Mn}_{3}^{\mathrm{III}} \mathrm{CaNa}$ ] cluster 39. Hydrogen atoms are omitted for clarity. Color code: blue (N), large, dark-gray $(\mathrm{Na})$, gray $(\mathrm{C})$, red $(\mathrm{O})$, violet $(\mathrm{Mn})$, and yellow $(\mathrm{Ca})$. Adapted from ref. 143 with permission from the Royal Society of Chemistry.

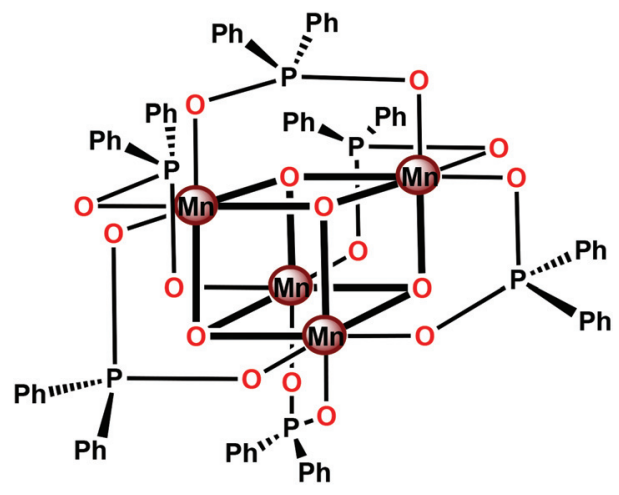

40

Fig. 21 Structure of the $\left[\mathrm{Mn}_{4} \mathrm{O}_{4}(\mathrm{dpp})_{6}\right]$ cubane $40 . \mathrm{dpp}=$ diphenylphosphinate.

per s per $\mathrm{Mn}_{4}$ cluster at an overpotential of $0.38 \mathrm{~V}$ at $\mathrm{pH} 6$ when illuminated with light of wavelength $275-750 \mathrm{~nm} .^{155-159}$ A photoelectrochemical cell has also been designed where the Nafion film embedded with cubane $\mathbf{4 0}$ was coupled to a $\left[\mathrm{Ru}(\text { bpy })_{3}\right]^{2+}$-type sensitized $\mathrm{TiO}_{2}$ layer (Fig. 22). The produced photoelectrochemical cell was able to catalyze the photooxidation of $\mathrm{H}_{2} \mathrm{O}$ using visible-light as the sole energy source, reaching TONs of $13 \mathrm{O}_{2}$ molecules per Mn cluster and TOFs of $\sim 0.013 \mathrm{O}_{2}$ molecules per s per Mn cluster. ${ }^{160}$ However, a recent report suggests that bulk electrolysis of the Nafion embedded cubane causes it to dissociate into $\mathrm{Mn}^{\mathrm{II}}$ compounds. These compounds are subsequently reoxidized to produce nanoparticles composed of $\mathrm{Mn}^{\mathrm{III} / \mathrm{IV}}$ oxides; thus the original Mn cubane cluster merely serves as a precursor to the catalytically active nanoparticle material. ${ }^{161}$

$\mathrm{Ca}^{2+}$ is essential in the natural OEC for triggering $\mathrm{O}-\mathrm{O}$ bond formation and $\mathrm{O}_{2}$ release and tuning the electrochemical

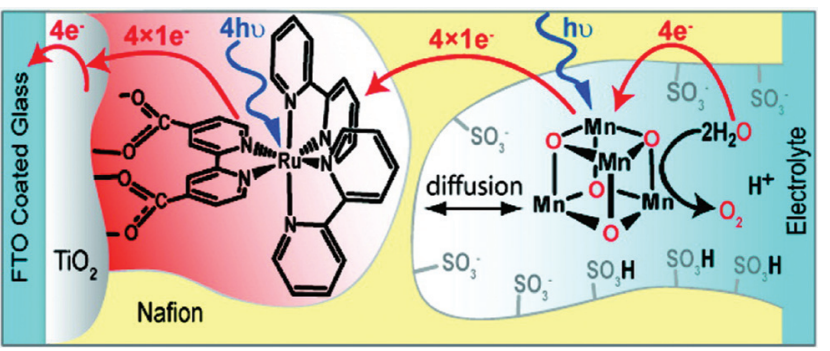

Fig. 22 Schematic depiction of the photoelectrochemical cell containing Mn cubane 40. Reprinted with permission from ref. 160. Copyright 2010 American Chemical Society.

properties of the $\mathrm{Mn}_{4} \mathrm{Ca}$ cluster. ${ }^{162-164}$ Agapie and co-workers therefore recently synthesized a $\left[\mathrm{Mn}_{3} \mathrm{CaO}_{4}\right]^{6+}$ cubane (41) that models the $\mathrm{Mn}_{4} \mathrm{Ca}$ core of the OEC. Structural and electrochemical comparison between the $\left[\mathrm{Mn}_{3} \mathrm{CaO}_{4}\right]^{6+}$ cubane 41 (Fig. 23, left) and a related $\mathrm{Mn}_{4} \mathrm{O}_{4}$ cubane (42, Fig. 23, right) demonstrated that the redox-inactive metal facilitates access to higher redox states and the assembly of the cluster. ${ }^{165}$ Subsequent work focused on the synthesis of a series of $\left[\mathrm{Mn}_{3} \mathrm{M}\left(\mu_{4}-\mathrm{O}\right)\left(\mu_{2}-\mathrm{O}\right)\right]$ clusters $^{166}\left(\right.$ where $\mathrm{M}=\mathrm{Na}^{+}, \mathrm{Ca}^{2+}, \mathrm{Sr}^{2+}, \mathrm{Zn}^{2+}$ or $\mathrm{Y}^{3+}$ ) and $\left[\mathrm{Mn}_{3} \mathrm{M}^{\prime} \mathrm{O}_{4}\right]$ clusters ${ }^{167}$ (where $\mathrm{M}^{\prime}=\mathrm{Sr}^{2+}, \mathrm{Zn}^{2+}, \mathrm{Sc}^{3+}$, $\mathrm{Y}^{3+}$; see Fig. 24 for the structure of the $\mathrm{Mn}_{3} \mathrm{ScO}_{4}$ cubane 43). Here, the redox-inactive metal was shown to modulate the redox potentials of the heterobimetallic Mn clusters. These studies have provided a methodology with unprecedented structural control for the rational synthesis of Mn-based mimics of the $\mathrm{Mn}_{4} \mathrm{Ca}$ core of the OEC. ${ }^{168-171}$ The $\left[\mathrm{Mn}_{3} \mathrm{M}^{\prime} \mathrm{O}_{4}\right]$ cubanes have recently been dropcast on ITO or glassy carbon disk electrodes and used as precursors to heterogeneous electrocatalysts for $\mathrm{H}_{2} \mathrm{O}$ oxidation. ${ }^{172}$ Multinuclear clusters of the type $\left[\mathrm{Mn}_{12} \mathrm{O}_{12}\right]$ have also been demonstrated to be viable $\mathrm{H}_{2} \mathrm{O}$ oxidation electrocatalysts. ${ }^{173}$

Mechanistic understanding of the biological $\mathrm{Mn}_{4} \mathrm{Ca}$ cluster in the OEC at a molecular level is highly desirable for the rational design of viable WOCs. The collective work on the Mn-based model clusters has provided valuable insight into
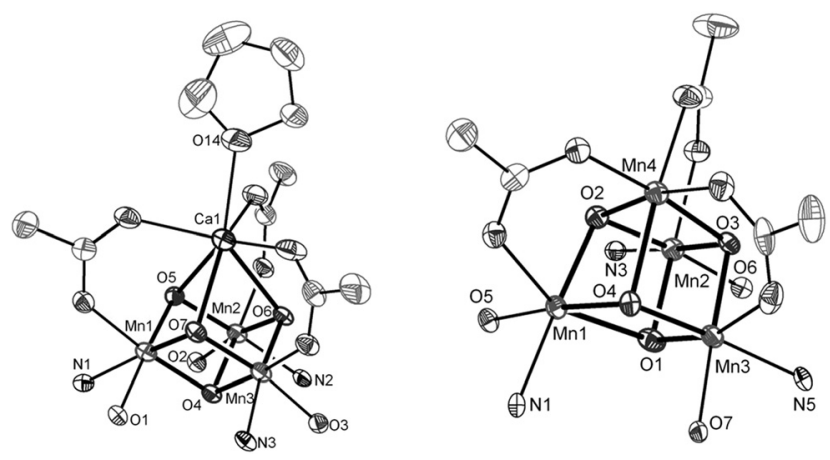

Fig. 23 Structures of (left) the $\left[\mathrm{Mn}_{3} \mathrm{CaO}_{4}\right]^{6+}$ cubane core in 41 and (right) the $\mathrm{Mn}_{4} \mathrm{O}_{4}$ cubane core (42). Adapted with permission from ref. 165. Copyright 2011 American Association for the Advancement of Science (AAAS). 


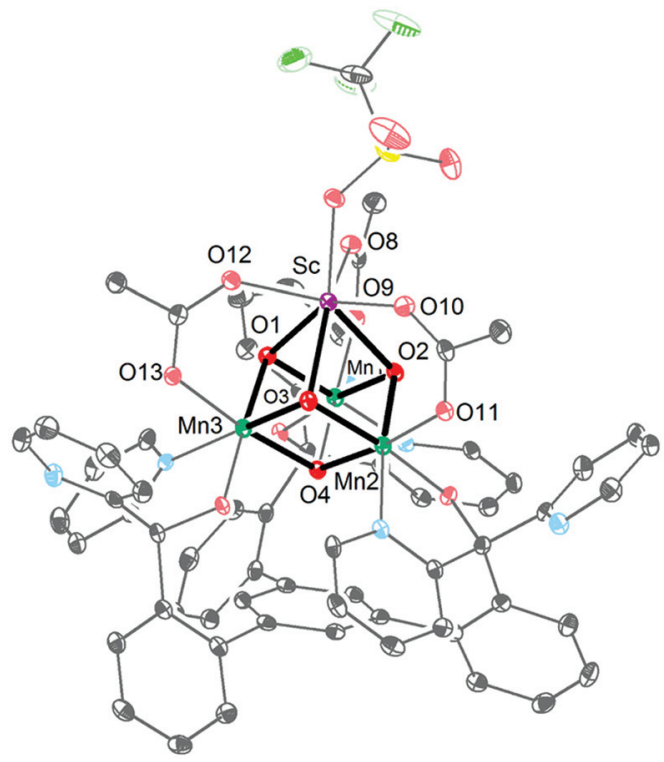

Fig. 24 Structure of the $\mathrm{Mn}_{3} \mathrm{ScO}_{4}$ cubane 43. Reprinted with permission from ref. 169. Copyright 2013 American Chemical Society.

the properties and function of the natural OEC. Given the interesting properties associated with the Mn cluster mimics, it is expected that this research area will continue to expand and thus offers a promising future for producing artificial model systems for activation of small molecules, such as $\mathrm{H}_{2} \mathrm{O}$.

\section{Homogeneous Fe-based complexes for water oxidation}

Fe is an essential element in a variety of enzymes and perhaps the most important transition metal from a biological point of view. Fe catalysis has emerged as a prominent research field and in recent years there has been a tremendous development in this area. ${ }^{174} \mathrm{Fe}$ is known to have a rich redox chemistry and to adopt a variety of redox states. In addition to having access to this broad spectrum of redox states, Fe-complexes have the ability to engage in both one- and two-electron processesessential features for $\mathrm{H}_{2} \mathrm{O}$ oxidation catalysis. The large number of spin states accessible to Fe should also make it amenable to tuning, by varying the ligand environment. Although $\mathrm{Fe}$ is associated with these attractive properties, relatively few examples exist of Fe-catalyzed $\mathrm{H}_{2} \mathrm{O}$ oxidation.

\subsection{Mononuclear Fe-based catalysts}

Seminal work on Fe-catalyzed $\mathrm{H}_{2} \mathrm{O}$ oxidation has already been carried out in the 1980s. ${ }^{175}$ However, the first examples of homogeneous Fe-based WOCs were reported by Collins and co-workers in $2010 .{ }^{176}$ In order to stabilize the Fe center, the authors employed tetraamido macrocyclic ligands (TAMLs). These ligands have previously been shown to efficiently activate $\mathrm{O}_{2}$ and peroxides to produce $\mathrm{Fe}_{2}^{\mathrm{IV}}-\mu$-oxo species. ${ }^{177-179}$ In aqueous solutions, the $\mathrm{Fe}_{2}^{\mathrm{IV}}-\mu$-oxo species have been shown to participate in a $\mathrm{pH}$-dependent equilibrium with a monomeric $\mathrm{Fe}^{\mathrm{IV}}$-oxo complex. ${ }^{180}$ Furthermore, the initial Fe $\mathrm{FII}^{\mathrm{III}}$-TAML complexes react with peracids to produce the corresponding $\mathrm{Fe}^{\mathrm{V}}$-oxo complexes. ${ }^{181}$ The diverse and high reactivity associated with the Fe-TAML complexes thus rendered these catalysts attractive targets for use in $\mathrm{H}_{2} \mathrm{O}$ oxidation.

Fe-TAML complexes 44-48 (Fig. 25) were therefore investigated toward $\mathrm{H}_{2} \mathrm{O}$ oxidation. In the presence of $\mathrm{Ce}^{\mathrm{IV}}$ as a chemical oxidant, fast $\mathrm{O}_{2}$ evolution was observed for complexes 45-48. However, no $\mathrm{O}_{2}$ production was detected for the least acid stable Fe-TAML complex 44. The rate of $\mathrm{O}_{2}$ evolution was shown to be highly dependent on the electron-withdrawing ability of the macrocyclic ligand. Fe-TAML complex 48 gave the highest TOF, $1.3 \mathrm{~s}^{-1}$, and was shown to display a firstorder dependence on the catalyst concentration, implying that $\mathrm{O}-\mathrm{O}$ bond formation occurs at a single metal center. $\mathrm{H}_{2} \mathrm{O}$ oxidation could also be driven using $\mathrm{NaIO}_{4}$ as a chemical oxidant. Mechanistic studies using $\mathrm{NaIO}_{4}$ as an oxidant also concluded that an $\mathrm{Fe}^{\mathrm{IV}}-\mu$-oxo- $\mathrm{Fe}^{\mathrm{IV}}$ species is involved in the oxidation process. ${ }^{176}$ Although this seminal work highlighted that Febased WOCs could be designed, the catalysts were prone to undergo fast deactivation/decomposition, highlighting that more robust WOCs need to be targeted. In an attempt to improve the longevity of the Fe-TAML complexes, they were subsequently immobilized on electrodes for electrocatalytic $\mathrm{H}_{2} \mathrm{O}$ oxidation. ${ }^{182}$

Dhar and co-workers subsequently employed the modified Fe-TAML complex 49 (Fig. 26) to carry out light-driven $\mathrm{H}_{2} \mathrm{O}$ oxidation using $\left[\mathrm{Ru}(\mathrm{bpy})_{3}\right]^{2+}$ as a photosensitizer and $\mathrm{Na}_{2} \mathrm{~S}_{2} \mathrm{O}_{8}$ as a sacrificial electron acceptor. ${ }^{183}$ The photocatalytic system was shown to produce a TON of 220 and a TOF of $0.67 \mathrm{~s}^{-1}$. An $\mathrm{Fe}^{\mathrm{V}}$-oxo intermediate was proposed to be generated in this system as supported by EPR, UV-vis and HRMS studies. Based on these results and related studies, ${ }^{184-188}$ the authors proposed a mechanism, outlined in Scheme 4, where the generated $\mathrm{Fe}^{\mathrm{V}}$-oxo species $\mathbf{5 2}$ undergoes nucleophilic attack by a $\mathrm{H}_{2} \mathrm{O}$ molecule to form a $\mathrm{Fe}^{\mathrm{III}}$-hydroperoxo $\left(\mathrm{Fe}^{\mathrm{III}}-\mathrm{OOH}\right)$ species (53). Subsequent oxidation of this $\mathrm{Fe}^{\mathrm{III}}-\mathrm{OOH}$ species leads to

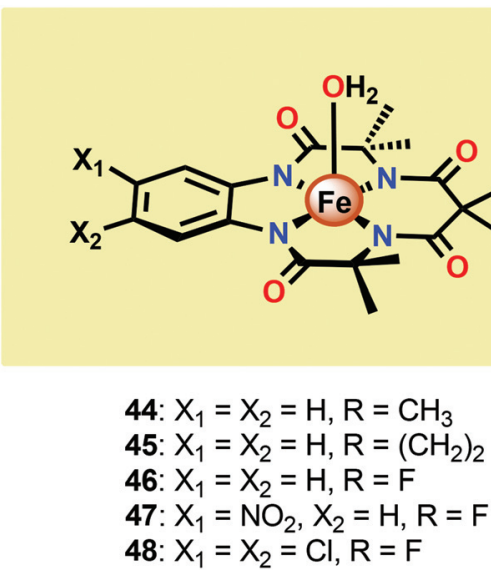

Fig. 25 Structure of Fe"I-TAML complexes 44-48. 


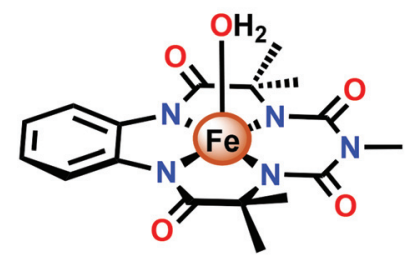

49

Fig. 26 Structure of modified Fe-TAML complex 49

$\mathrm{O}_{2}$ liberation and regenerates the starting aqua complex 49, $\mathrm{Fe}^{\mathrm{III}}-\mathrm{OH}_{2} \cdot{ }^{183}$

An alternative mechanism for the oxidation of $\mathrm{H}_{2} \mathrm{O}$ by the Fe-TAML complexes was presented by Liao and Siegbahn. ${ }^{189}$ This mechanism was proposed to involve the formation of a formal $\mathrm{Fe}^{\mathrm{VI}}$-oxo species, which upon further inspection was better described as having an $\mathrm{Fe}^{\mathrm{V}}$ center with a ligand cation radical. Three distinct ligand modification pathways were also realized: (1) $\mathrm{H}_{2} \mathrm{O}$ or (2) nitrate (the anion originating from the $\mathrm{Ce}^{\mathrm{IV}}$ oxidant) attack on the ligand framework, and (3) amide oxidation. The pathway involving $\mathrm{H}_{2} \mathrm{O}$ attack on the ligand was associated with a low barrier and results in the opening of the benzene ring. The observed reactivity pattern for the Fe-TAML complexes 44-48 could also be rationalized as it was found that the barrier for $\mathrm{O}-\mathrm{O}$ bond formation decreased with electron-withdrawing substituents. However, the introduction of electron-withdrawing units increases the redox potentials and adds an additional energetic penalty. These effects need to be carefully balanced in future designs of ligands.

Another class of Fe-based WOCs was described by LloretFillol and co-workers. ${ }^{190}$ The authors evaluated the catalytic activity of a series of Fe complexes based on tetra- and pentadentate ligand motifs (Fig. 27). From the study, it could be shown that Fe complexes 54-58 having two open coordination sites in a cis configuration were competent WOCs. The structural requirement was further confirmed by complexes $\mathbf{5 9}$ and 60, with a trans configuration or possessing only a single coordination site, which were found to be inactive. Of the evaluated catalysts, Fe complex $\mathbf{5 5}_{\boldsymbol{\alpha}}$ afforded a TON of $>1000$ and a TOF of $0.062 \mathrm{~s}^{-1}$ using $\mathrm{NaIO}_{4}$ as a chemical oxidant. Mechanistic investigations employing the dimeric $\mathrm{Fe}_{2}^{\mathrm{III}, \mathrm{III}}(\mu-\mathrm{OH})(\mu-\mathrm{O})$ complex of catalyst $\mathbf{5 5}_{\boldsymbol{\alpha}}$ showed that the dimeric complex was associated with a lower reaction rate and a different kinetic behavior, discarding such dimeric structures as essential active intermediates in the studied Fe-based system. Addition of 6 equivalents of $\mathrm{Ce}^{\mathrm{IV}}$ oxidant resulted in the appearance of new

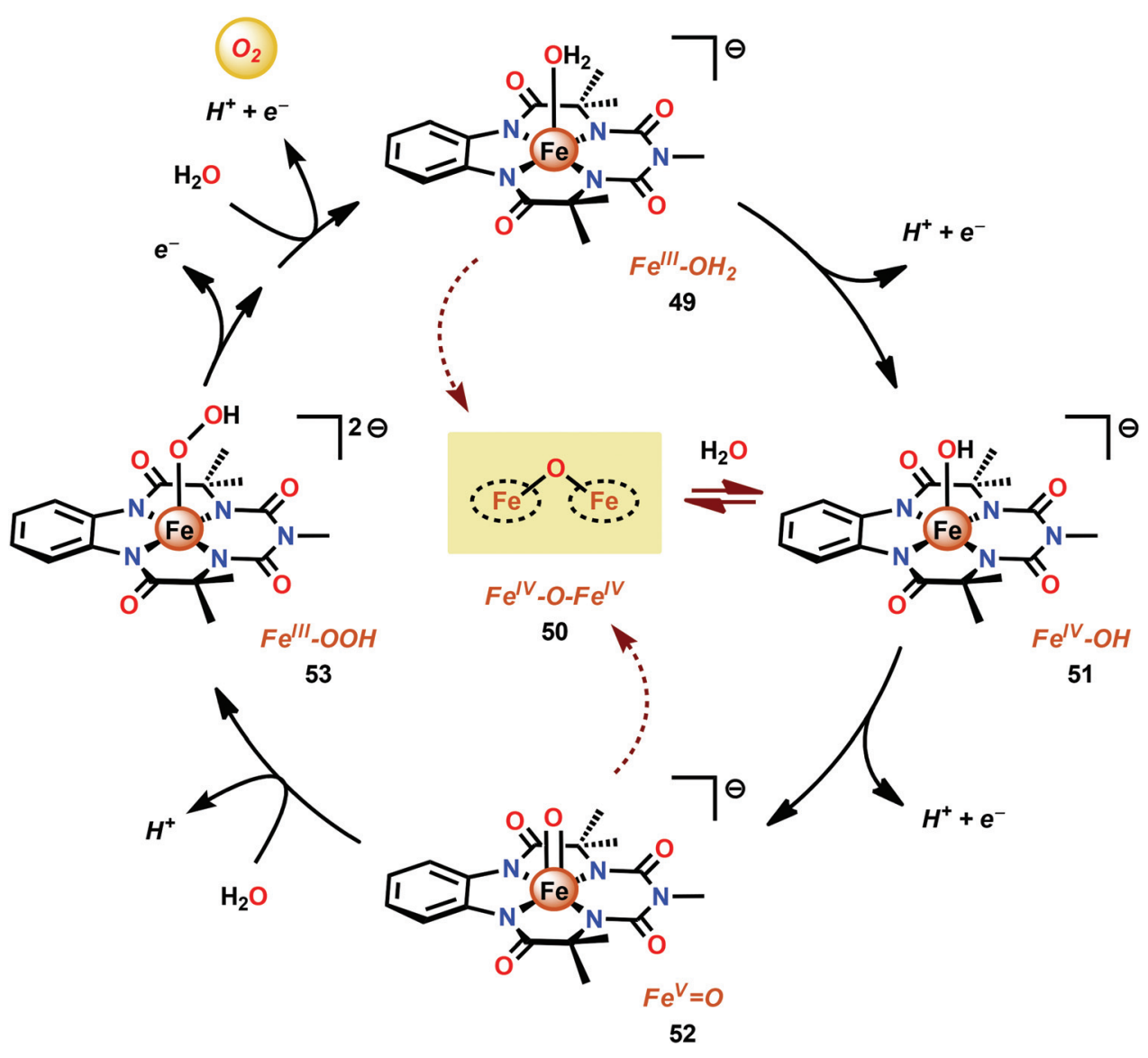

Scheme 4 Proposed mechanism for $\mathrm{H}_{2} \mathrm{O}$ oxidation catalyzed by modified Fe-TAML complex 49 . 
active catalysts

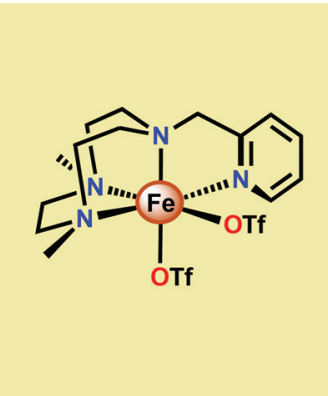

54

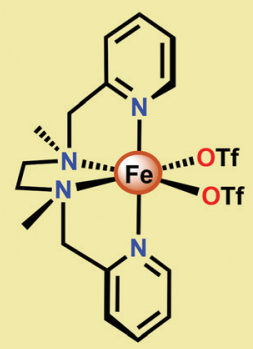

57

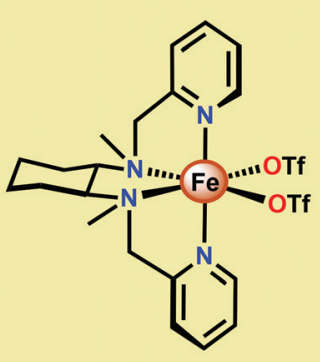

$55_{\alpha}$

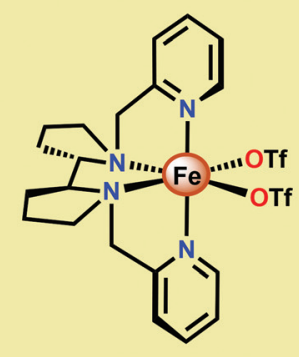

56

\section{inactive catalysts}

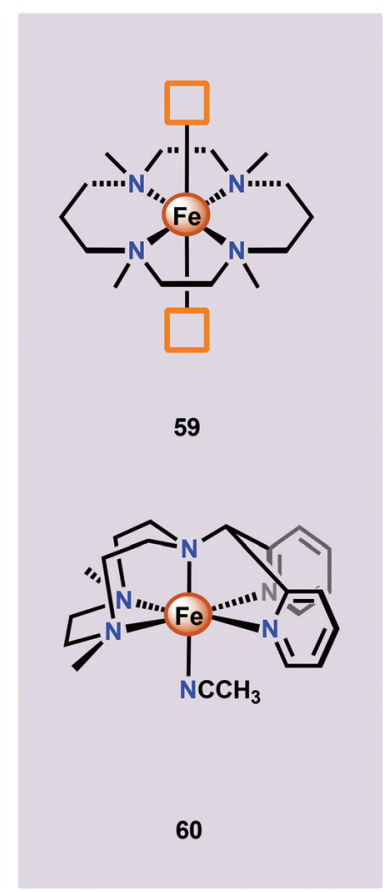

Fig. 27 Structures of Fe complexes 54-60 containing tetra- and pentadentate nitrogen-based ligands.

bands in the UV-vis, a species characteristic of an $\mathrm{Fe}^{\mathrm{IV}}$-oxo intermediate. The persistence of this $\mathrm{Fe}^{\mathrm{IV}}$-oxo indicated that this species is not responsible for mediating $\mathrm{O}-\mathrm{O}$ bond formation, and that species of higher valency are needed for $\mathrm{O}-\mathrm{O}$ bond forming events.

Several mechanistic studies on Fe complexes of the type 54-58 have also been carried out. ${ }^{191-195}$ A follow-up study by Lloret-Fillol and co-workers involved the electronic tuning of the Fe-based catalyst $\mathbf{5 4}$ in which a family of substituted Fe complexes (61-65, Fig. 28) were synthesized. Using Hammett parameters, the rate of $\mathrm{O}_{2}$ evolution was found to correlate with the electronic nature of the introduced substituents, with electron-withdrawing substituents favoring $\mathrm{O}_{2}$ production. The non-innocent effect of the $\mathrm{Ce}^{\mathrm{IV}}$ cation was also observed in which a $\mathrm{Fe}^{\mathrm{IV}}(\mathrm{OH})\left(\mathrm{O}-\mathrm{Ce}^{\mathrm{IV}}\right)$ adduct was proposed to be involved prior to the O-O bond forming step. ${ }^{191}$

A recent study identified $\mathrm{Fe}^{\mathrm{IV}}(\mathrm{O})\left(\mathrm{O}-\mathrm{Ce}^{\mathrm{IV}}\right)$ as the key reaction intermediate in $\mathrm{H}_{2} \mathrm{O}$ oxidation using Fe complex 55. ${ }^{193}$ Here, $\mathrm{Ce}^{\mathrm{IV}}$ was found not to act merely as an inner-sphere oxidant

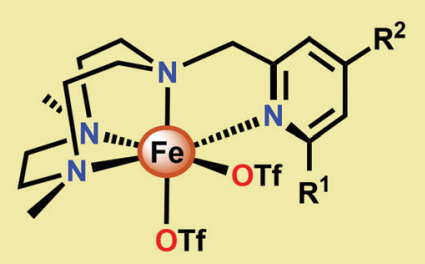

$$
\begin{aligned}
& \text { 54: } R^{1}=R^{2}=H \\
& \text { 61: } R^{1}=H, R^{2}=C l \\
& \text { 62: } R^{1}=H, R^{2}=C_{2} E t \\
& \text { 63: } R^{1}=H, R^{2}=N_{2} \\
& \text { 64: } R^{1}=F, R^{2}=H \\
& \text { 65: } R^{1}=C_{3}, R^{2}=H
\end{aligned}
$$

but was revealed to generate an $\mathrm{Fe}^{\mathrm{IV}}(\mu-\mathrm{O}) \mathrm{Ce}^{\mathrm{IV}}$ species, crucial for the catalytic reaction to proceed. The oxidation of $\mathrm{H}_{2} \mathrm{O}$ with Fe-based complexes such as $\mathbf{5 5}$ not only requires the presence of two open coordination sites in a cis configuration but also a framework that allows the generation of $\mathrm{Fe}^{\mathrm{IV}}(\mu-\mathrm{O}) \mathrm{Ce}^{\mathrm{IV}}$. The isomeric Fe complexes $\mathbf{5 5}_{\boldsymbol{\alpha}}$ and $\mathbf{5 5}_{\boldsymbol{\beta}}$ also displayed different reactivity, arising either from steric encumbrance or electronic effects. While the complex $\mathbf{5 5}_{\boldsymbol{\beta}}$ did not evolve $\mathrm{O}_{2}$, the $\alpha$-isomer was found to produce $\mathrm{O}_{2}$ according to the pathways highlighted in Scheme 5. These findings could thus provide valuable information for future evaluations of earth-abundant WOCs.

The relative ease by which Fe complexes housing tetra- and pentadentate nitrogen-based ligands can be accessed has attracted attention from several research groups. ${ }^{196-198}$ The phosphonate modified Fe complex 71 (Fig. 29) has for example been covalently anchored to $\mathrm{WO}_{3}$ electrodes for photoelectrochemical $\mathrm{H}_{2} \mathrm{O}$ oxidation. The modified electrodes exhibited an increase in photocurrent of $\sim 60 \%$ whereas electrodes modified with $\mathrm{FeCl}_{2}$ or with the pristine tetradentate nitrogen ligand did not display any increase in photocurrent. Although the authors could not preclude that the phosphonate containing $\mathrm{Fe}$ complex 71 tethered to $\mathrm{WO}_{3}$ could potentially be a mere precatalyst for $\mathrm{H}_{2} \mathrm{O}$ oxidation, the observed rate enhancement is noteworthy for the modified $\mathrm{WO}_{3}$ electrodes. ${ }^{199}$

The group of Meyer developed the mononuclear $\left[\mathrm{Fe}(\mathrm{dpaq})\left(\mathrm{OH}_{2}\right)\right]^{2+}$ complex (72, Fig. 30; dpaq $=2$-[bis( pyridine2 -ylmethyl)] amino- $N$-quinolin-8-yl-acetamido), ${ }^{200}$ which has previously been reported to mediate alkane hydroxylation with $\mathrm{H}_{2} \mathrm{O}_{2}$ as an oxidant. ${ }^{201}$ Meyer and co-workers found that the

Fig. 28 Fe complexes 54 and 61-65. 


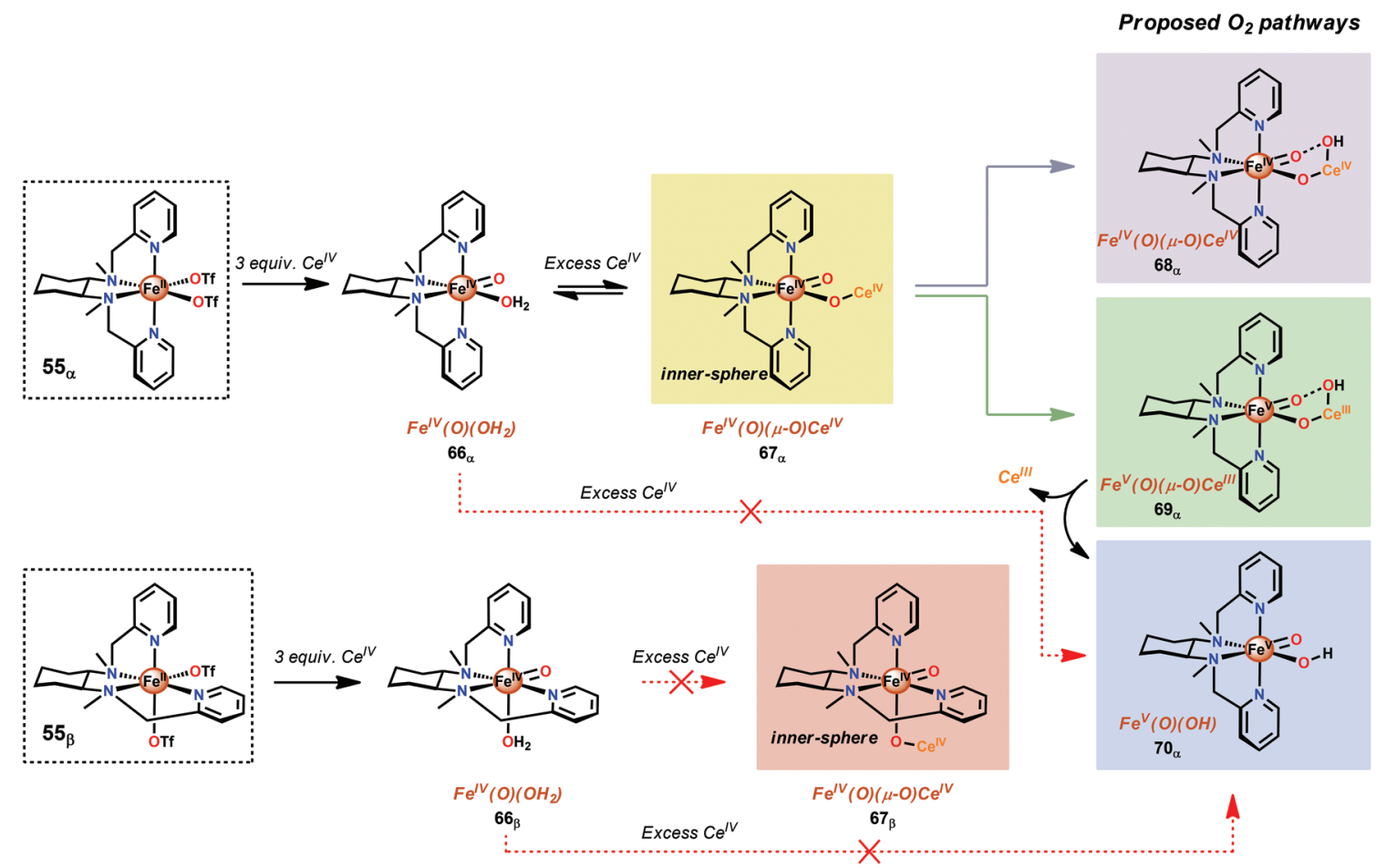

Scheme 5 Reactivity differences between the isomeric Fe complexes $55_{\alpha}$ and $55_{\beta}$.

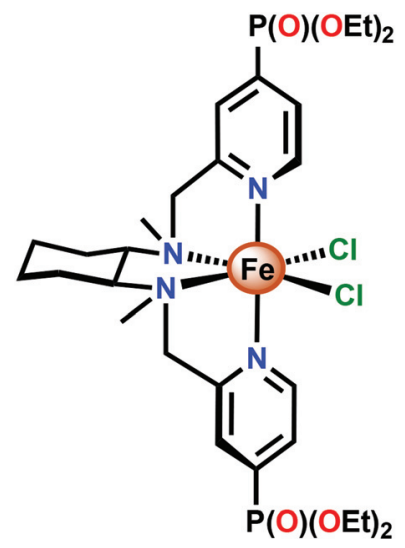

71

Fig. 29 Structure of the phosphonate-functionalized Fe complex 71

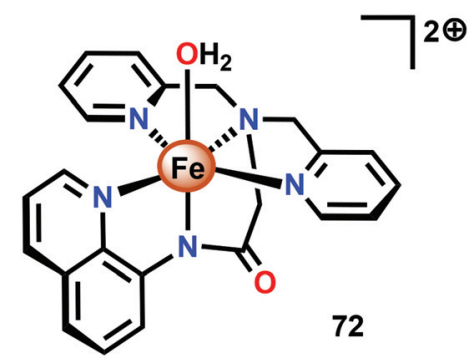

Fig. 30 Structure of the $\left[\mathrm{Fe}(\mathrm{dpaq})\left(\mathrm{OH}_{2}\right)\right]^{2+}$ complex 72 .
$\left[\mathrm{Fe}(\mathrm{dpaq})\left(\mathrm{OH}_{2}\right)\right]^{2+}$ complex 72 was able to catalyze electrochemical $\mathrm{H}_{2} \mathrm{O}$ oxidation in propylene carbonate-water mixtures. Electrochemical examination revealed that the $\mathrm{Fe}$ catalyst exhibited a quasi-reversible one-electron wave at $0.38 \mathrm{~V}$ vs. NHE corresponding to the $\left[\mathrm{Fe}^{\mathrm{III}}-\mathrm{OH}_{2}\right]^{2+} /\left[\mathrm{Fe}^{\mathrm{II}}-\mathrm{OH}_{2}\right]^{+}$redox couple. At higher potentials $(1.58 \mathrm{~V})$, an irreversible twoelectron wave appeared, which was assigned to the oxidation of $\left[\mathrm{Fe}^{\mathrm{III}}\left(\mathrm{OH}_{2}\right)\right]^{2+}$ to $\left[\mathrm{Fe}^{\mathrm{V}}(\mathrm{O})\right]^{2+}$. Following this wave, an increase in current was observed. The peak current was shown to display a first-order dependence on the catalyst concentration, suggesting a rate-limiting reaction between $\left[\mathrm{Fe}^{\mathrm{V}}(\mathrm{O})\right]^{2+}$ and $\mathrm{H}_{2} \mathrm{O}$. This is consistent with a single-site mechanism for $\mathrm{H}_{2} \mathrm{O}$ oxidation as depicted in Scheme $6 .^{200}$

A series of Fe-complexes containing pendant bases have also been synthesized by Yang and co-workers (76-82, Fig. 31). ${ }^{202}$ The authors envisioned that incorporation of bases into the second coordination sphere would facilitate PCET events and lead to enhanced reaction kinetics. However, Fe complexes 78-80 were shown to be inactive catalysts as they were not able to reach the critical $\mathrm{Fe}^{\mathrm{IV}}=\mathrm{O}$ state. For Fe complexes $\mathbf{8 1}$ and $\mathbf{8 2}$, an undesirable change in coordination took place, in contrast to what was observed for the analogous complexes lacking the introduced heteroatoms. Of the developed Fe complexes, only the pyridazine containing complexes 76 and 77 displayed $\mathrm{H}_{2} \mathrm{O}$ oxidation activity similar to the analogous complexes lacking the ancillary proton relays. Although the introduction of proton relays did not improve the catalytic activity of the Fe complexes, the concept of designing ligand motifs containing strategically functionalized moieties able to 


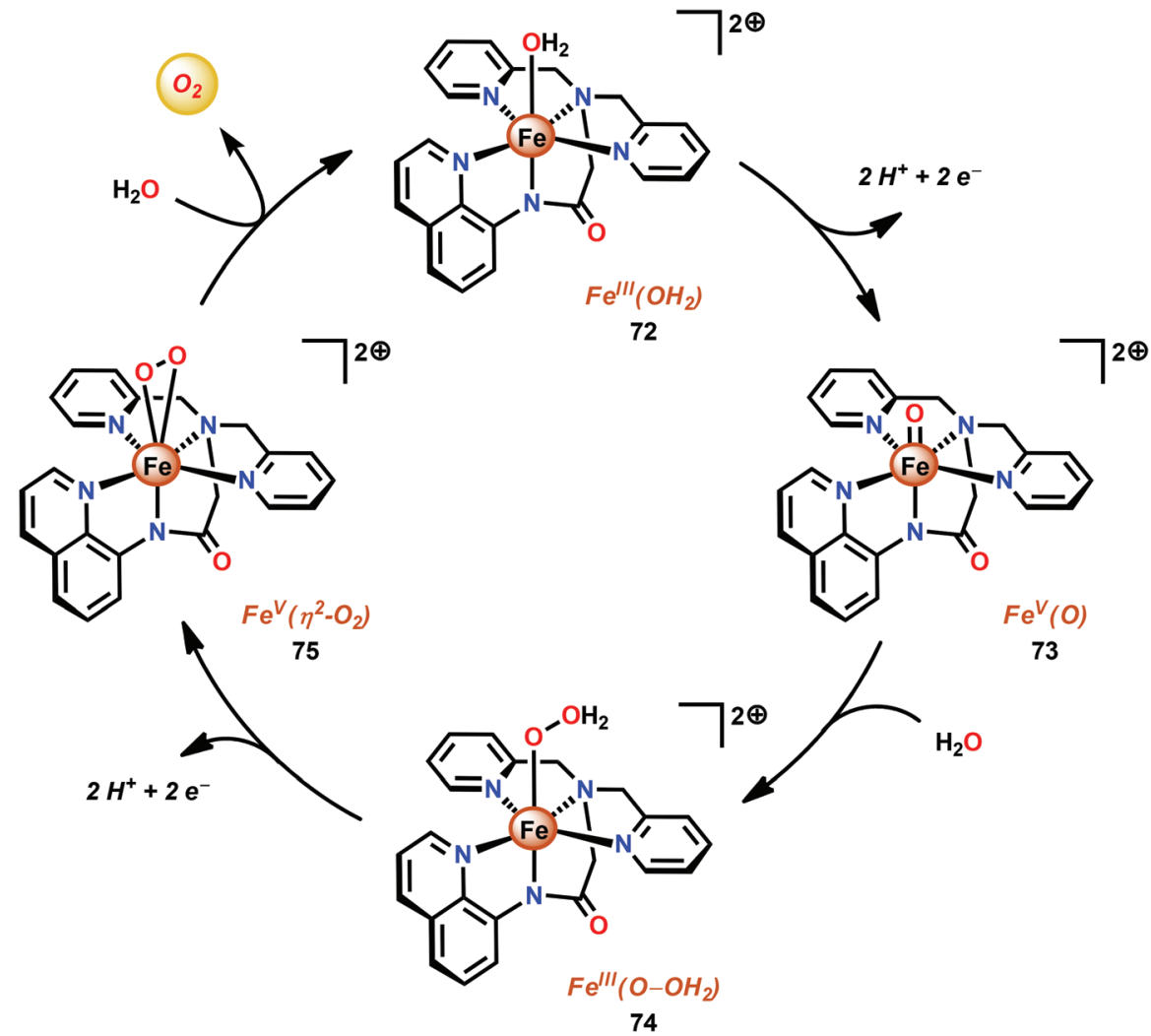

Scheme 6 Proposed mechanism for electrocatalytic $\mathrm{H}_{2} \mathrm{O}$ oxidation by the $\left[\mathrm{Fe}(\mathrm{dpaq})\left(\mathrm{OH}_{2}\right)\right]^{2+}$ complex 72 .
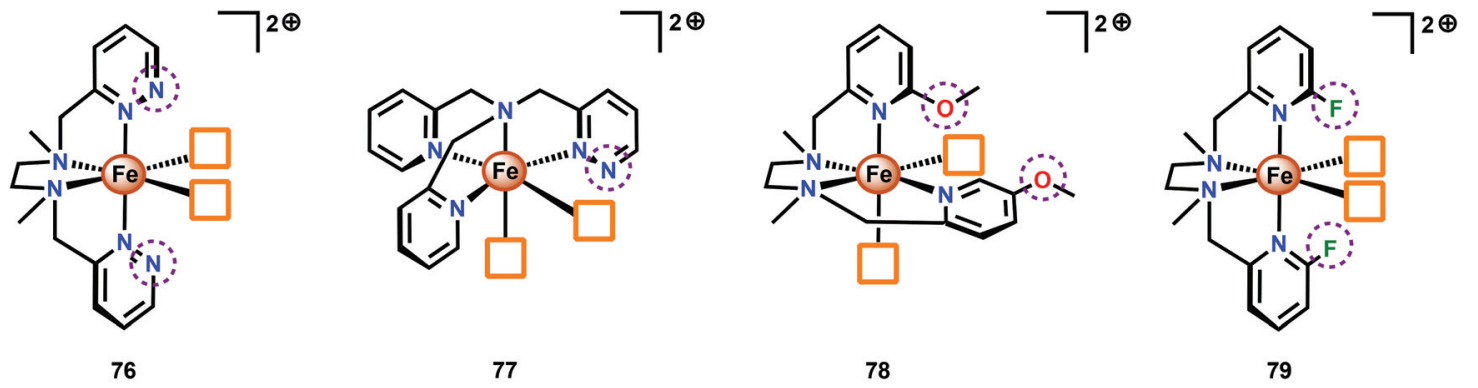

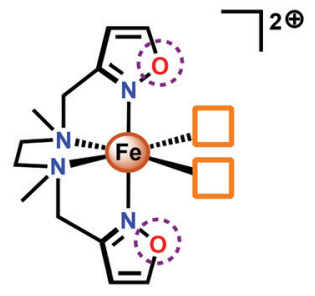

80

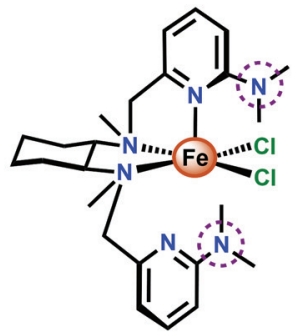

81

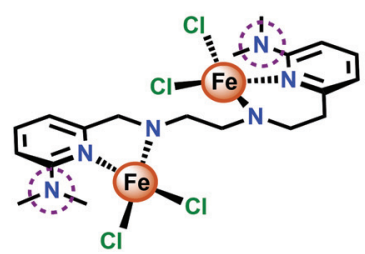

82

Fig. 31 Structures of Fe-based complexes 76-82 containing proton relays.

participate in PCET is an attractive feature for accessing improved Fe-based WOCs.

It needs to be stressed that the molecular nature of Fe-based complexes is highly dependent on the reaction conditions. $^{203}$ Additionally, the catalytic activity of Fe-based complexes and the formation of metal nanoparticles are extremely susceptible to electronic and structural features. This intricate behavior is elegantly illustrated by recent examinations 
conducted by the groups of Lau ${ }^{204}$ and Fukuzumi. ${ }^{205}$ In these studies, the Fe-based complexes were shown to act as homogeneous catalysts under more acidic conditions while more basic conditions facilitated the formation of $\mathrm{Fe}$-oxide nanoparticles.

The rational construction of ligand scaffolds, which allow high-valent Fe species to be generated and stabilized, still remains an essential challenge that needs to be addressed if more robust Fe-based catalysts are to be developed. As further insight into the mechanistic details of Fe-catalyzed $\mathrm{H}_{2} \mathrm{O}$ oxidation emerges, new ways to design more efficient Fe-based systems will most certainly be devised.

\subsection{Dinuclear Fe-based catalysts}

Although a variety of mononuclear Fe-based complexes have been shown to catalyze $\mathrm{H}_{2} \mathrm{O}$ oxidation, examples of dinuclear Fe complexes capable of mediating this transformation are currently limited. Initial observations on dinuclear Fe species being involved in the catalytic process were reported by Najafpour and co-workers. ${ }^{206}$ The authors selected the tris(2-pyridylmethyl)amine (tpa) ligand and synthesized the dinuclear $\mathrm{Fe}_{2}^{\mathrm{III}, \mathrm{III}}$ complex $\left[(\mathrm{tpa})\left(\mathrm{OH}_{2}\right) \mathrm{Fe}(\mu-\mathrm{O}) \mathrm{Fe}\left(\mathrm{OH}_{2}\right)(\mathrm{tpa})\right]^{4+}$ (83, Fig. 32) which contains a $\mu$-oxo bridge. When the dinuclear Fe complex 83 was examined as a WOC using $\mathrm{Ce}^{\mathrm{IV}}$ as a chemical oxidant, the rate for $\mathrm{O}_{2}$ evolution was found to be significantly higher ${ }^{206}$ than for its mononuclear analog $\mathbf{5 8}$ (see Fig. 27). ${ }^{190}$ The rate was found to be first order in both $\mathrm{Ce}^{\mathrm{IV}}$ and catalyst 83, suggesting that $\mathrm{O}-\mathrm{O}$ bond formation occurs within the dinuclear framework.

Subsequent studies on dinuclear Fe-based WOCs by the groups of Sakai ${ }^{207}$ and $\mathrm{Ma}^{197}$ also centered on using the tpa ligand. The group of Sakai synthesized the dinuclear $\mathrm{Fe}$ complex $\left[(\mathrm{tpa}) \mathrm{Fe}(\mu-\mathrm{O})\left(\mu-\mathrm{SO}_{4}\right) \mathrm{Fe}(\mathrm{tpa})\right]^{2+}(\mathbf{8 4})$ and established that it mediated $\mathrm{H}_{2} \mathrm{O}$ oxidation using $\mathrm{NaIO}_{4}$ as a chemical oxidant. DLS analysis suggested that the dinuclear Fe complex served as a homogeneous WOC and that Fe-oxide nanoparticles were not formed under the investigated reaction conditions. Kinetic experiments showed a first-order dependence on the catalyst concentration. Unexpectedly, the rate of $\mathrm{O}_{2}$ evolution exhibited a dramatic increase when the $\mathrm{pH}$ was decreased. Such an effect is uncommon since the rate-determining step is usually nucleophilic attack of $\mathrm{H}_{2} \mathrm{O}$ or coupling of two oxyl units. It was speculated that the observed rate enhancement could be due to reduced anation at low $\mathrm{pH}^{207} \mathrm{Ma}$ and co-workers subsequently investigated the catalytic activity of the $\mathrm{Fe}$ complex $[(\mathrm{tpa})(\mathrm{Cl}) \mathrm{Fe}(\mu-\mathrm{O}) \mathrm{Fe}(\mathrm{Cl})(\mathrm{tpa})]^{2+}(\mathbf{8 5})$. In aqueous acetate buffer solutions, using Oxone ${ }^{\circledR}$ as a chemical oxidant, Fe complex 85 exhibited high $\mathrm{O}_{2}$ evolution activity with TONs reaching 2380 and TOFs of $2.2 \mathrm{~s}^{-1}$. HRMS suggested that upon dissolution in acetate buffer solutions, the acetate bridged dinuclear Fe species $[(\mathrm{tpa}) \mathrm{Fe}(\mu-\mathrm{O})(\mu-\mathrm{OAc}) \mathrm{Fe}(\mathrm{tpa})]^{3+}$ was formed. This was proposed to be essential because the two free coordination sites are constrained in a cis fashion, allowing for efficient $\mathrm{H}_{2} \mathrm{O}$ oxidation. $^{197}$

Thummel and co-workers recently revealed that the dinuclear $\mathrm{Fe}_{2}^{\mathrm{III}, \mathrm{III}}$ complex $\left[(\mathrm{ppq})\left(\mathrm{OH}_{2}\right) \mathrm{Fe}(\mu-\mathrm{O}) \mathrm{Fe}(\mathrm{Cl})(\mathrm{ppq})\right]^{3+}(\mathbf{8 6}$, Fig. $33 ; \mathrm{ppq}=2$-( pyrid-2'-yl)-8-(1",10"-phenanthrolin-2"-yl)quinoline) was able to mediate $\mathrm{H}_{2} \mathrm{O}$ oxidation. ${ }^{208}$ The tetradentate ppq ligand was previously employed in the synthesis of a Cobased complex for $\mathrm{H}_{2}$ evolution. ${ }^{209}$ Treating $\mathrm{FeCl}_{3}$ with the ppq ligand afforded the $\mu$-oxo bridged dinuclear $\mathrm{Fe}_{2}^{\mathrm{III}, \mathrm{III}}$ complex 86 in $28 \%$ yield. Electrochemical analysis of Fe complex 86 revealed a reversible wave at $\sim 0.21 \mathrm{~V} v s$. NHE and another quasi-reversible wave at $\sim 0.69 \mathrm{~V}$. The first event could be assigned to a two-electron process and was tentatively attributed to the simultaneous oxidation of the two $\mathrm{Fe}^{\mathrm{III}}$ centers, $\mathrm{Fe}_{2}^{\mathrm{III}, \mathrm{III}} \rightarrow \mathrm{Fe}_{2}^{\mathrm{IV}, \mathrm{IV}}$. This produced $\left[\mathrm{Fe}^{\mathrm{IV}} \mathrm{Fe}^{\mathrm{IV}}-\mathrm{OH}_{2}\right]$ could undergo disproportionation with loss of two protons to afford a $\left[\mathrm{Fe}^{\mathrm{III}} \mathrm{Fe}^{\mathrm{V}}=\mathrm{O}\right]$ species. $\mathrm{H}_{2} \mathrm{O}$ oxidation was evaluated using $\mathrm{Ce}^{\mathrm{IV}}$ as a chemical oxidant. Upon addition of the oxidant to a solution of complex 86, rapid $\mathrm{O}_{2}$ evolution was observed. As a comparison, the mononuclear Fe complex 87 (Fig. 33) was synthesized and examined as a WOC. Although the mononuclear complex 87 was able to oxidize $\mathrm{H}_{2} \mathrm{O}$, the dinuclear $\mathrm{Fe}$ complex 86 was found to be more active, affording a TON of $\sim 1000$ and a TOF of $2.2 \mathrm{~s}^{-1}$. An essential question was whether the dinuclear Fe complex 86 retains its dimeric structure or whether it dissociates to yield a monomeric species in solution. UV-vis analysis and the apparent first-order dependence on the catalyst concentration suggested that the Fe complex remains intact during the catalytic oxidation. The involvement of

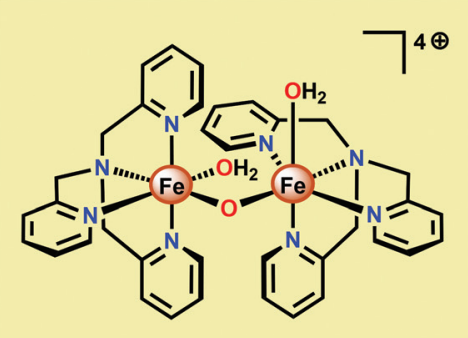

83

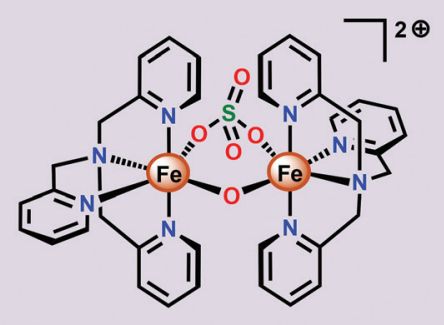

84

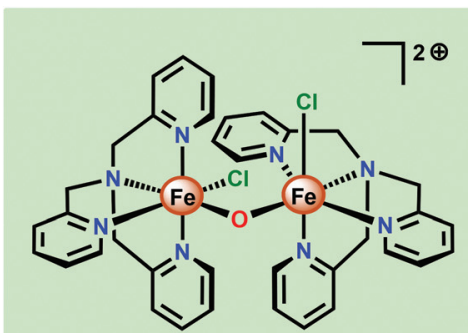

85

Fig. 32 Structures of the dinuclear Fe complexes $\left[(\mathrm{tpa})\left(\mathrm{OH}_{2}\right) \mathrm{Fe}(\mu-\mathrm{O}) \mathrm{Fe}\left(\mathrm{OH}_{2}\right)(\mathrm{tpa})\right]^{4+}(\mathbf{8 3}),\left[(\mathrm{tpa}) \mathrm{Fe}(\mu-\mathrm{O})\left(\mu-\mathrm{SO}{ }_{4}\right) \mathrm{Fe}(\mathrm{tpa})\right]^{2+}(\mathbf{8 4})$ and $[(\mathrm{tpa})(\mathrm{Cl}) \mathrm{Fe}(\mu-\mathrm{O}) \mathrm{Fe}$ $(\mathrm{Cl})(\mathrm{tpa})]^{2+}(85)$. 


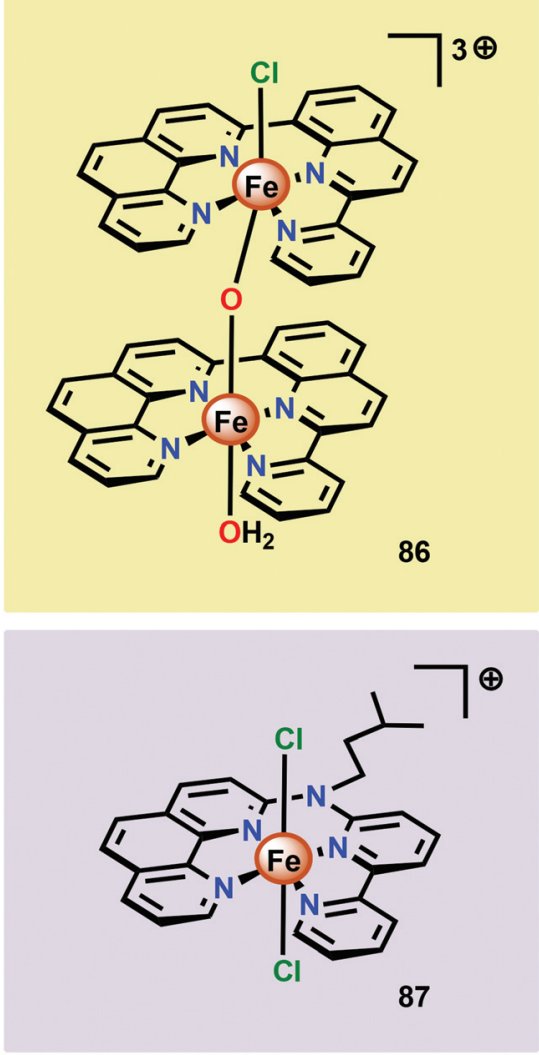

Fig. 33 Structure of the dinuclear $\left[(p p q)\left(\mathrm{OH}_{2}\right) \mathrm{Fe}(\mu-\mathrm{O}) \mathrm{Fe}(\mathrm{Cl})(\mathrm{ppq})\right]^{3+}$ complex 86 and the mononuclear Fe complex 87.

nanoparticles in the studied catalytic system could successfully be discarded based upon DLS measurements. ${ }^{208}$ The collective work on dinuclear Fe-based catalysts highlights that dinuclear species have the potential of generating more active catalytic systems compared to their mononuclear counterparts. The continued endeavors in this field will likely result in a rapid expansion of viable, and more robust, dinuclear Fe-based catalysts. This is further highlighted by the fact that a recently developed homogeneous pentanuclear Fe complex is able to facilitate $\mathrm{O}-\mathrm{O}$ bond formation with an impressive efficiency. $^{210}$

\section{Co-based systems for water oxidation}

Inorganic Co salts have been studied as potential WOCs since the late 1960s. ${ }^{175,211-213}$ Although these early attempts were rather unsuccessful due to precipitation of heterogeneous species, they suggested the involvement of $\mathrm{Co}^{\mathrm{IV}}$ species during the catalytic process. ${ }^{214}$ Spurred by the findings of Nocera and co-workers that $\mathrm{CoO}_{x}$ species ( $\mathrm{CoP}_{i}$ catalyst, Fig. 34), ${ }^{215-229}$ generated in situ under neutral conditions in phosphate buffer, exhibited $\mathrm{O}_{2}$ evolution activity, several research groups have attempted to prepare homogeneous molecularly defined Cobased catalysts for the oxidation of $\mathrm{H}_{2} \mathrm{O}$.

\subsection{Co polyoxometalates (POMs) - structurally defined all-inorganic catalysts}

In 2010, Hill and co-workers reported that Co-based polyoxometalates (POMs) were able to evolve $\mathrm{O}_{2}$ when driven by pregenerated or photochemically generated $\left[\mathrm{Ru}(\mathrm{bpy})_{3}\right]^{3+} \cdot{ }^{230-234}$ The all-inorganic Co-POM catalysts can be considered as the homogeneous alternative to metal oxides with the advantage of being well-defined and consisting of only inorganic elements. Prior to the report dealing with the Co-POMs, the groups of Hill and Bonchio had simultaneously shown that their $\mathrm{Ru}-$ analogs were efficient catalysts for the oxidation of $\mathrm{H}_{2} \mathrm{O} .{ }^{235,236}$ With the goal of developing an earth-abundant POM, Hill and co-workers synthesized the tetranuclear Co-POM $\left[\mathrm{Co}_{4}\left(\mathrm{OH}_{2}\right)_{2}\left(\alpha-\mathrm{PW}_{9} \mathrm{O}_{34}\right)_{2}\right]^{10-}(\mathbf{8 8}$, Fig. 35) and showed that it was capable of driving $\mathrm{H}_{2} \mathrm{O}$ oxidation with $\left[\mathrm{Ru}(\mathrm{bpy})_{3}\right]^{3+} \cdot{ }^{230}$ Subsequent studies revealed that Co-POM 88 also catalyzed photoinduced $\mathrm{H}_{2} \mathrm{O}$ oxidation using $\left[\mathrm{Ru}(\mathrm{bpy})_{3}\right]^{2+}$ as a photosensitizer and persulfate $\left(\mathrm{S}_{2} \mathrm{O}_{8}{ }^{2-}\right)$ as a sacrificial electron acceptor, generating a TON of 224 and a quantum yield of $30 \% .^{231} \mathrm{Co}-\mathrm{POM}$ 88's $\mathrm{H}_{2} \mathrm{O}$ oxidation activity and other essential features have also been studied by other research groups. ${ }^{237-240}$ A recent report by the Hill group has shown that the structurally analogous Co-POM $\left[\mathrm{Co}_{4}\left(\mathrm{H}_{2} \mathrm{O}\right)_{2}\left(\mathrm{VW}_{9} \mathrm{O}_{34}\right)_{2}\right]^{10-}$ is an extremely efficient WOC, reaching TOFs $>1000 \mathrm{~s}^{-1}$ with quantum yields approaching $68 \% .^{241}$ Additional Co-POM derivatives have also been synthesized by the Wang group and shown to mediate photocatalytic $\mathrm{H}_{2} \mathrm{O}$ oxidation. ${ }^{242}$
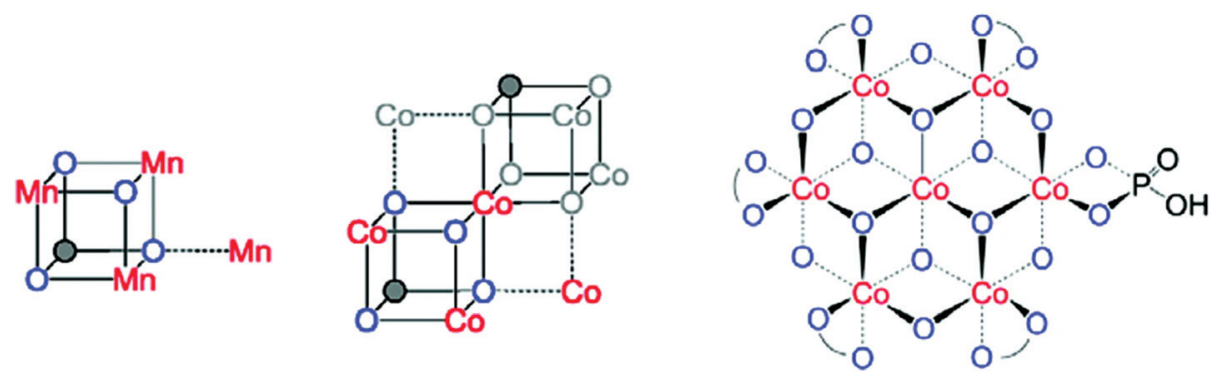

Fig. 34 (Left) Depiction of the $\mathrm{Mn}_{4} \mathrm{Ca}$ cluster in the OEC. (Middle) Structure of the $\mathrm{CoP}_{i}$ catalyst as determined by extended X-ray absorption fine structure (EXAFS). (Right) The $\mathrm{CoP}_{i}$ structure rotated by $45^{\circ}$ to highlight the edge sharing octahedra. Adapted with permission from ref. 225 . Copyright 2012 American Chemical Society. 


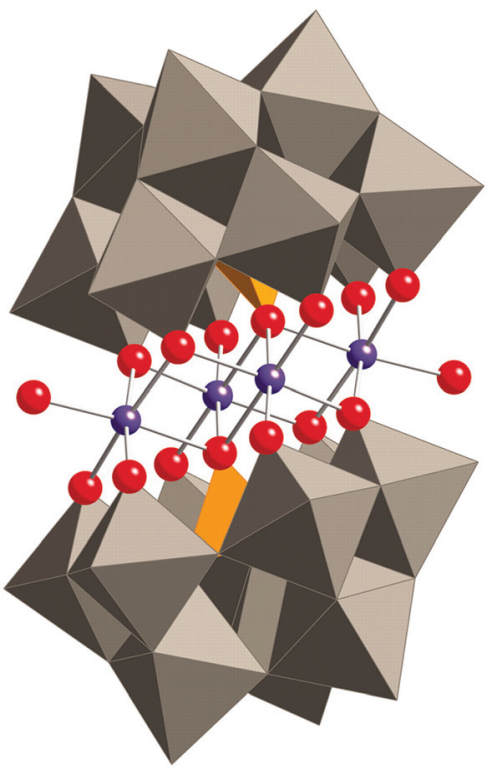

Fig. 35 Structure of the tetranuclear Co-POM $88 \quad\left(\left[\mathrm{CO}_{4}\left(\mathrm{OH}_{2}\right)_{2}-\right.\right.$ $\left.\left.\left(\alpha-\mathrm{PW}_{9} \mathrm{O}_{34}\right)_{2}\right]^{10-}\right)$. Reprinted with permission from ref. 230. Copyright 2010 American Association for the Advancement of Science.

The original report on Co-POM 88 contained a rigorous evaluation of whether the observed catalytic activity originated from the homogeneous Co-POM 88 or whether decomposition resulted in Co oxides which were the real catalytic entities. From these extensive experiments it was suggested that CoPOM 88 did not decompose and operated via a homogeneous mechanism. ${ }^{230}$ Although Hill and co-workers concluded that Co-POM 88 was stable under the studied reaction conditions, subsequent reports challenged these conclusions, showing that POM 88 decomposed to Co oxides as the dominant catalyst. $^{239,243}$ Additional studies revealed that the slight modifications of the reaction conditions influenced the operating mechanism and indicated that the conclusions from the original publication on Co-POM 88 were indeed correct. ${ }^{244,245}$ They further highlight that the homogeneity of WOCs is highly dependent on the reaction conditions, such as the buffer and $\mathrm{pH}$, which needs to be considered when determining the involvement of heterogeneous metal oxide species during catalysis. $^{246}$

The group of Galán-Mascarós subsequently reported on a high-nuclearity Co-POM, $\left[\mathrm{Co}_{9}(\mathrm{OH})_{3}\left(\mathrm{OH}_{2}\right)_{6}\left(\mathrm{HPO}_{4}\right)_{2}\left(\mathrm{PW}_{9} \mathrm{O}_{34}\right)_{3}\right]^{16-}$ (89, Fig. 36). ${ }^{247}$ The nonanuclear Co core is stabilized by three hydroxo and two hydrogen phosphate bridges. The nonanuclear Co-POM 89 was found to catalyze $\mathrm{H}_{2} \mathrm{O}$ oxidation using $\mathrm{NaClO}$ as a chemical oxidant. Experiments supported a homogeneous operating mechanism under chemical oxidation whereas slow release of Co was observed when electrochemical $\mathrm{H}_{2} \mathrm{O}$ oxidation was performed. However, formation of a Co oxide film on the electrode could be avoided by addition of excess 2,2'-bipyridine, which functions as a chelating agent for the liberated $\mathrm{Co}^{\mathrm{II}}$ or $\mathrm{Co}^{\mathrm{III}}$. A TON of $\sim 400$ and a TOF of $\sim 0.1$ were measured, with maintained $\mathrm{O}_{2}$ evolution activity for

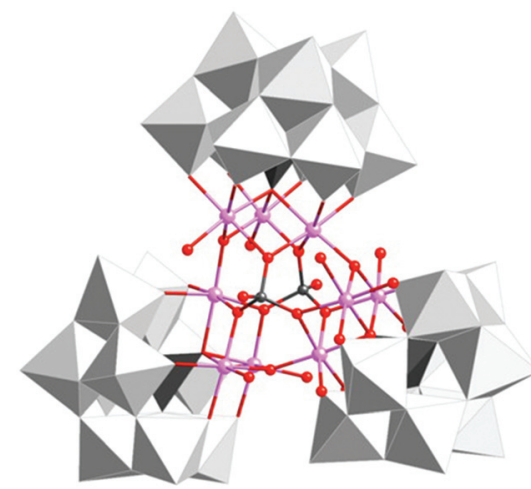

Fig. 36 Structure of the nonanuclear Co-POM $\left[\mathrm{CO}_{9}(\mathrm{OH})_{3}\left(\mathrm{OH}_{2}\right)_{6}-\right.$ $\left.\left(\mathrm{HPO}_{4}\right)_{2}\left(\mathrm{PW}_{9} \mathrm{O}_{34}\right)_{3}\right]^{16-}(89)$. Adapted with permission from ref. 247. Copyright 2012 American Chemical Society.

several days without any sign of fatigue or decomposition. ${ }^{247}$ The same group also synthesized an insoluble salt (Cs salt) of Co-POM 89 for integration into amorphous carbon paste electrodes. The catalytic activity of the modified electrodes was maintained in the solid state with constant rates for several hours. $^{248}$

Additional examples of Co-based POMs that have been reported to mediate visible-light driven $\mathrm{H}_{2} \mathrm{O}$ oxidation include the mixed dinuclear Co-POM $\left[\mathrm{Co}^{\mathrm{II}} \mathrm{Co}^{\mathrm{III}}\left(\mathrm{OH}_{2}\right) \mathrm{W}_{11} \mathrm{O}_{39}\right]^{7-}(\mathbf{9 0}),{ }^{249}$ the octanuclear Co-POM $\left[\left(\mathrm{A}-\alpha-\mathrm{SiW}_{9} \mathrm{O}_{34}\right)_{2} \mathrm{Co}_{8}(\mathrm{OH})_{6}\left(\mathrm{OH}_{2}\right)_{2}\left(\mathrm{CO}_{3}\right)_{3}\right]^{16-}$ $(\mathbf{9 1}){ }^{250}\left[\mathrm{Co}^{\mathrm{II}}(\mathrm{bpy})_{3}\right]_{6}\left(\mathrm{H}_{2} \mathrm{bpy}\right)\left[\left(\mathrm{Co}^{\mathrm{II}} \mathrm{bpy}\right)_{2}-\left(\mathrm{PMo}_{8}^{\mathrm{VI}} \mathrm{Mo}_{4}^{\mathrm{V}} \mathrm{O}_{40}\right)\right]_{3}\left[\left(\mathrm{Co}{ }^{\mathrm{II}} \mathrm{bpy}\right)-\right.$ $\left.\left(\mathrm{PMo}_{8}^{\mathrm{VI}} \mathrm{Mo}_{4}^{\mathrm{V}} \mathrm{O}_{40}\right)\right] \quad(92),{ }^{251} \quad\left[\mathrm{Co}_{2} \mathrm{Bi}_{2}\left(\alpha-\mathrm{B}-\mathrm{CoW}_{9} \mathrm{O}_{34}\right)_{2}\right]^{14-} \quad(93),{ }^{252}$ $\left[\mathrm{Co}_{2} \mathrm{Mo}_{10} \mathrm{O}_{38} \mathrm{H}_{4}\right]^{6-}(\mathbf{9 4})^{253}$ and $\left[\left\{\mathrm{Co}\left(\mathrm{OH}_{2}\right)_{3}\right\}_{2}\left\{\mathrm{CoBi}_{2} \mathrm{~W}_{19} \mathrm{O}_{66}(\mathrm{OH})_{4}\right\}\right]^{10-}$ (95). ${ }^{254}$ From the plethora of studies conducted on Co-based POMs, it is clear that these catalysts can operate as robust and efficient molecular catalytic entities for the oxidation of $\mathrm{H}_{2} \mathrm{O}$.

\subsection{Co cubanes as mimics of the catalytic core in the oxygen-evolving complex}

Inspired by the structural rearrangement of the $\mathrm{Mn}_{4} \mathrm{Ca}$ core in the OEC, researchers have devoted considerable efforts to synthesize complexes with similar cubane core structures. Early examples of such complexes include the Co cubanes $\mathrm{Co}_{4} \mathrm{O}_{4}(\mathrm{pyr})_{4}(\mathrm{OAc})_{4}(\mathbf{9 6})^{255,256}$ and $\left[\mathrm{Co}_{4} \mathrm{O}_{4}(\mathrm{bpy})_{4}(\mathrm{OAc})_{2}\right]^{2+}(\mathbf{9 7})$ (Fig. 37). ${ }^{257,258}$ The $\mathrm{Co}_{4} \mathrm{O}_{4}(\mathrm{pyr})_{4}(\mathrm{OAc})_{4}$ (96) cubane can be easily prepared from $\mathrm{Co}\left(\mathrm{NO}_{3}\right)_{2}$, NaOAc and pyridine and contains a $\mathrm{Co}_{4} \mathrm{O}_{4}$ core, which makes this cubane and related systems attractive as potential WOCs. A seminal report by Dismukes and co-workers showed that cubane $\mathbf{9 6}$ indeed was able to promote light-driven $\mathrm{H}_{2} \mathrm{O}$ oxidation using a threecomponent system consisting of $\left[\mathrm{Ru}(\mathrm{bpy})_{3}\right]^{2+}$ as a photosensitizer and $\mathrm{Na}_{2} \mathrm{~S}_{2} \mathrm{O}_{8}$ as a sacrificial electron acceptor. This photocatalytic system generated a TON of 40 and a TOF of $0.02 \mathrm{~s}^{-1} .^{259}$

Subsequent studies by Bonchio and co-workers involved the examination of isostructural analogs of Co cubane $96 .^{260,261}$ The authors targeted Co cubanes 98-103 (Fig. 38) in order to study catalyst tuning for boosting the photocatalytic efficiency in the three-component system previously used by Dismukes 


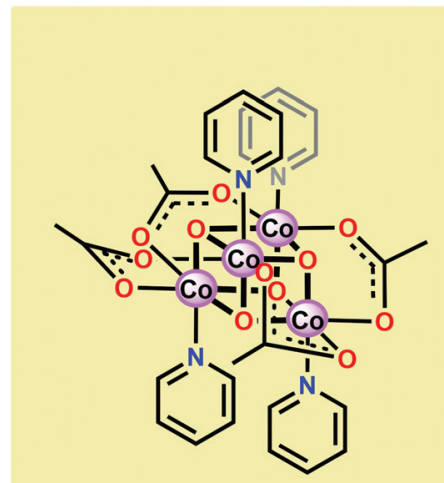

96
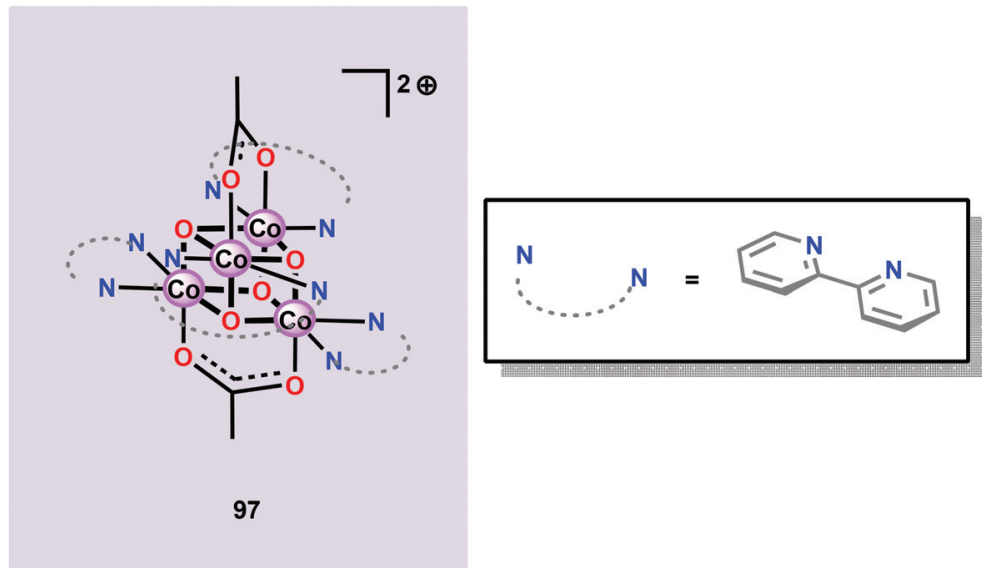

Fig. 37 Structure of Co cubanes $\mathrm{Co}_{4} \mathrm{O}_{4}(\text { pyr })_{4}(\mathrm{OAc})_{4}(96)$ and $\left[\mathrm{Co}_{4} \mathrm{O}_{4}(\mathrm{bpy})_{4}(\mathrm{OAc})_{2}\right]^{2+}(97)$.

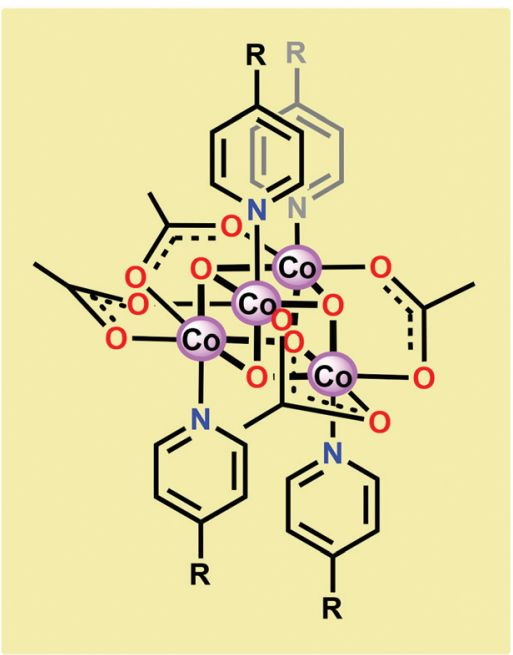

98: $\mathrm{R}=\mathrm{Me}$

99: $R={ }^{t} \mathrm{Bu}$

100: $R=O M e$

101: $\mathrm{R}=\mathrm{Br}$

102: $\mathrm{R}=\mathrm{CO}_{2} \mathrm{Me}$

103: $\mathrm{R}=\mathrm{CN}$

Fig. 38 Structures of Co cubanes 98-103.

and co-workers. Hammett linear free energy plots were employed and revealed a correlation between the photoinduced electron transfer constants and the electron-donating ability of the ligand. However, under the explored conditions all of the investigated cubanes reached similar TONs $(\sim 140)$, with the difference being the rate by which $\mathrm{O}_{2}$ was produced.

Ofoli and co-workers recently immobilized Co cubane 96 on ITO and showed that the cubane catalyst retained its catalytic activity similarly to the homogeneous catalytic entity. ${ }^{262}$ Sun and co-workers have also coupled Co cubane 96 to $\left[\mathrm{Ru}(\mathrm{bpy})_{3}\right]^{2+}$-type photosensitizers to generate two supramolecular assemblies, assembly $\mathbf{1 0 4}$ depicted in Fig. 39 and the cyclic assembly 105 consisting of two Co cubane and two $\left[\mathrm{Ru}(\mathrm{bpy})_{3}\right]^{2+}$ units (not shown). ${ }^{263}$ The carboxylate motif was chosen since it has been shown that Co cubane 96 can be immobilized onto carboxylate functionalized silica via carboxylate exchange. ${ }^{264}$

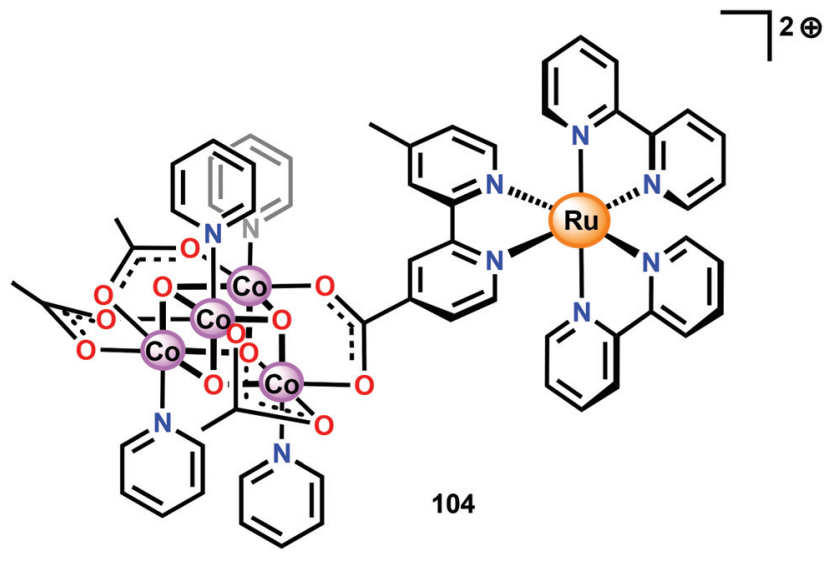

Fig. 39 Depiction of Ru-Co assembly 104.

Electrochemical measurements revealed that assembly 104 displayed two redox peaks at $1.01 \mathrm{~V}$ and $1.28 \mathrm{~V} v s$. NHE. The cyclic assembly 105 also exhibited two redox peaks; however, these were positively shifted and appeared at $1.10 \mathrm{~V}$ and $1.34 \mathrm{~V}$ vs. NHE. In comparison, a solution containing a mixture of the separate components, Co cubane 96 and $\left[\mathrm{Ru}(\mathrm{bpy})_{3}\right]^{2+}(\mathbf{1})$, displayed two waves at $0.91 \mathrm{~V}$ and $1.26 \mathrm{~V} v s$. NHE. The two assemblies were subsequently evaluated toward light-driven $\mathrm{H}_{2} \mathrm{O}$ oxidation using $\mathrm{Na}_{2} \mathrm{~S}_{2} \mathrm{O}_{8}$ as a sacrificial electron acceptor. When exposed to light, the two assemblies 104 and 105 rapidly evolved $\mathrm{O}_{2}$. Here, the cyclic assembly $\mathbf{1 0 5}$ proved to be a more efficient catalyst than assembly 104, producing a TOF of 0.023 $\mathrm{s}^{-1}$ compared to $0.0067 \mathrm{~s}^{-1}$ for the linear assembly 104 . Although the reason for the striking difference in activity for the cyclic assembly $\mathbf{1 0 5}$ is still not clear, the authors speculated that assembly $\mathbf{1 0 5}$ was more robust than the linear counterpart. This hypothesis originated from the fact that cyclic assembly 105 exhibited fewer changes in the UV-vis spectrum during the photocatalytic experiments compared to assembly $104 .^{263}$ 
A mechanistic investigation conducted by Tilley and coworkers on the $\mathrm{Co}_{4} \mathrm{O}_{4}(\mathrm{pyr})_{4}(\mathrm{OAc})_{4}$ cubane (96) suggested that the stoichiometric reaction of the one-electron oxidized cubane $\left(96^{+},\left[\mathrm{Co}_{3}^{\mathrm{III}} \mathrm{Co}^{\mathrm{IV}}\right]\right)$ with $\mathrm{OH}^{-}$produces $\mathrm{O}_{2}$ with quantitative regeneration of cubane 96. The experimental results also suggested that the $\mathrm{Co}_{3}^{\mathrm{III}} \mathrm{Co}^{\mathrm{IV}}$ species $\left(\mathbf{9 6}^{+}\right)$undergoes disproportionation to generate an intermediate with an even higher oxidation state, a formal $\mathrm{Co}_{3}^{\mathrm{III}} \mathrm{Co}^{\mathrm{V}}$ or $\mathrm{Co}_{2}^{\mathrm{III}} \mathrm{Co}_{2}^{\mathrm{IV}}$ species. The proposed mechanism for the reduction of $9^{+}$by $\mathrm{OH}^{-}$is depicted in Scheme $7 .^{265}$ The mechanism by which Co cubanes mediate $\mathrm{H}_{2} \mathrm{O}$ oxidation has also been investigated by density functional theory (DFT) calculations. ${ }^{266,267}$ Several reaction pathways were considered; however, the lowest energy pathway for Co cubane $\mathbf{9 6}$ was found to proceed through a formal $\mathrm{Co}^{\mathrm{V}}$ species, which is perhaps better described as a $\mathrm{Co}^{\mathrm{IV}}$ center coupled to an oxygen radical. The mechanism with the lowest energy involved water nucleophilic attack on the formed oxygen radical. ${ }^{266}$ In a related study, the pathway was observed to involve germinal coupling of a formal $\mathrm{Co}^{\mathrm{v}}$-oxo unit with bridging oxo sites. In this study the examined models were revealed to be sensitive to positions of the ligands and the hydrogen bonding environment, resulting in distinct isomers with different energies. ${ }^{267,268}$ The studies described above highlight the necessity of designing Co cubanes, and other Co-based WOCs, that are capable of accessing highvalent redox states. A multimetallic system is well-suited to stabilize such high redox states but is not a prerequisite for designing active Co-based WOCs since the ancillary ligands can also be an essential feature for tuning the redox potentials of the metal complexes.

Co cubane $\left[\mathrm{Co}_{4}^{\mathrm{II}}(\mathrm{hmp})_{4}(\mu-\mathrm{OAc})_{2}\left(\mu_{2}-\mathrm{OAc}\right)_{2}\left(\mathrm{H}_{2} \mathrm{O}\right)_{2}\right] \quad$ (112, Fig. 40 ; hmp = 2-(hydroxymethyl)pyridine) was synthesized by

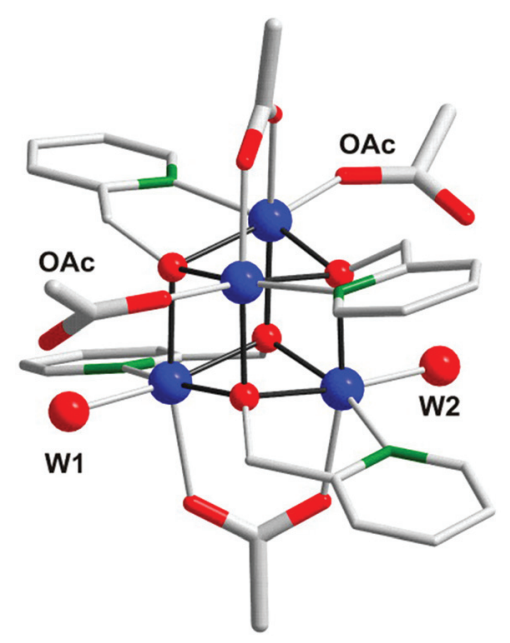

Fig. 40 Crystal structure of Co cubane $\left[\mathrm{Co}_{4}^{\prime \prime}(\mathrm{hmp})_{4}(\mu-\mathrm{OAc})_{2}\left(\mu_{2}-\right.\right.$ $\mathrm{OAc})_{2}\left(\mathrm{H}_{2} \mathrm{O}\right)_{2}$ ] (112). Co, blue; $\mathrm{O}$, red; $\mathrm{N}$, green; $\mathrm{C}$, gray; $\mathrm{H}$ atoms are omitted for clarity. Adapted with permission from ref. 269. Copyright 2013 American Chemical Society.

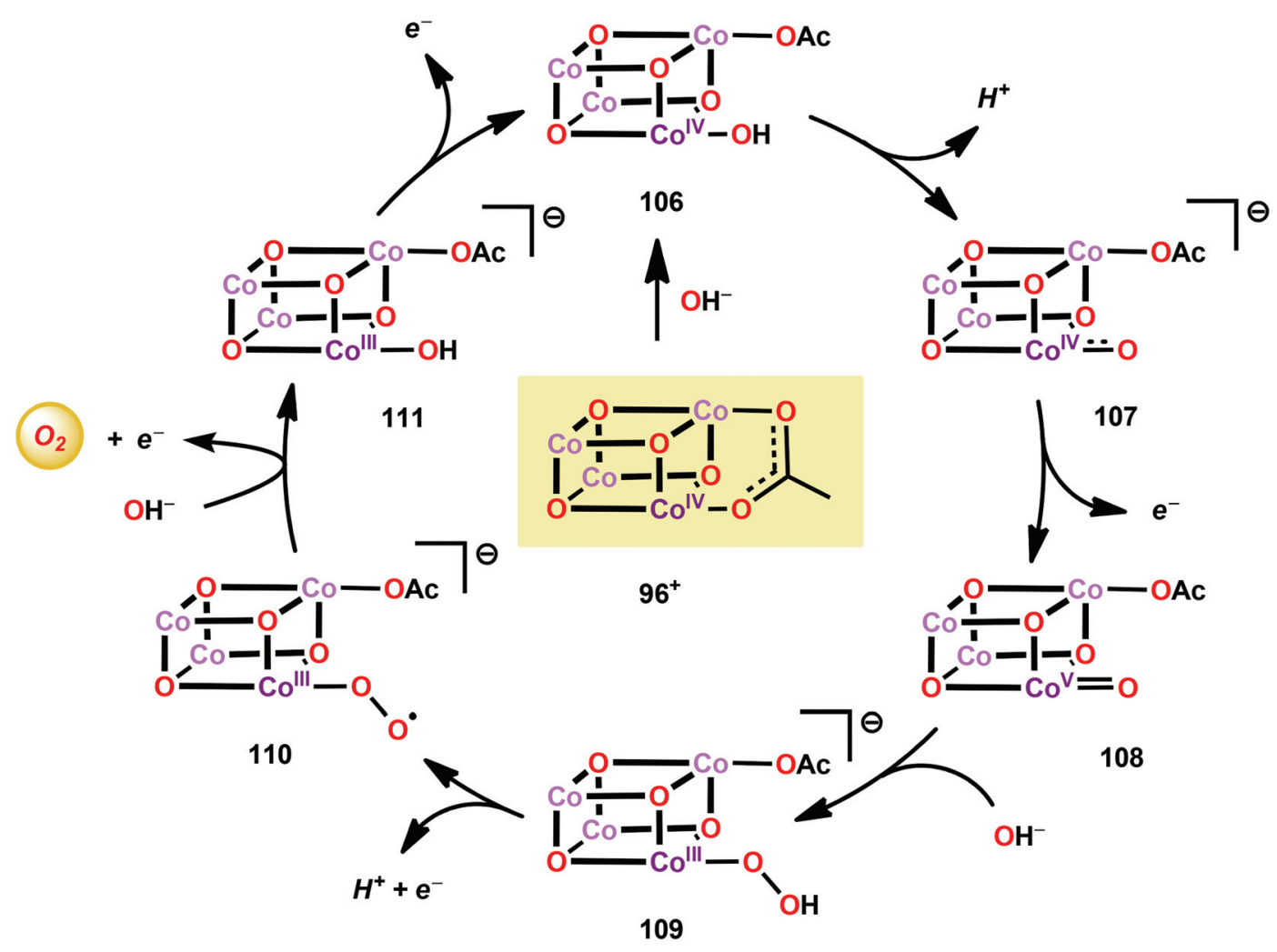

Scheme 7 Proposed mechanism for the reaction of cubane $96^{+}$with $\mathrm{OH}^{-}$. 
Patzke and co-workers as the first $\mathrm{Co}^{\mathrm{II}}$-based cubane WOC. ${ }^{269}$ The catalytic activity of Co cubane $\mathbf{1 1 2}$ was evaluated in lightdriven $\mathrm{H}_{2} \mathrm{O}$ oxidation using $\left[\mathrm{Ru}(\mathrm{bpy})_{3}\right]^{2+}$ as a photosensitizer and $\mathrm{Na}_{2} \mathrm{~S}_{2} \mathrm{O}_{8}$ as a sacrificial electron acceptor. From these experiments it was established that the $\mathrm{O}_{2}$ evolution performance was strongly dependent on the $\mathrm{pH}$. The TOF was shown to change notably over the studied $\mathrm{pH}$ range, from $1.8 \mathrm{~s}^{-1}$ at $\mathrm{pH} 7$ to $7 \mathrm{~s}^{-1}$ at $\mathrm{pH}$ 9. Several different techniques were used to determine the extent of nanoparticle formation and suggested that the Co cubane core of $\mathbf{1 1 2}$ remains intact. The high catalytic activity of Co cubane $\mathbf{1 1 2}$ was attributed to its flexible architecture consisting of monodentate acetate and aqua ligands in combination with a robust core. A recent computational study suggests that $\mathrm{O}-\mathrm{O}$ bond formation occurs either through a single-site pathway involving $\mathrm{H}_{2} \mathrm{O}$ attack on a Cooxo species or through an oxo-oxo coupling pathway. ${ }^{270}$

Subsequent work on biomimetic Co cubanes consisted of the synthesis and examination of a series of isostructural Co cubanes (113-116) with the general formula $\left[\mathrm{Co}_{3}^{\mathrm{II}} \mathrm{Ln}(\mathrm{hmp})_{4}(\mathrm{OAc})_{5} \mathrm{H}_{2} \mathrm{O}\right]$ (Fig. 41, where $\mathrm{Ln}=\mathrm{Ho}$, Er, Tm, Yb). ${ }^{271}$ These bioinspired Co cubanes show several design features, such as ligand flexibility and redox-inert $\mathrm{Ln}^{3+}$ metal ions for electrochemical tuning. The catalytic performance of the lanthanide cubane series (113-116) was studied using $\left[\mathrm{Ru}(\mathrm{bpy})_{3}\right]^{2+}$ as a photosensitizer and $\mathrm{Na}_{2} \mathrm{~S}_{2} \mathrm{O}_{8}$ as a sacrificial electron acceptor in order to enable a direct comparison with the previously developed Co cubane 112. $\mathrm{O}_{2}$ evolution peaked at $\mathrm{pH}$ 8-9, which was also observed for the $\left[\mathrm{Co}_{4}^{\mathrm{II}}(\mathrm{hmp})_{4}{ }^{-}\right.$ $\left.(\mu \text {-OAc })_{2}\left(\mu_{2}-\mathrm{OAc}\right)_{2}\left(\mathrm{H}_{2} \mathrm{O}\right)_{2}\right]$ cubane (112). Table 1 summarizes the catalytic activity of the biomimetic lanthanide cubanes $\left[\mathrm{Co}_{3}^{\mathrm{II}} \mathrm{Ln}(\mathrm{hmp})_{4}(\mathrm{OAc})_{5} \mathrm{H}_{2} \mathrm{O}\right]$. The stability of the lanthanide containing Co cubanes was subsequently assessed employing a variety of different techniques, including UV-vis aging tests, DLS, and extended X-ray absorption fine structure (EXAFS) and $\mathrm{X}$-ray absorption near-edge structure (XANES) solution phase

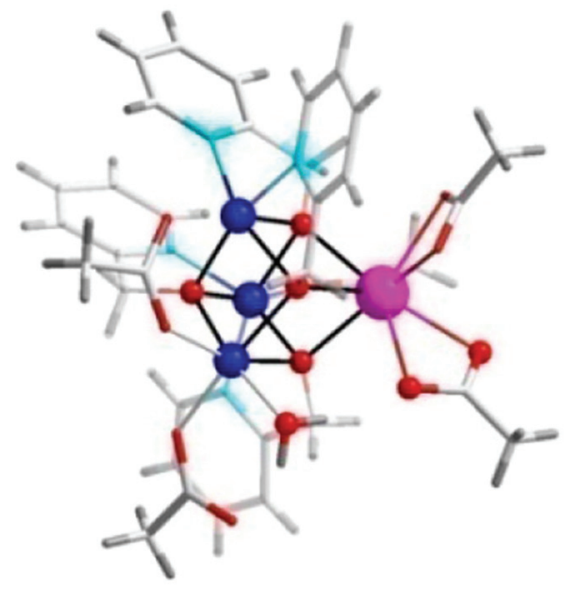

Fig. 41 Representative crystal structure of Co cubanes [Co ${ }_{3} \mathrm{Ln}$ $(\mathrm{hmp})_{4}(\mathrm{OAc})_{5} \mathrm{H}_{2} \mathrm{O}$ ] (where $\mathrm{Ln}=\mathrm{Ho}, \mathrm{Er}, \mathrm{Tm}, \mathrm{Yb}$ ). Co, blue; Ln, pink; O, red; $\mathrm{C}$, white; $\mathrm{H}$, gray. Adapted with permission from ref. 271. Copyright 2015 American Chemical Society.
Table 1 Comparison of photocatalytic $\mathrm{H}_{2} \mathrm{O}$ oxidation activities for Co cubanes 113-116 over the $\mathrm{pH}$ range 7-9

\begin{tabular}{|c|c|c|c|}
\hline $\mathrm{pH}$ & Catalyst concentration $(\mu \mathrm{M})$ & TON & $\operatorname{TOF}\left(\mathrm{s}^{-1}\right)$ \\
\hline \multicolumn{4}{|c|}{$\left[\mathrm{Co}_{3}^{\mathrm{II}} \mathrm{Ho}(\mathrm{hmp})_{4}(\mathrm{OAc})_{5} \mathrm{H}_{2} \mathrm{O}\right](113)$} \\
\hline $7^{a}$ & 12 & 7 & 0.87 \\
\hline $8^{b}$ & 10 & 163 & 5.84 \\
\hline $9^{c}$ & 12 & 135 & 9.55 \\
\hline \multicolumn{4}{|c|}{$\left[\mathrm{Co}_{3}^{\mathrm{II}} \mathrm{Er}(\mathrm{hmp})_{4}(\mathrm{OAc})_{5} \mathrm{H}_{2} \mathrm{O}\right](114)$} \\
\hline $7^{a}$ & 12 & 2 & 2.06 \\
\hline $8^{b}$ & 10 & 211 & 5.65 \\
\hline $9^{c}$ & 12 & 108 & 5.02 \\
\hline \multicolumn{4}{|c|}{$\left[\mathrm{Co}_{3}^{\mathrm{II}} \mathrm{Tm}(\mathrm{hmp})_{4}(\mathrm{OAc})_{5} \mathrm{H}_{2} \mathrm{O}\right](115)$} \\
\hline $7^{a}$ & 12 & 24 & 1.55 \\
\hline $8^{b}$ & 10 & 92 & 5.34 \\
\hline $9^{c}$ & 12 & 64 & 3.48 \\
\hline \multicolumn{4}{|c|}{$\left[\mathrm{Co}_{3}^{\mathrm{II}} \mathrm{Yb}(\mathrm{hmp})_{4}(\mathrm{OAc})_{5} \mathrm{H}_{2} \mathrm{O}\right](116)$} \\
\hline $7^{a}$ & 12 & 1.1 & 1.08 \\
\hline $8^{b}$ & 10 & 160 & 6.54 \\
\hline $9^{c}$ & 12 & 120 & 5.65 \\
\hline
\end{tabular}

${ }^{a}$ Photochemical experiments were carried out with a catalyst $(12 \mu \mathrm{M})$, $\left[\mathrm{Ru}(\mathrm{bpy})_{3}\right] \mathrm{Cl}_{2}(1 \mathrm{mM})$ and $\mathrm{Na}_{2} \mathrm{~S}_{2} \mathrm{O}_{8}(5 \mathrm{mM})$ in aqueous phosphate buffer solutions ( $\mathrm{pH} \quad 7,40 \mathrm{mM} \quad \mathrm{Na}_{2} \mathrm{HPO}_{4} / \mathrm{NaH}_{2} \mathrm{PO}_{4}$ buffer). ${ }^{b}$ Experiments were performed with a catalyst $(10 \mu \mathrm{M}),\left[\mathrm{Ru}(\mathrm{bpy})_{3}\right] \mathrm{Cl}_{2}$ (1 mM) and $\mathrm{Na}_{2} \mathrm{~S}_{2} \mathrm{O}_{8}(5 \mathrm{mM})$ in aqueous borate buffer solutions ( $\mathrm{pH} 8$, adjusted with $\mathrm{HCl}$ addition to $50 \mathrm{mM}$ borate buffer). ${ }^{c}$ Experiments were performed with a catalyst $(12 \mu \mathrm{M}),\left[\mathrm{Ru}(\mathrm{bpy})_{3}\right] \mathrm{Cl}_{2}(1 \mathrm{mM})$ and $\mathrm{Na}_{2} \mathrm{~S}_{2} \mathrm{O}_{8}(5 \mathrm{mM})$ in aqueous borate buffer solutions ( $\mathrm{pH}$ 9, adjusted with $\mathrm{HCl}$ addition to $50 \mathrm{mM}$ borate buffer).

tests, which supported the structural integrity of the $\left[\mathrm{Co}_{3}^{\mathrm{II}} \mathrm{Ln}\right.$ $\left.(\mathrm{hmp})_{4}(\mathrm{OAc})_{5} \mathrm{H}_{2} \mathrm{O}\right]$ cubane core under the catalytic conditions.

Although the stability of the various Co cubane WOCs was assessed and pointed to a homogeneous $\mathrm{H}_{2} \mathrm{O}$ oxidation pathway operating with the cubane core being intact, a report from the Nocera group suggested that the catalytic activity emanates from a $\mathrm{Co}^{\mathrm{II}}$ impurity. The $\mathrm{Co}^{\mathrm{II}}$ impurity was proposed to act as a source for the generation of heterogeneous Co species that are the real catalysts. These heterogeneous species are believed to be formed if the potential is sufficiently high to oxidize the $\mathrm{Co}^{\mathrm{II}}$ to $\mathrm{Co}^{\mathrm{III}}$ in the presence of a proton accepting electrolyte, such as phosphate and carbonate. ${ }^{272}$ A recent report also questions the homogeneity of the Co-based cubane complexes, and highlights the dependence on the initial structure and the catalytic methodology being used. ${ }^{273}$

From the conflicting results regarding the homogeneity of Co cubanes it is clear that care must be exercised when examining whether a specific WOC operates through a homogeneous mechanism or whether heterogeneous species are produced in situ, and the studied molecular complex merely acts as a precursor. However, deriving a definite conclusion for the examined catalytic system is not always straightforward and can be highly sensitive to the methodologies and experimental conditions being employed.

\subsection{Mononuclear Co catalysts}

The early observation that $\mathrm{Co}^{\mathrm{IV}}$ species could be involved in the catalytic oxidation of $\mathrm{H}_{2} \mathrm{O}$ using simple inorganic salts ${ }^{214}$ 
suggested that one key to realizing molecular Co WOCs might be to design ligands that permit stabilization of high-valent Co intermediates. Two seminal reports by the groups of Berlinguette $^{274}$ and Nocera ${ }^{275}$ showed that this principle was indeed

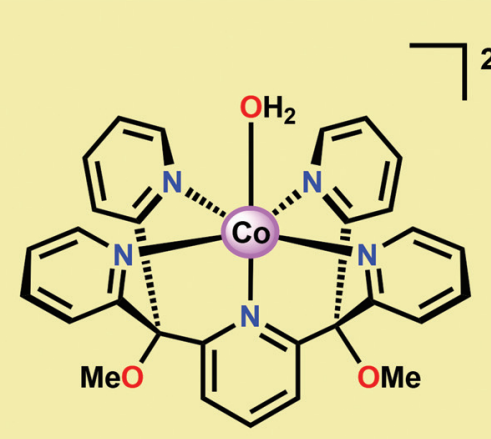

117

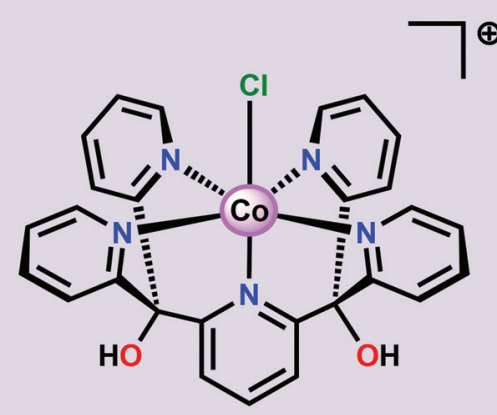

118

Fig. 42 Structures of Co-based complexes $\left[\mathrm{Co}(\mathrm{Py} 5)\left(\mathrm{OH}_{2}\right)\right]^{2+}(117)$ and $[\mathrm{Co}(\mathrm{Py} 5 \mathrm{OH})(\mathrm{Cl})]^{+}(118)$. viable. Berlinguette and co-workers utilized the pyridine-based pentacoordinating ligand Py5, ${ }^{126,127}$ giving Co-based complex $\left[\mathrm{Co}(\mathrm{Py} 5)\left(\mathrm{OH}_{2}\right)\right]^{2+}(\mathbf{1 1 7}$, Fig. 42$)$ with a single open coordination site. The Py5 ligand was chosen as the authors envisioned it to be a good motif for withstanding the harsh oxidative conditions needed to carry out oxidation of $\mathrm{H}_{2} \mathrm{O}$. Furthermore, the Py5 ligand lacks $\beta$-hydrogens, which prevents that the corresponding metal complex undergoes undesirable elimination processes. Electrochemical measurements showed that Co complex 117 displayed two redox events. The second event results in a significant rise in the current, suggesting that a catalytic reaction takes place. The catalytic current was demonstrated to increase with decreasing scan rate $(\nu)$, attesting that a chemical process, such as $\mathrm{O}-\mathrm{O}$ bond formation, is the ratedetermining step. The authors attributed this event to nucleophilic attack of $\mathrm{H}_{2} \mathrm{O}$ on a high-valent formal $\mathrm{Co}^{\mathrm{IV}}$-oxo/hydroxo species, generated after the initial two redox steps. ${ }^{274} \mathrm{~A}$ subsequent study conducted on the $\left[\mathrm{Co}(\mathrm{Py} 5)\left(\mathrm{OH}_{2}\right)\right]^{2+}$ complex 117 supported that the catalytic current was molecular in origin and that the $\mathrm{H}_{2} \mathrm{O}$ oxidation did not emanate exclusively from in situ formed heterogeneous Co species. ${ }^{276} \mathrm{~A}$ detailed computational mechanistic study on Co complex 117 suggested that the resting state of the catalyst contained a $\mathrm{Co}^{\mathrm{IV}}-$ oxyl species. The O-O bond formation was suggested to proceed via nucleophilic attack of $\mathrm{OH}^{-}$on this formal $\mathrm{Co}^{\mathrm{IV}}$-oxyl species. ${ }^{277}$ The structurally related $\mathrm{Co}^{\mathrm{II}}$ complex $[\mathrm{Co}(\mathrm{Py} 5 \mathrm{OH})(\mathrm{Cl})]^{+} \quad(\mathbf{1 1 8}$, Fig. 42) has also recently been reported to mediate $\mathrm{H}_{2} \mathrm{O}$ oxidation. $^{278}$

Based on previous observations that $\mathrm{Co}^{\mathrm{II}}$ hangman porphyrin complexes were able to activate $\mathrm{O}_{2},{ }^{279}$ Nocera and coworkers decided to investigate whether the related $\mathrm{Co}^{\mathrm{III}}$ corrole complexes 119 and 120 (Fig. 43) could promote the opposite reaction-oxidation of $\mathrm{H}_{2} \mathrm{O} .^{275}$ These $\mathrm{Co}$ xanthene hangman corrole complexes have two vacant coordination sites and contain a proximal base. Measurements revealed that they could indeed drive $\mathrm{H}_{2} \mathrm{O}$ oxidation electrochemically, with the $\beta$-octafluoro Co complex 120 being the more active of the two

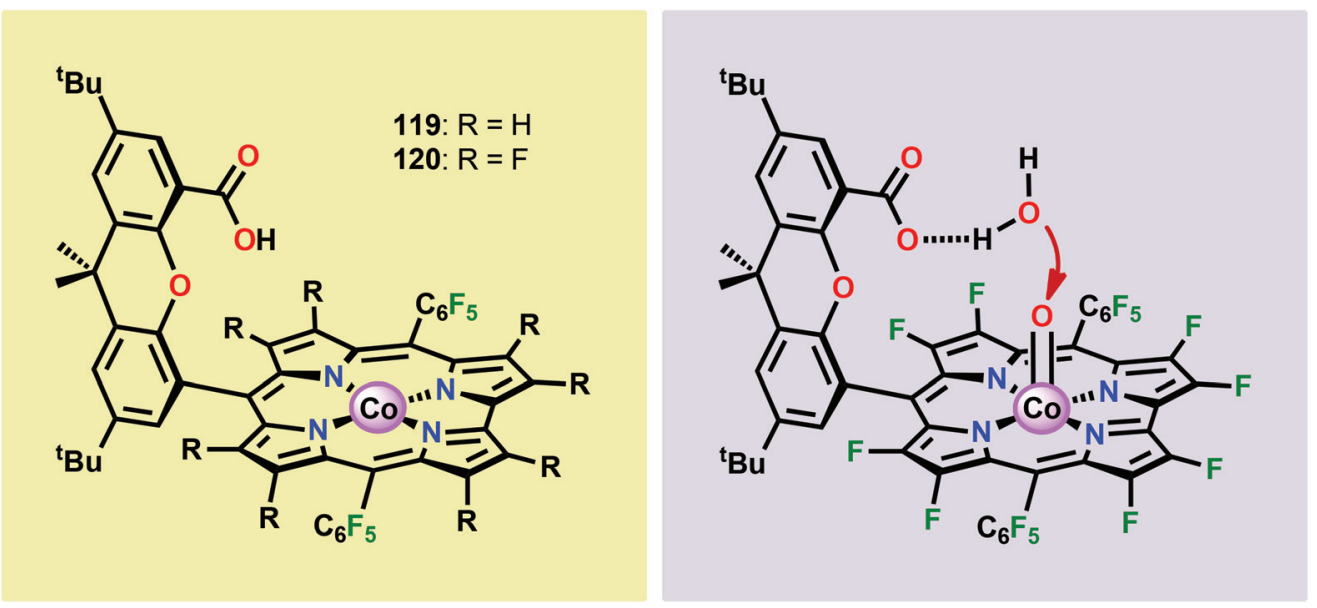

Fig. 43 (Left) Co corrole complexes 119 and 120, and (right) organization of $\mathrm{H}_{2} \mathrm{O}$ within the Co hangman cleft. 
complexes. The importance of the hangman cleft is believed to be its ability to arrange one $\mathrm{H}_{2} \mathrm{O}$ molecule in the primary coordination sphere of the Co center and another molecule in the secondary coordination sphere via hydrogen bonding to the xanthene hangman motif (see Fig. 43). ${ }^{275}$ Subsequent quantum chemical modeling supported the feature of the carboxylate unit in functioning as a general base to activate the attack of the incoming $\mathrm{H}_{2} \mathrm{O}$ molecule on the metal-oxo species. Additional key features in the catalytic cycle that were uncovered included the non-innocent role of the corrole backbone and that fluorination of the ligand backbone modulates the electrophilicity of the metal-oxo moiety and alleviates the decomposition of the produced corrole radical cations. ${ }^{280,281}$

Another Co corrole complex that has been reported to catalyze electrocatalytic $\mathrm{H}_{2} \mathrm{O}$ oxidation is $\left[\mathrm{Co}(\mathrm{tpfc})(\mathrm{pyr})_{2}\right]$ (121, Fig. 44; where tpfc $=5,10,15$-tris(pentafluorophenyl)corrole and pyr $=$ pyridine $).{ }^{282}$ Stability tests suggested that Co corrole 121 did operate through a homogeneous mechanism. The catalytic rate of $\mathrm{H}_{2} \mathrm{O}$ oxidation for Co complex 121 was enhanced by increasing the phosphate concentration, indicative of the importance of proton transfer for $\mathrm{O}-\mathrm{O}$ bond formation, which was also calculated to constitute the ratedetermining step.

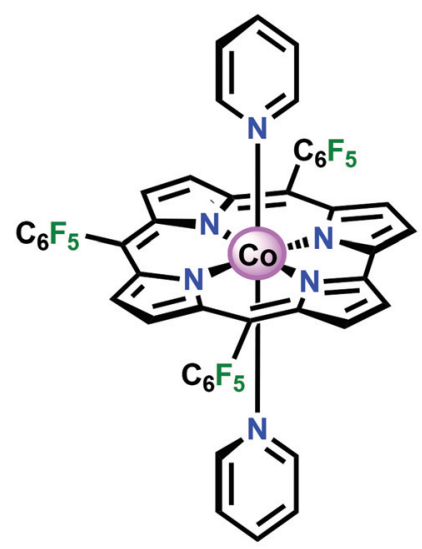

121

Fig. 44 Structure of Co corrole complex $\left[\mathrm{Co}(\mathrm{tpfc})(\mathrm{pyr})_{2}\right] 121$. tpfc = 5,10,15-tris (pentafluorophenyl)corrole, $\mathrm{pyr}=$ pyridine.
Co porphyrins have also been employed as WOCs and are depicted in Fig. 45. ${ }^{283,284}$ Sakai and co-workers recently reported that Co porphyrins $\mathbf{1 2 2 - 1 2 4}$ could function as active WOCs in photochemical oxidation of $\mathrm{H}_{2} \mathrm{O}$. Of the studied catalysts, Co porphyrin $\mathbf{1 2 4}$ was found to be the most efficient one (see Table 2). DLS measurements were also carried out to provide information whether nanoparticles are generated during the course of the catalysis. After the reactions, the solutions did not show any dispersion due to nanoparticle formation upon irradiation, which is in contrast to $\left[\mathrm{Co}(\mathrm{bpy})_{3}\right]^{2+}$ that was shown to efficiently produce nanoparticles when irradiated. The second order catalyst dependence suggests a bimolecular radical coupling event as the rate-determining step. Two pathways for $\mathrm{O}-\mathrm{O}$ bond formation were therefore proposed (Scheme 8), which featured either radical coupling of two formal $\mathrm{Co}^{\mathrm{IV}}$-oxyl or two $\mathrm{Co}^{\mathrm{III}}$-oxyl species, generated from the disproportionation of two $\mathrm{Co}^{\mathrm{IV}}$ species. $^{283}$

Although nanoparticle formation was not observed for Co porphyrins 122-124, the catalytic activity of these catalysts diminished significantly in subsequent runs after addition of fresh $\mathrm{Na}_{2} \mathrm{~S}_{2} \mathrm{O}_{8}$. The authors attributed this effect to decomposition of the Co porphyrins into catalytically less active or inactive entities. However, these entities must still contain the Co center; otherwise nanoparticles should have been observed. Mass spectrometry analysis of the reaction products revealed that oxidative cleavage of the porphyrin rings occurs at the meso positions, which produces species such as 134 (Fig. 46). ${ }^{283}$

In a previous report, meso-substituted Co porphyrin complexes have been shown to react with singlet oxygen $\left({ }^{1} \mathrm{O}_{2}\right)$, which is a powerful oxidant produced during $\mathrm{H}_{2} \mathrm{O}$ oxi-

Table 2 Photochemical $\mathrm{O}_{2}$ evolution by Co porphyrins $122-124^{a}$

\begin{tabular}{lrr}
\hline Catalyst & TON & TOF \\
\hline Co porphyrin 122 & 88.7 & 0.118 \\
Co porphyrin 123 & 103.4 & 0.138 \\
Co porphyrin 124 & 121.8 & 0.170
\end{tabular}

${ }^{a}$ Photochemical experiments were carried out with a catalyst $(10 \mu \mathrm{M})$, $\left[\mathrm{Ru}(\mathrm{bpy})_{3}\right]\left(\mathrm{NO}_{3}\right)_{2}(1 \mathrm{mM})$ and $\mathrm{Na}_{2} \mathrm{~S}_{2} \mathrm{O}_{8}(5 \mathrm{mM})$ in aqueous phosphate buffer solutions $(0.1 \mathrm{M}, \mathrm{pH} 11)$.
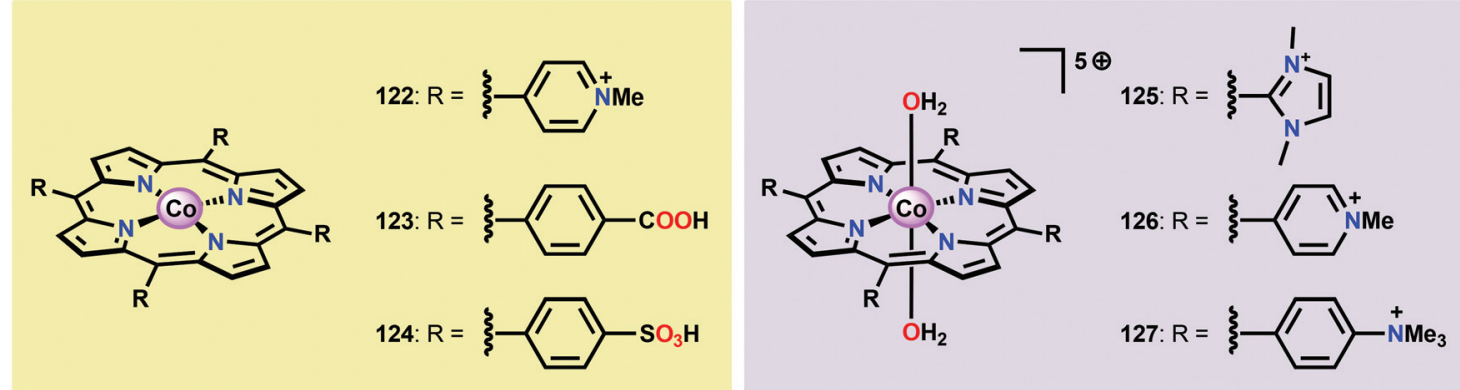

Fig. 45 Co porphyrins $122-127$ employed in $\mathrm{H}_{2} \mathrm{O}$ oxidation. 


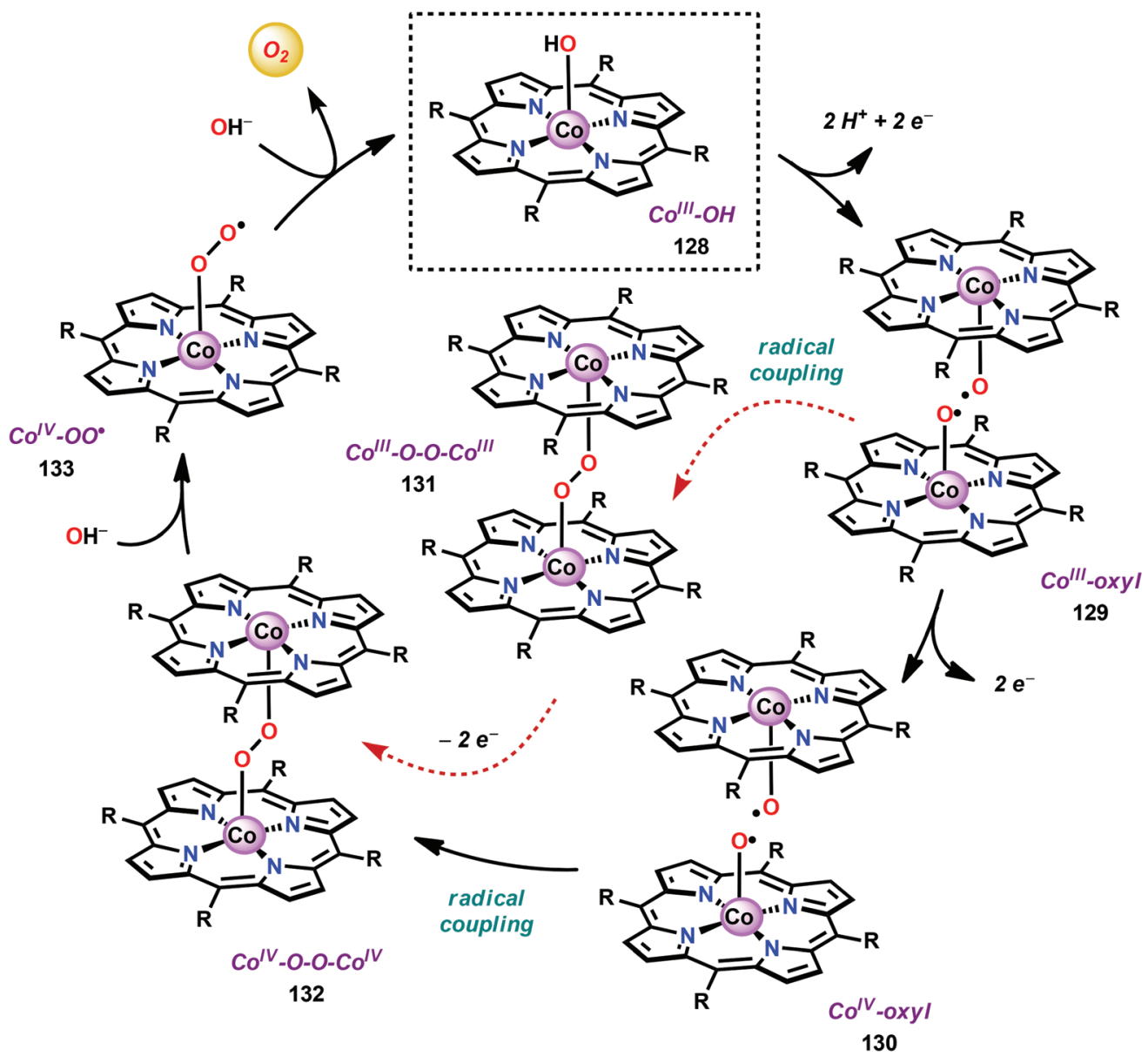

Scheme 8 Proposed pathways for O-O bond formation for Co porphyrins 122-124.

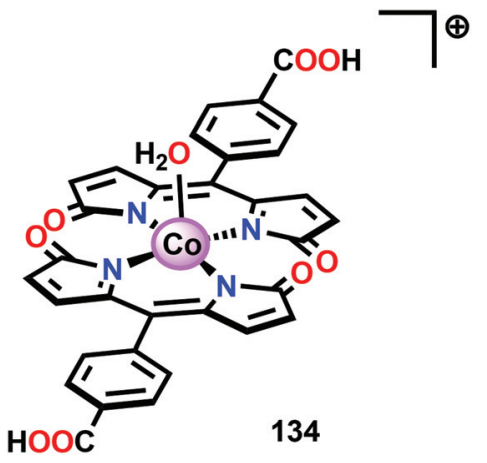

Fig. 46 Example of the observed decomposition product (134) of Co porphyrin 123.

dation. ${ }^{285}$ This observation suggests that the studied photosystem can undergo undesired side reactions with ${ }^{1} \mathrm{O}_{2}$, generated by the triplet state of either the Co-porphyrin or $\left[\mathrm{Ru}(\mathrm{bpy})_{3}\right]^{2+}$. With this in mind, Sakai and co-workers examined the resistance of Co porphyrins towards ${ }^{1} \mathrm{O}_{2} \cdot{ }^{286}$ By introducing fluorine substituents at the 2- and 6-positions of the porphyrin aryl units, to afford the fluorinated Co porphyrin 135 (Fig. 47), the

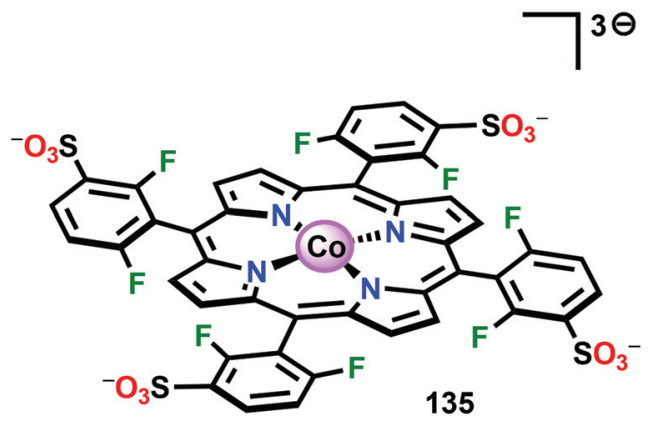

Fig. 47 Structure of fluorinated Co porphyrin 135.

attack of ${ }^{1} \mathrm{O}_{2}$ was effectively blocked. Comparing the fluorinated Co porphyrin complex $\mathbf{1 3 5}$ with the previously developed Co porphyrin 124 in light-sensitized $\mathrm{H}_{2} \mathrm{O}$ oxidation confirmed that the fluorinated catalyst was more resistant towards decomposition, and operates without loss of catalytic activity. In contrast to the earlier Co porphyrin WOCs 122-124, porphyrin 135 exhibited a first order dependence on the catalyst concentration. This disparity implies that the rate-determining step for catalyst 135 is $\mathrm{H}_{2} \mathrm{O}$ nucleophilic attack on a formal 
high-valent $\mathrm{Co}^{\mathrm{V}}$ species rather than oxyl coupling between two Co-oxyl units (Scheme 9). This study established the importance of resistance towards ${ }^{1} \mathrm{O}_{2}$ during light-driven $\mathrm{H}_{2} \mathrm{O}$ oxidation and that the rational design of ligands can deliver dramatically improved WOCs.

Groves and Wang have also synthesized a series of cationic Co-based porphyrin complexes (125-127) for $\mathrm{H}_{2} \mathrm{O}$ oxidation (Fig. 45). ${ }^{284}$ These porphyrin complexes were shown to mediate electrochemical $\mathrm{H}_{2} \mathrm{O}$ oxidation, with Co porphyrin 125, housing the electron-deficient ligand, being the most efficient catalyst. The key species for these WOCs was proposed to be a $\mathrm{Co}^{\mathrm{IV}}$-oxo species containing an oxidized radical porphyrin ligand $\left(\left[\left(\mathrm{L}^{*}\right) \mathrm{Co}^{\mathrm{IV}}\right.\right.$-oxo $\left.]\right)$, which can be considered as a formal $\mathrm{Co}^{\mathrm{V}}$-oxo species. Support of homogeneous $\mathrm{O}-\mathrm{O}$ bond formation at a single metal center was also given, thus resembling the mechanistic pathway for the fluorinated Co porphyrin 135 (Scheme 9).

Additional mononuclear Co-based WOCs that have been proposed to promote light-sensitized $\mathrm{H}_{2} \mathrm{O}$ oxidation through a homogeneous pathway are depicted in Fig. 48

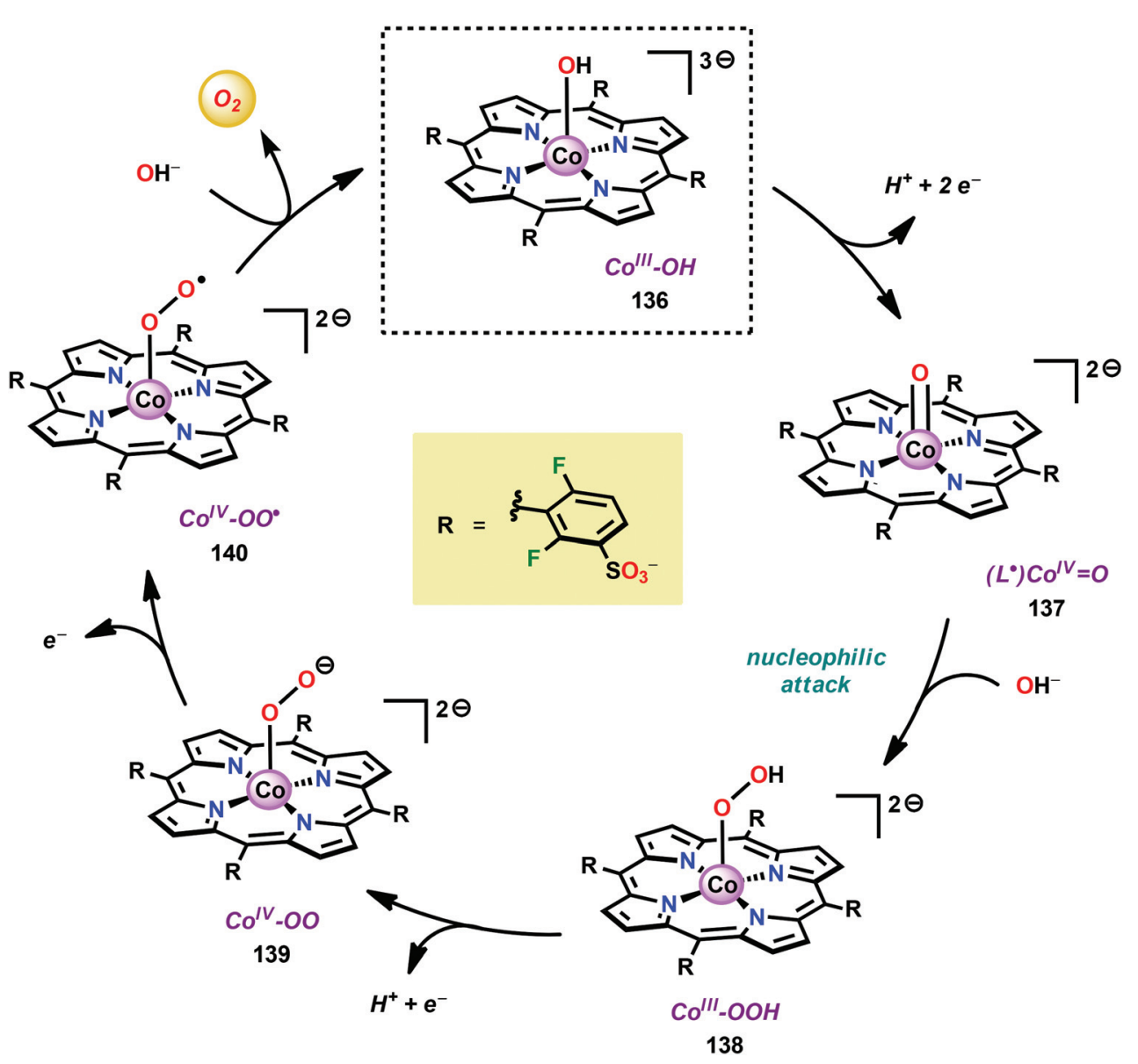

Scheme 9 Proposed mechanism for $\mathrm{H}_{2} \mathrm{O}$ oxidation catalyzed by the fluorinated Co porphyrin 135 .
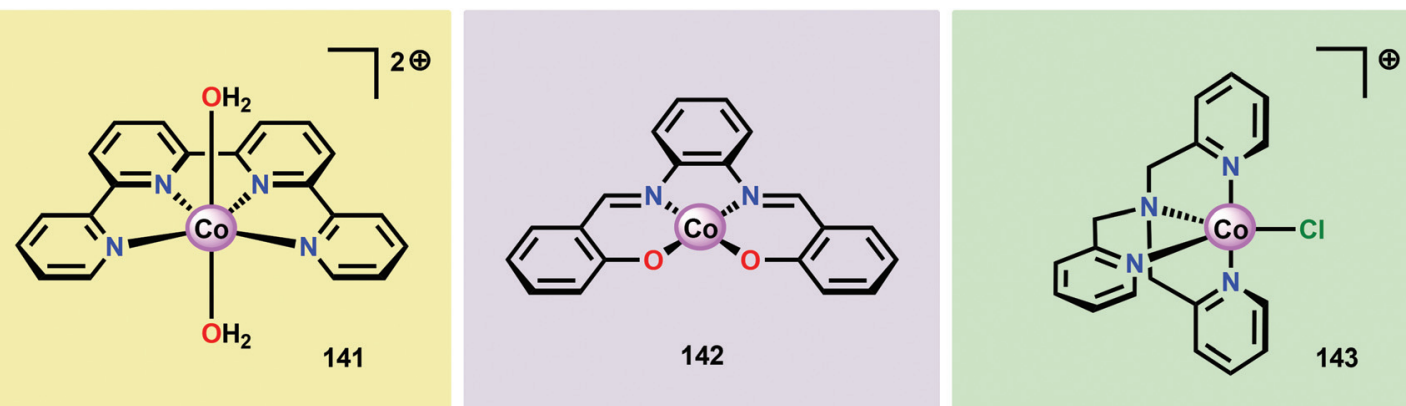

Fig. 48 Structures of Co complexes 141-143. 
and include the $\left[\mathrm{Co}^{\mathrm{II}}(\mathrm{qpy})\left(\mathrm{OH}_{2}\right)_{2}\right]^{2+}$ complex 141 (qpy = $2,2^{\prime}: 6^{\prime}, 2^{\prime \prime}: 6^{\prime \prime}, 2^{\prime \prime \prime}$-quaterpyridine), ${ }^{287}$ the $\mathrm{Co}^{\mathrm{II}}$ salophen complex $142{ }^{288}$ and related salophen complexes, ${ }^{289}$ and the $\mathrm{Co}^{\mathrm{II}}$ complex $[\mathrm{Co}(\mathrm{tpa}) \mathrm{Cl}]^{+} 143$ (tpa $=$ tris(2-pyridylmethyl)amine). ${ }^{290}$

Several Co-based complexes with organic ligand frameworks have been shown to act as precatalysts to heterogeneous Co nanoparticles (Fig. 49). ${ }^{291-293}$ Although the initial welldefined Co complexes are transformed into heterogeneous materials, the carbonaceous residues originating from the ligand frameworks act as modifiers or capping agents of the generated nanoparticles. This indicates that the ligands might affect the structure and efficiency of the nanoparticular catalysts and suggests a ligand dependent route to efficient and robust catalytic materials, opening an appealing avenue for future research.

\subsection{Dinuclear Co complexes as water oxidation catalysts}

A relatively unexplored area is the development of dinuclear Co-based WOCs. Although efforts have been devoted to preparing dinuclear Co-based WOCs, ${ }^{100,294}$ only a few examples of active dinuclear Co catalysts exist. Two of these Co catalysts (148 and 149, Fig. 50) are based on the bridging bispyridylpyrazolate (bpp) ligand. The bpp ligand was chosen since it was considered to provide an environment for the two Co centers which is stable towards hydrolysis and ligand decomposition. Indeed, as confirmed by electrochemical analysis, the two Cobpp complexes were able to evolve $\mathrm{O}_{2}$ under acidic conditions. ${ }^{295}$ Another example of an active dinuclear Co WOC is $\left[(\text { tpa }) \mathrm{Co}(\mu-\mathrm{OH})\left(\mu-\mathrm{O}_{2}\right) \mathrm{Co}(\mathrm{tpa})\right]^{3+}$ (150), which catalyzes lightinduced $\mathrm{H}_{2} \mathrm{O}$ oxidation using $\left[\mathrm{Ru}(\mathrm{bpy})_{3}\right]^{2+}$ as a photosensitizer and $\mathrm{Na}_{2} \mathrm{~S}_{2} \mathrm{O}_{8}$ as a sacrificial electron acceptor. ${ }^{296,297}$ The dinuclear $\left[(\text { tpa }) \mathrm{Co}(\mu-\mathrm{OH})\left(\mu-\mathrm{O}_{2}\right) \mathrm{Co}(\text { tpa })\right]^{3+}$ complex 150 was obtained by treating the previously developed mononuclear $[\mathrm{Co}(\mathrm{tpa}) \mathrm{Cl}]^{+}$ complex 143 with $\mathrm{LiClO}_{4}$ and $\mathrm{O}_{2}$, resulting in oxidation and formation of the $\mathrm{Co}_{2}^{\mathrm{III}, \mathrm{III}}$ complex 150. A pH of 8 was found to be optimal for the light-driven $\mathrm{O}_{2}$ evolution experiments, giving a TON of 58 with a TOF of $\sim 1.4 \mathrm{~s}^{-1}$. The molecular integrity of the dinuclear Co complex 150 during catalysis was assessed by DLS and suggested that no Co oxide colloids were produced. The proposed catalytic cycle for the oxidation of $\mathrm{H}_{2} \mathrm{O}$ by $\left[(\text { tpa }) \mathrm{Co}(\mu-\mathrm{OH})\left(\mu-\mathrm{O}_{2}\right) \mathrm{Co}(\text { tpa })\right]^{3+}$ complex 150 is depicted in Scheme 10 and revolves around the generation of a $(\mathrm{O}) \mathrm{Co}^{\mathrm{IV}-}$ $\mathrm{Co}^{\mathrm{IV}}(\mathrm{O})$ intermediate as the key species for intramolecular $\mathrm{O}-\mathrm{O}$ bond formation. ${ }^{296}$ Further mechanistic investigations will likely result in a fundamental understanding of the catalytic process and enable the design of more efficient dinuclear Cobased WOCs.
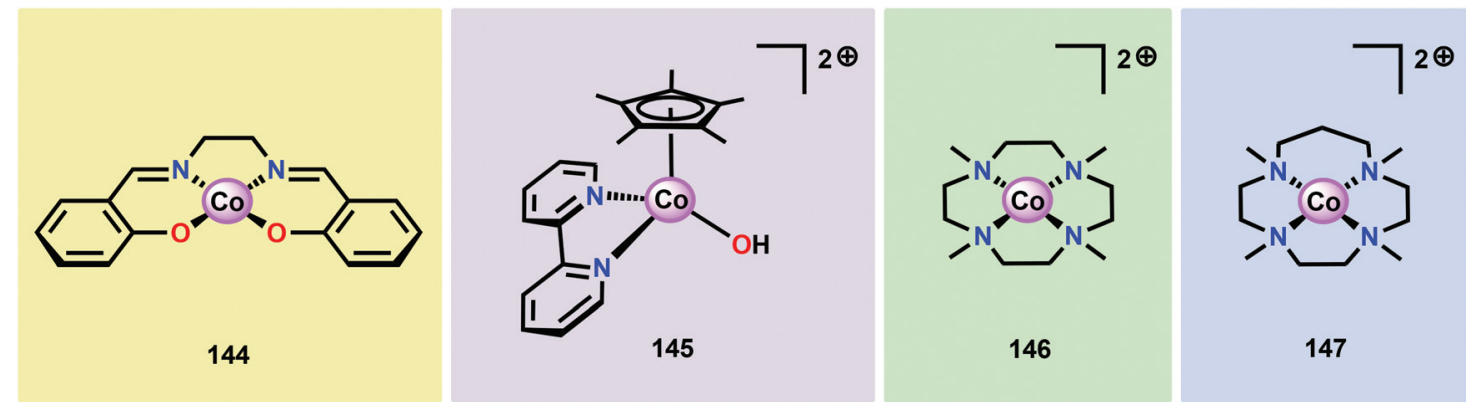

Fig. 49 Co-based complexes employed as precatalysts.
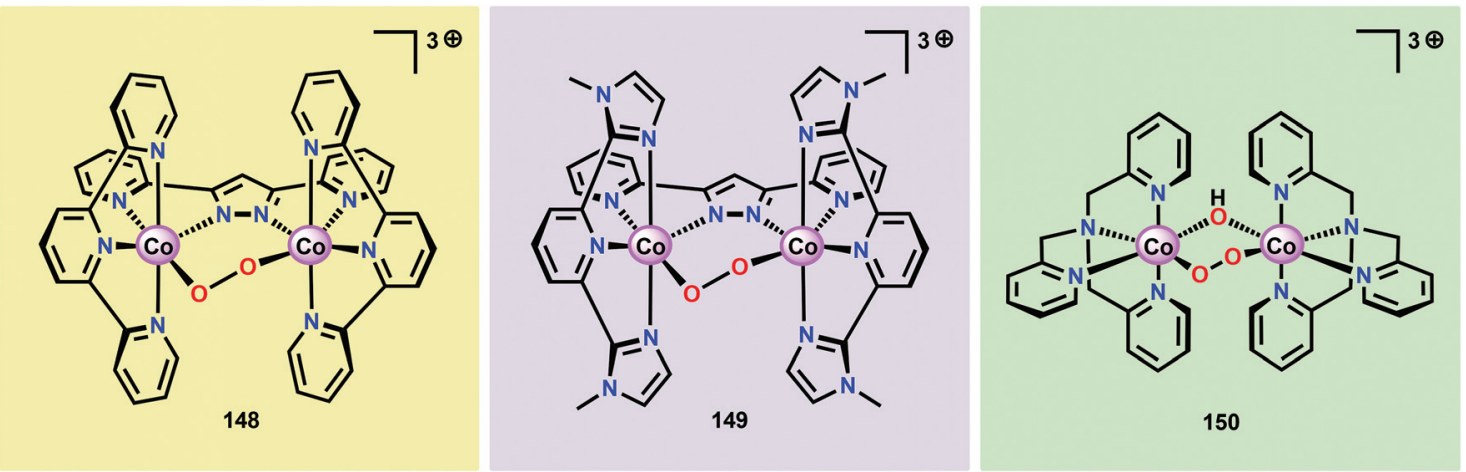

Fig. 50 Structures of dinuclear Co-based WOCs 148-150. 


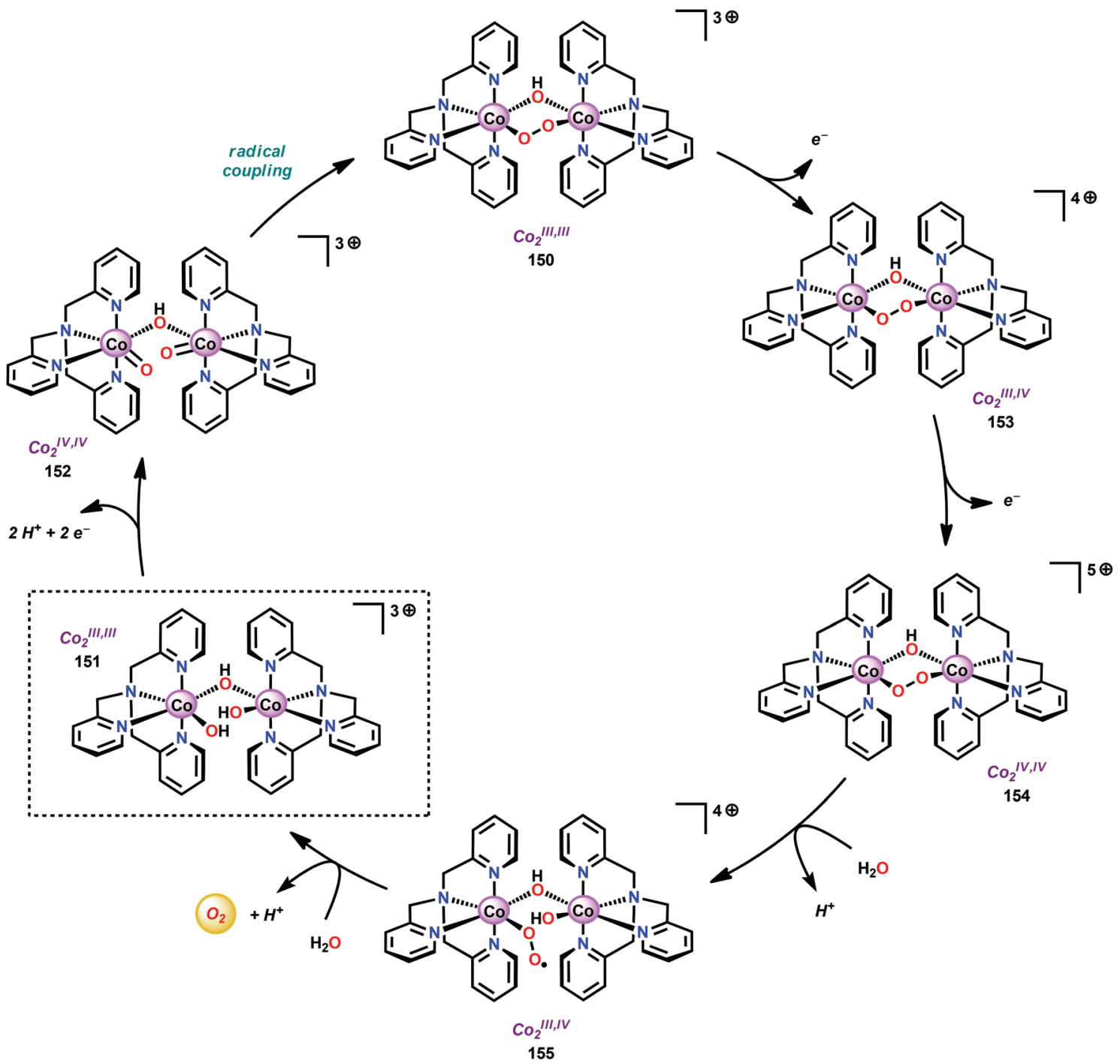

Scheme 10 Proposed mechanism for $\mathrm{H}_{2} \mathrm{O}$ oxidation catalyzed by the dinuclear $\left[(\mathrm{tpa}) \mathrm{Co}(\mu-\mathrm{OH})\left(\mu-\mathrm{O}_{2}\right) \mathrm{Co}(\mathrm{tpa})\right]^{3+} \operatorname{complex} 150$. tpa $=$ tris $(2-$ pyridylmethyl)amine.

\section{Homogeneous Cu-based systems for catalytic water oxidation}

Copper is a common catalyst for mediating aerobic oxidations using molecular oxygen as the terminal oxidant. ${ }^{298}$ However, only a handful of $\mathrm{Cu}$-based catalysts are known to be capable of promoting the opposite reaction $-\mathrm{H}_{2} \mathrm{O}$ oxidation. This can perhaps be explained by the metal's preference to carry out one-electron redox events rather than two-electron processes, which are at the core of $\mathrm{H}_{2} \mathrm{O}$ oxidation.

Early investigations on Cu-catalyzed $\mathrm{H}_{2} \mathrm{O}$ oxidation was conducted by Elizarova and co-workers. ${ }^{175}$ However, the first welldefined homogeneous Cu-based complex was reported by Mayer and co-workers in 2012. ${ }^{299}$ The authors examined the ability of the $\left[\mathrm{Cu}(\mathrm{bpy})(\mathrm{OH})_{2}\right]$ complex 156 (Fig. 51), a selfassembling $\mathrm{Cu}$ complex, to mediate electrochemical $\mathrm{H}_{2} \mathrm{O}$ oxidation. EPR measurements and control studies with $\mathrm{Cu}$ oxide

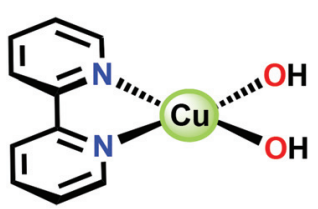

156

Fig. 51 Structure of the $\left[\mathrm{Cu}(\mathrm{bpy})(\mathrm{OH})_{2}\right]$ complex 156.

implied that the $\left[\mathrm{Cu}(\mathrm{bpy})(\mathrm{OH})_{2}\right]$ complex was homogeneous in nature. However, the stability of this $\mathrm{Cu}$ complex was severely hampered as it merely afforded a TON of $\sim 30$, highlighting that more robust catalysts need to be designed in order to access more efficient Cu-based WOCs.

Lin and co-workers recently studied the catalytic activity of 4,4'- and 6,6'-substituted bipyridine-based $\mathrm{Cu}$ complexes. The 
authors found that $\mathrm{Cu}$ complex 157, [Cu(bpyOH) $\left.(\mathrm{OH})_{2}\right]$, housing the 6,6'-dihydroxy-2,2'-bipyridine ligand provided an efficient WOC (Fig. 52). ${ }^{300}$ This ligand has previously been employed for other transformations, such as $\mathrm{CO}_{2}$ reduction ${ }^{301}$ and carbonylation reactions, ${ }^{302}$ where it was proposed to have a non-innocent role during the catalytic transformations. Lin and co-workers therefore utilized the 6,6'-dihydroxy-2,2'-bipyridine ligand, envisioning that the ligand could be employed as a redox-active entity to modify the reactivity of the metal center to enhance the catalytic activity. ${ }^{300}$

For $\mathrm{Cu}$ complex 157, $\mathrm{O}_{2}$ evolution was shown to occur in controlled potential electrolysis (CPE) with an overpotential of $\sim 640 \mathrm{mV}$, giving a TON of $\sim 400$. The 4,4'-dihydroxy-2,2'-bipyridine analogous $\mathrm{Cu}$ complex showed a significantly higher overpotential for $\mathrm{H}_{2} \mathrm{O}$ oxidation than $\mathrm{Cu}$ complex 156. Both experimental and computational studies suggested the involvement of the ligand framework in electron transfer and proton transfer events, thus enhancing the catalytic activity of the $\mathrm{Cu}$ based WOC. ${ }^{300}$ The chemistry of 6,6'-substituted 2,2'-bipyridine-based $\mathrm{Cu}$ complexes in $\mathrm{H}_{2} \mathrm{O}$ oxidation catalysis has also been investigated by the group of Papish. ${ }^{303}$

The group of Meyer has recently developed a self-assembling $\mathrm{Cu}$ tetrapeptide-based complex (158, Fig. 53). ${ }^{304} \mathrm{Cu}$ complex 158 contains a triglycylglycine ligand $\left(\mathrm{H}_{4} \operatorname{tgg}\right)$, which creates a suitable environment for the coordination of Cu. ${ }^{305,306}$ At pH 11, CPE showed that the catalytic current was maintained for $\sim 5 \mathrm{~h}$, resulting in a TON of $\sim 13$ based on the initial amount of $\mathrm{Cu}$ complex 158 in solution. Several lines of evidence supported a homogeneous mechanism: (1) no spectroscopic change of the electrolysis solution was observed, during CPE only minor changes in the peak current or wave

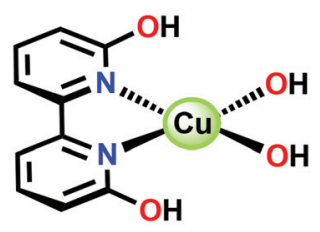

157

Fig. 52 Structure of the $\left[\mathrm{Cu}(\mathrm{bpyOH})(\mathrm{OH})_{2}\right]$ complex 157 shape were observed, (2) an electrode subjected to CPE at 1.32 $\mathrm{V}$ vs. NHE with $\mathrm{Cu}$ catalyst 158 resulted in no catalytic response when subjected to a fresh catalyst-free electrolyte solution, and (3) no precipitation or film generation was observed by SEM and XPS. ${ }^{304}$

The catalytic peak current for $\mathrm{H}_{2} \mathrm{O}$ oxidation was found to vary linearly with the concentration of $\mathrm{Cu}$ complex 158, suggesting a mechanism involving $\mathrm{O}-\mathrm{O}$ bond formation at a single-site $\mathrm{Cu}$ center. The proposed mechanism for oxidation of $\mathrm{H}_{2} \mathrm{O}$ by $\mathrm{Cu}$ complex 158 is shown in Scheme 11 and involves oxidation to produce a $\mathrm{Cu}^{\text {III }}$ species. A subsequent oxidation event furnishes a $\mathrm{Cu}^{\mathrm{IV}}$-oxo (or a $\mathrm{Cu}^{\mathrm{III}}$-oxyl) species, which is believed to be responsible for mediating $\mathrm{O}-\mathrm{O}$ bond formation. The produced hydroperoxide species, $\mathrm{Cu}^{\mathrm{II}}-\mathrm{OOH}$, is subsequently oxidized to $\mathrm{Cu}^{\mathrm{III}}-\mathrm{OO}^{\bullet}$ from which $\mathrm{O}_{2}$ is liberated, regenerating the $\mathrm{Cu}^{\mathrm{II}}$ catalyst 158 and closing the catalytic cycle. ${ }^{304,307}$ The two related $\mathrm{Cu}$ tetrapeptide complexes 159 and 160 (Fig. 53) have also recently been synthesized and studied in $\mathrm{H}_{2} \mathrm{O}$ oxidation. ${ }^{308}$

Llobet and co-workers recently prepared a family of $\mathrm{Cu}$ complexes (161-164) based on tetra-anionic tetradentate amidate ligands. ${ }^{309}$ The prepared $\mathrm{Cu}^{\mathrm{II}}$ complexes (Fig. 54) were found to be four-coordinate with a square planar geometry. Electrochemical measurements for the $\mathrm{Cu}^{\mathrm{II}}$ complexes revealed a significant electrocatalytic current corresponding to $\mathrm{H}_{2} \mathrm{O}$ oxidation together with two redox waves. The first quasi-reversible wave was assigned to a one-electron process, generating a $\mathrm{Cu}^{\mathrm{III}}$ species (eqn (6)). The subsequent $\mathrm{pH}$-dependent wave was proposed to be associated with a ligand-based oxidation, furnishing a formal aryl radical cation (eqn (7)):

$$
\begin{gathered}
{\left[(\mathrm{L}) \mathrm{Cu}^{\mathrm{II}}\right]^{2-} \rightarrow\left[(\mathrm{L}) \mathrm{Cu}^{\mathrm{III}}\right]^{-}+\mathrm{e}^{-}} \\
{\left[(\mathrm{L}) \mathrm{Cu}^{\mathrm{III}}\right]^{-}+\mathrm{OH}^{-} \rightarrow\left[\left(\mathrm{L}^{\cdot}\right) \mathrm{Cu}^{\mathrm{III}}(\mathrm{OH})\right]^{-}}
\end{gathered}
$$

The proposed mechanism for the oxidation of $\mathrm{H}_{2} \mathrm{O}$ by $\mathrm{Cu}$ complexes 161-164 involves initial formation of the $\left[\left(\mathrm{L}^{\circ}\right)\right.$ $\left.\mathrm{Cu}^{\mathrm{III}}(\mathrm{OH})\right]^{-}$species, which subsequently reacts with $\mathrm{OH}^{-}$to produce a $\mathrm{Cu}$-peroxo species, $\left[(\mathrm{L}) \mathrm{Cu}^{\mathrm{II}}(\mathrm{HOOH})\right]^{2-}$. This species undergoes a metal-based oxidation to form $\left[(\mathrm{L}) \mathrm{Cu}^{\mathrm{III}}(\mathrm{HOOH})\right]^{-}$. A final proton-coupled oxidation gives a $\left[(\mathrm{L}) \mathrm{Cu}^{\mathrm{III}}\left(\mathrm{HOO}^{\circ}\right)\right]^{-}$ species from which $\mathrm{O}_{2}$ is liberated, thus regenerating the start-

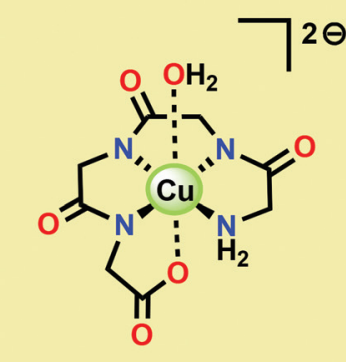

158

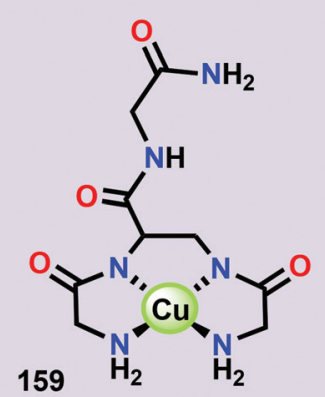

159

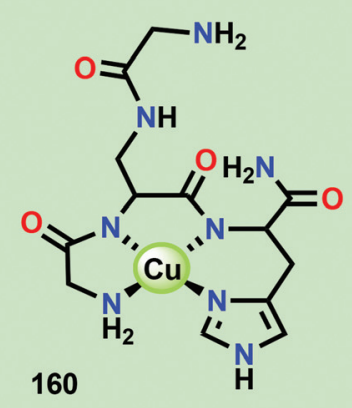

Fig. 53 Structures of peptide-based Cu complexes 158-160. 


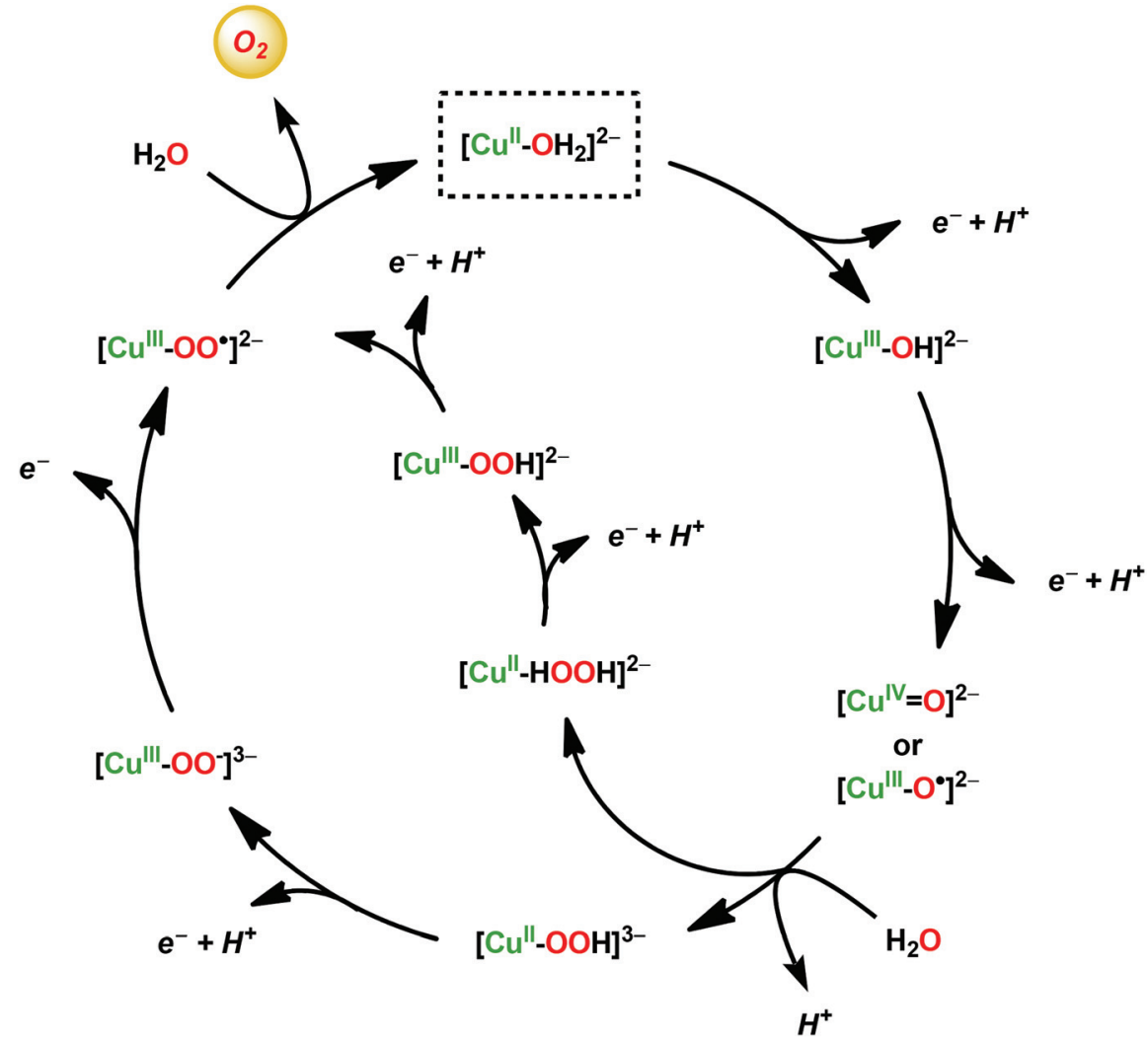

Scheme 11 Proposed mechanism for $\mathrm{H}_{2} \mathrm{O}$ oxidation catalyzed by $\mathrm{Cu}$ complex 158 .

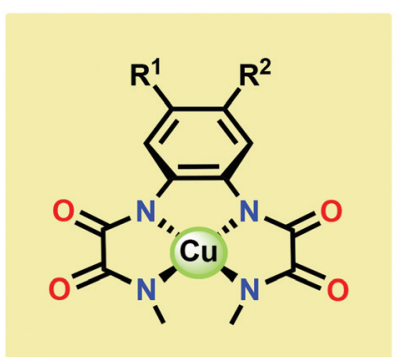

161: $\mathrm{R}^{1}=\mathrm{R}^{2}=\mathrm{H}$

162: $R^{1}=R^{2}=M e$

163: $R^{1}=H, R^{2}=O M e$

164: $\mathrm{R}^{1}=\mathrm{R}^{2}=\mathrm{OMe}$

Fig. $54 \mathrm{Cu}^{\prime \prime}$ complexes 161-164 based on tetradentate amidate ligands.

ing complex, $\left[(\mathrm{L}) \mathrm{Cu}^{\mathrm{II}}\right]^{2-} .309$ The use of tailored ligands which are able to donate electrons-being non-innocent-during the catalytic oxidation process can be essential for designing novel molecular WOCs where this cooperative effect can alleviate the metal center from being too highly oxidized during the catalytic process. ${ }^{310}$

The Cu-based WOCs described thus far require alkaline conditions in order to mediate electrochemical oxidation of $\mathrm{H}_{2} \mathrm{O}$. However, the dinuclear $\mathrm{Cu}_{2}^{\mathrm{II}, \mathrm{II}}$ complex 165 (Fig. 55) based on the 2,7-[bis(2-pyridylmethyl)aminomethyl]-1,8naphthyridine ligand (bpman) ligand has been reported to operate under neutral conditions. ${ }^{311}$ Reacting the dinucleating bpman ligand ${ }^{312,313}$ with 2 equivalents of $\mathrm{Cu}\left(\mathrm{CF}_{3} \mathrm{SO}_{3}\right)_{2}$ produced the $\mathrm{Cu}_{2}^{\mathrm{II}, \mathrm{II}}$ complex 165 in 71\% yield. Electrochemical

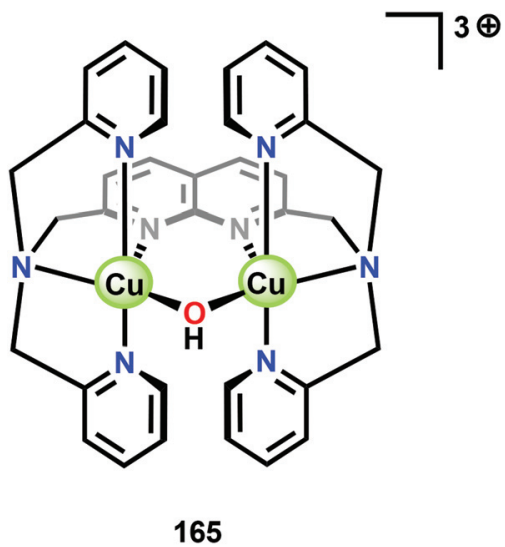

Fig. 55 Structure of the dinuclear $\mathrm{Cu}_{2}^{1, \text { II }}$ complex $\left[\mathrm{Cu}_{2}^{\text {II, II }}(\mathrm{bpman})\right.$ $(\mu-\mathrm{OH})]^{3+}(165)$. bpman $=2,7$-[bis (2-pyridylmethyl)aminomethyl $]-1,8-$ naphthyridine.

measurements of $\mathrm{Cu}$ complex 165 showed an onset potential for catalytic $\mathrm{H}_{2} \mathrm{O}$ oxidation starting at $\sim 1.6 \mathrm{~V} v s$. NHE. The catalytic activity of the dinuclear $\mathrm{Cu}$ complex 165 was assessed by $\mathrm{CPE}$ at $1.87 \mathrm{~V} v s$. NHE to give a TOF of $\sim 0.6 \mathrm{~s}^{-1}$ with a Faradaic efficiency of $\sim 98 \%$. Computational studies suggested that $\mathrm{O}-\mathrm{O}$ bond formation proceeded through a cooperative interaction between the two $\mathrm{Cu}^{\mathrm{III}}$ centers rather than by the formation of a $\mathrm{Cu}^{\mathrm{IV}}=\mathrm{O}$ unit in which a $\mathrm{Cu}^{\mathrm{III}}-\mathrm{O}(\mathrm{H})$ moiety couples with a 

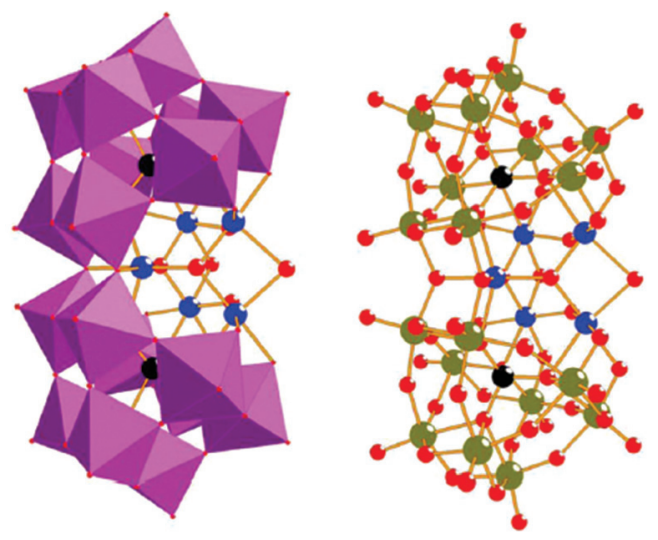

Fig. 56 Structure of the $\mathrm{Cu}$-containing POM $\left[\mathrm{Cu}_{5}(\mathrm{OH})_{4}\left(\mathrm{OH}_{2}\right)_{2}(\mathrm{~A}-\right.$ $\left.\left.\alpha-\mathrm{SiW}_{9} \mathrm{O}_{33}\right)_{2}\right]^{10-}(166)$. Color code: copper, turquoise; tungsten, green; silicon, black; oxygen, red. Reproduced from ref. 314 with permission from the Royal Society of Chemistry.

$\mu$-oxo unit. $^{311}$ The proposed $\mathrm{O}-\mathrm{O}$ bond forming step is different from the previously reported $\mathrm{Cu}$-based WOCs and could provide new routes for the activation of $\mathrm{H}_{2} \mathrm{O}$.

Ding and co-workers recently reported that the $\mathrm{Cu}$-containing POM $\left[\mathrm{Cu}_{5}(\mathrm{OH})_{4}\left(\mathrm{OH}_{2}\right)_{2}\left(\mathrm{~A}-\alpha-\mathrm{SiW}_{9} \mathrm{O}_{33}\right)_{2}\right]^{10-}(166)$ functions as a catalyst for visible light-driven water oxidation. ${ }^{314}$ The $\mathrm{Cu}$ substituted POM 166 (Fig. 56) was originally developed by Kortz and co-workers ${ }^{315}$ and consists of two $\mathrm{A}-\alpha-\left[\mathrm{SiW}_{9} \mathrm{O}_{34}\right]^{10-}$ Keggin moieties that are linked together through two $\mathrm{W}-\mathrm{O}-\mathrm{W}$ bonds and stabilized by a central $\left[\mathrm{Cu}_{5}(\mathrm{OH})_{4}\left(\mathrm{OH}_{2}\right)_{2}\right]^{6+}$ unit. Of the evaluated $\mathrm{Cu}$ POMs, POM 166 was the only complex that exhibited water oxidation activity. Using a system consisting of $\mathrm{Cu}$ POM 166, $\left[\mathrm{Ru}(\mathrm{bpy})_{3}\right]^{2+}$ as the photosensitizer and $\mathrm{S}_{2} \mathrm{O}_{8}{ }^{2-}$ as the sacrificial electron acceptor afforded a TON of 91 under optimized conditions. ${ }^{314}$ Several molecular Cu-based complexes have been reported to act as precursors to catalytically active heterogeneous materials, ${ }^{316-318}$ highlighting the importance of determining the true nature of the catalytic entity when studying Cu-based WOCs. For $\mathrm{Cu}$ POM 166, multiple experiments, including DLS, UV/vis spectroscopy and nanosecond laser flash photolysis experiments, suggest that $\mathrm{Cu}$ POM 166 is the dominant species under the studied catalytic conditions and that it operates through a homogeneous mechanism. $^{314}$

\section{Conclusions \& outlook}

Artificial photosynthesis is a competitive and rapidly expanding research field which offers routes to carbon-neutral and renewable fuels. Here, the development of robust catalysts for the oxidation of $\mathrm{H}_{2} \mathrm{O}$ is currently the bottleneck. Due to their low cost, catalysts based on earth-abundant first-row transition metals are highly attractive and have received considerable attention. This Perspective summarizes advances in the development of molecular WOCs composed of earth-abundant metals.
Although relatively few water oxidation catalysts based on first-row transition metals had been reported before the early 2000s, recent years have seen a dramatic increase in the number of such catalysts. However, a majority of these catalysts require two-electron oxo-transfer oxidants to drive $\mathrm{H}_{2} \mathrm{O}$ oxidation. Despite considerable progress in recent years, a limiting feature encountered with these first-row transition metal WOCs is their relative lability compared to catalysts based on second- and third-row transition metals, such as $\mathrm{Ru}$ and Ir. Due to the highly oxidizing conditions required to oxidize $\mathrm{H}_{2} \mathrm{O}$, the rational design of robust and efficient WOCs based on first-row transition metals still remains a crucial challenge.

A common topic in the discussion of molecular earth-abundant metal WOCs is the nature of the real catalytic entitytheir homogeneity. Their propensity to form metal oxide nanoparticles under the catalytic conditions is a feature that requires particular attention. The generation of heterogeneous materials from the initially well-defined metal complexes is facile and highly dependent on the reaction conditions where small changes can affect both the mechanistic pathway and the stability of the examined metal complex.

The structural knowledge gained from studying the $\mathrm{Mn}_{4} \mathrm{Ca}$ cluster in the OEC has inspired researchers to design small metal-based model clusters of various shapes and nuclearities. These seminal studies have afforded considerable insight for the rational synthesis of closely related artificial metal-based cubane mimics of the natural photosynthetic system. For a long time, Nature has been a great source of inspiration in the development of molecular photosynthetic mimics for solar energy to fuel conversion and will certainly continue to stimulate the design of molecular mimics based on earth-abundant metals.

\section{Acknowledgements}

Financial support from the Swedish Research Council (6212013-4872), the Knut and Alice Wallenberg Foundation and the Carl Trygger Foundation is gratefully acknowledged.

\section{References}

1 N. S. Lewis, ChemSusChem, 2009, 2, 383-386.

2 A. Cho, Science, 2010, 329, 786-787.

3 R. Schlögl, ChemSusChem, 2010, 3, 209-222.

4 L. Sun, L. Hammarström, B. Åkermark and S. Styring, Chem. Soc. Rev., 2001, 30, 36-49.

5 S. K. Ravi and S. C. Tan, Energy Environ. Sci., 2015, 8, 2551-2573.

6 J. Marshall, Nature, 2014, 510, 22-24.

7 H. Inoue, T. Shimada, Y. Kou, Y. Nabetani, D. Masui, S. Takagi and H. Tachibana, ChemSusChem, 2011, 4, 173179.

8 D. W. Lawlor, Photosynthesis, Springer-Verlag, New York, 2001. 
9 R. Croce and H. van Amerongen, Nat. Chem. Biol., 2014, 10, 492-501.

10 J. Yano and V. Yachandra, Chem. Rev., 2014, 114, 41754205.

11 M. Mahdi Najafpour, A. N. Moghaddam, S. I. Allakhverdiev and Govindjee, Biochim. Biophys. Acta, 2012, 1817, 1110-1121.

12 M. Suga, F. Akita, K. Hirata, G. Ueno, H. Murakami, Y. Nakajima, T. Shimizu, K. Yamashita, M. Yamamoto, H. Ago and J.-R. Shen, Nature, 2015, 517, 99-103.

13 Y. Umena, K. Kawakami, J.-R. Shen and N. Kamiya, Nature, 2011, 473, 55-60.

14 K. N. Ferreira, T. M. Iverson, K. Maghlaoui, J. Barber and S. Iwata, Science, 2004, 303, 1831-1838.

15 A. Zouni, H.-T. Witt, J. Kern, P. Fromme, N. Krauss, W. Saenger and P. Orth, Nature, 2001, 409, 739-743.

16 J.-R. Shen, Annu. Rev. Plant Biol., 2015, 66, 23-48.

17 N. Cox, M. Retegan, F. Neese, D. A. Pantazis, A. Boussac and W. Lubitz, Science, 2014, 345, 804-808.

18 H. Nilsson, F. Rappaport, A. Boussac and J. Messinger, Nat. Commun., 2014, 5, 4305.

19 P. E. M. Siegbahn, Biochim. Biophys. Acta, 2013, 1827, 1003-1019.

20 N. Cox, D. A. Pantazis, F. Neese and W. Lubitz, Acc. Chem. Res., 2013, 46, 1588-1596.

21 H. Bao and R. L. Burnap, Proc. Natl. Acad. Sci. U. S. A., 2015, 112, E6139-E6147.

22 P. E. M. Siegbahn, Acc. Chem. Res., 2009, 42, 1871-1880.

23 For recent reviews on water splitting, see for example: (a) H. Dau, C. Limberg, T. Reier, M. Risch, S. Roggan and P. Strasser, ChemCatChem, 2010, 2, 724-761; (b) M. G. Walter, E. L. Warren, J. R. McKone, S. W. Boettcher, Q. Mi, E. A. Santori and N. S. Lewis, Chem. Rev., 2010, 110, 6446-6473; (c) K. S. Joya, Y. F. Joya, K. Ocakoglu and R. van de Krol, Angew. Chem., Int. Ed., 2013, 52, 10426-10437; (d) D. J. Wasylenko, R. D. Palmer and C. P. Berlinguette, Chem. Commun., 2013, 49, 218-227; (e) J. R. McKone, N. S. Lewis and H. B. Gray, Chem. Mater., 2014, 26, 407-414; $(f)$ T. Takata, C. Pan and K. Domen, ChemElectroChem, 2016, 3, 31-37; (g) M. G. Mali, H. Yoon, H. Kim, B. Joshi, S. S. Al-Deyab and S. S. Yoon, ChemPhysChem, 2015, 16, 3450-3457.

24 For recent reviews on $\mathrm{Ru}$ - and Ir-based water oxidation catalysts, see: (a) M. D. Kärkäs, O. Verho, E. V. Johnston and B. Åkermark, Chem. Rev., 2014, 114, 11863-12001; (b) J. D. Blakemore, R. H. Crabtree and G. W. Brudvig, Chem. Rev., 2015, 115, 12974-13005; (c) M. Okamura and S. Masaoka, Chem. - Asian J., 2015, 10, 306-315; (d) L. Duan, L. Wang, F. Li, F. Li and L. Sun, Acc. Chem. Res., 2015, 48, 2084-2096; (e) Q. Zeng, F. W. Lewis, L. M. Harwood and F. Hartl, Coord. Chem. Rev., 2015, 304-305, 88-101; $(f)$ M. D. Kärkäs and B. Åkermark, Chem. Rec., 2016, 16, 940-963.

25 T. Privalov, B. Åkermark and L. Sun, Chem. - Eur. J., 2011, 17, 8313-8317.
26 X. Sala, S. Maji, R. Bofill, J. García-Antón, L. Escriche and A. Llobet, Acc. Chem. Res., 2014, 47, 504-516.

27 M. G. Mavros, T. Tsuchimochi, T. Kowalczyk, A. McIsaac, L.-P. Wang and T. Van Voorhis, Inorg. Chem., 2014, 53, 6386-6397.

28 T. Kikuchi and K. Tanaka, Eur. J. Inorg. Chem., 2014, 607618.

29 P. Du and R. Eisenberg, Energy Environ. Sci., 2012, 5, 6012-6021.

30 A. Singh and L. Spiccia, Coord. Chem. Rev., 2013, 257, 2607-2622.

31 S. Fukuzumi, D. Hong and Y. Yamada, J. Phys. Chem. Lett., 2013, 4, 3458-3467.

32 A. R. Parent and K. Sakai, ChemSusChem, 2014, 7, 20702080.

33 E. Wadsworth, F. R. Duke and C. A. Goetz, Anal. Chem., 1957, 29, 1824-1825.

34 For selected examples of water oxidation catalysts evaluated with $\mathrm{Ce}^{\mathrm{IV}}$, see: (a) D. J. Wasylenko, C. Ganesamoorthy, B. D. Koivisto, M. A. Henderson and C. P. Berlinguette, Inorg. Chem., 2010, 49, 2202-2209; (b) A. Savini, G. Bellachioma, G. Ciancaleoni, C. Zuccaccia, D. Zuccaccia and A. Macchioni, Chem. Commun., 2010, 46, 9218-9219; (c) J. D. Blakemore, N. D. Schley, D. Balcells, J. F. Hull, G. W. Olack, C. D. Incarvito, O. Eisenstein, G. W. Brudvig and R. H. Crabtree, J. Am. Chem. Soc., 2010, 132, 16017-16029; (d) M. D. Kärkäs, E. V. Johnston, E. A. Karlsson, B.-L. Lee, T. Åkermark, M. Shariatgorji, L. Ilag, Ö. Hansson, J.-E. Bäckvall and B. Åkermark, Chem. - Eur. J., 2011, 17, 7953-7959; (e) L. Duan, F. Bozoglian, S. Mandal, B. Stewart, T. Privalov, A. Llobet and L. Sun, Nat. Chem., 2012, 4, 418-423; ( $f$ ) J. J. Concepcion, D. K. Zhong, D. J. Szalda, J. T. Muckerman and E. Fujita, Chem. Commun., 2015, 51, 4105-4108; (g) I. López, S. Maji, J. Benet-Buchholz and A. Llobet, Inorg. Chem., 2015, 54, 658-666; (h) L. Tong, R. Zong, R. Zhou, N. Kaveevivitchai, G. Zhang and R. P. Thummel, Faraday Discuss., 2015, 185, 87-104.

35 For an example of using Oxone ${ }^{\circledR}$ to evaluate water oxidation activity, see: J. Limburg, J. S. Vrettos, L. M. LiableSands, A. L. Rheingold, R. H. Crabtree and G. W. Brudvig, Science, 1999, 283, 1524-1527.

36 For an example of using $\mathrm{NaIO}_{4}$ to evaluate water oxidation activity, see: A. R. Parent, T. P. Brewster, W. De Wolf, R. H. Crabtree and G. W. Brudvig, Inorg. Chem., 2012, 51, 6147-6152.

37 A. Robert and B. Meunier, New J. Chem., 1988, 12, 885896.

38 L. K. Weavers, I. Hua and M. R. Hoffmann, Water Environ. Res., 1997, 69, 1112-1119.

39 For a recent review discussing the advantages of different chemical oxidants used in the evaluation of water oxidation catalysts, see: A. R. Parent, R. H. Crabtree and G. W. Brudvig, Chem. Soc. Rev., 2013, 42, 22472252. 
40 A. Ikeda-Ohno, S. Tsushima, C. Hennig, T. Yaita and G. Bernhard, Dalton Trans., 2012, 41, 7190-7192.

41 T. J. Demars, M. K. Bera, S. Seifert, M. R. Antonio and R. J. Ellis, Angew. Chem., Int. Ed., 2015, 54, 7534-7538.

42 For examples of water oxidation catalysts evaluated with $\left[\mathrm{Ru}(\mathrm{bpy})_{3}\right]^{3+}$, see: (a) L. Duan, Y. Xu, P. Zhang, M. Wang and L. Sun, Inorg. Chem., 2010, 49, 209-215; (b) M. D. Kärkäs, T. Åkermark, E. V. Johnston, S. R. Karim, T. M. Laine, B.-L. Lee, T. Åkermark, T. Privalov and B. Åkermark, Angew. Chem., Int. Ed., 2012, 51, 1158911593; (c) M. D. Kärkäs, T. Åkermark, H. Chen, J. Sun and B. Åkermark, Angew. Chem., Int. Ed., 2013, 52, 4189-4193; (d) T. M. Laine, M. D. Kärkäs, R.-Z. Liao, T. Åkermark, B.-L. Lee, E. A. Karlsson, P. E. M. Siegbahn and B. Åkermark, Chem. Commun., 2015, 51, 1862-1865; (e) T. M. Laine, M. D. Kärkäs, R.-Z. Liao, P. E. M. Siegbahn and B. Åkermark, Chem. - Eur. J., 2015, 21, 10039-10048; (f) W. Rabten, M. D. Kärkäs, T. Åkermark, H. Chen, R.-Z. Liao, F. Tinnis, J. Sun, P. E. M. Siegbahn, P. G. Andersson and B. Åkermark, Inorg. Chem., 2015, 54, 4611-4620; $(g)$ W. Rabten, T. Åkermark, M. D. Kärkäs, H. Chen, J. Sun, P. G. Andersson and B. Åkermark, Dalton Trans., 2016, 45, 3272-3276; (h) M. D. Kärkäs, R.-Z. Liao, T. M. Laine, T. Åkermark, S. Ghanem, P. E. M. Siegbahn and B. Åkermark, Catal. Sci. Technol., 2016, 6, 1306-1319.

43 S. Campagna, F. Puntoriero, F. Nastasi, G. Bergamini and V. Balzani, Top. Curr. Chem., 2007, 280, 117-214.

44 D. M. Roundhill, in Photochemistry and Photophysics of Metal Complexes, ed. J. P. Fackler, Jr., Springer-Verlag, New York, 1st edn, 1994, vol. 5, pp. 165-215.

45 F. Teplý, Collect. Czech. Chem. Commun., 2011, 76, 859917.

46 B. C. Gau, H. Chen, Y. Zhang and M. L. Gross, Anal. Chem., 2010, 82, 7821-7827.

47 For a recent review on molecular chromophore-catalyst assemblies, see: D. L. Ashford, M. K. Gish, A. K. Vannucci, M. K. Brennaman, J. L. Templeton, J. M. Papanikolas and T. J. Meyer, Chem. Rev., 2015, 115, 13006-13049.

48 A. J. Bard and L. R. Faulkner, Electrochemical Methods: Fundamentals and Applications, John Wiley \& Sons Inc., New York, 2nd edn, 2001.

49 For a recent review on electrochemical water oxidation with earth-abundant transition-metal catalysts, see: J. R. Galán-Mascarós, ChemElectroChem, 2015, 2, 37-50.

50 For discussions on distinguishing homogeneous from heterogeneous catalysis, see: (a) J. A. Widegren and R. G. Finke, J. Mol. Catal. A: Chem., 2003, 198, 317-341; (b) R. H. Crabtree, Chem. Rev., 2012, 112, 1536-1554; (c) V. Artero and M. Fontecave, Chem. Soc. Rev., 2013, 42, 2338-2356; (d) S. Fukuzumi and D. Hong, Eur. J. Inorg. Chem., 2014, 645-659; (e) X. Wu, F. Li, B. Zhang and L. Sun, J. Photochem. Photobiol., C, 2015, 25, 71-89; (f) S. Fukuzumi, J. Jung, Y. Yamada, T. Kojima and W. Nam, Chem. - Asian J., 2016, 11, 1138-1150.

51 (a) A. Asraf, H. A. Younus, M. Yusubov and F. Verpoort, Catal. Sci. Technol., 2015, 5, 4901-4925; (b) C. Lu, J. Du,
X.-J. Su, M.-T. Zhang, X. Xu, T. J. Meyer and Z. Chen, ACS Catal., 2016, 6, 77-83.

52 For a review on Mn-based complexes with relevance to Photosystem II, see: S. Mukhopadhyay, S. K. Mandal, S. Bhaduri and W. H. Armstrong, Chem. Rev., 2004, 104, 3981-4026.

53 Y. Naruta, M.-a. Sasayama and T. Sasaki, Angew. Chem., Int. Ed., 1994, 33, 1839-1841.

54 Y. Shimazaki, T. Nagano, H. Takesue, B.-H. Ye, F. Tani and Y. Naruta, Angew. Chem., Int. Ed., 2004, 43, 98-100.

55 J. Chen, P. Wagner, L. Tong, G. G. Wallace, D. L. Officer and G. F. Swiegers, Angew. Chem., Int. Ed., 2012, 51, 19071910.

56 J. Limburg, J. S. Vrettos, H. Chen, J. C. de Paula, R. H. Crabtree and G. W. Brudvig, J. Am. Chem. Soc., 2001, 123, 423-430.

57 C. W. Cady, K. E. Shinopoulos, R. H. Crabtree and G. W. Brudvig, Dalton Trans., 2010, 39, 3985-3989.

58 H. Chen, R. Tagore, G. Olack, J. S. Vrettos, T.-C. Weng, J. Penner-Hahn, R. H. Crabtree and G. W. Brudvig, Inorg. Chem., 2007, 46, 34-43.

59 R. Tagore, R. H. Crabtree and G. W. Brudvig, Inorg. Chem., 2008, 47, 1815-1823.

60 R. Tagore, H. Chen, H. Zhang, R. H. Crabtree and G. W. Brudvig, Inorg. Chim. Acta, 2007, 360, 2983-2989.

61 Several reports suggest that the dimeric Mn complex 5 is not able to produce $\mathrm{O}_{2}$ without the help of an oxygendonating oxidant, see: (a) M. Yagi and K. Narita, J. Am. Chem. Soc., 2004, 126, 8084-8085; (b) C. Baffert, S. Romain, A. Richardot, J.-C. Leprêtre, B. Lefebvre, A. Deronzier and M.-N. Collomb, J. Am. Chem. Soc., 2005, 127, 13694-13704; (c) P. Kurz, G. Berggren, M. F. Anderlund and S. Styring, Dalton Trans., 2007, 42584261.

62 K. Narita, T. Kuwabara, K. Sone, K.-i. Shimizu and M. Yagi, J. Phys. Chem. B, 2006, 110, 23107-23114.

63 H. Yamazaki, T. Nagata and M. Yagi, Photochem. Photobiol. Sci., 2009, 8, 204-209.

64 M. Yagi, M. Toda, S. Yamada and H. Yamazaki, Chem. Commun., 2010, 46, 8594-8596.

65 M. Hirahara, H. Yamazaki, S. Yamada, K. Matsubara, K. Saito, T. Yui and M. Yagi, Catal. Sci. Technol., 2013, 3, 1776-1781.

66 M. Yagi, K. Narita, S. Maruyama, K. Sone, T. Kuwabara and K.-i. Shimizu, Biochim. Biophys. Acta, Bioenerg., 2007, 1767, 660-665.

67 G. Li, E. M. Sproviero, R. C. Snoeberger, III., N. Iguchi, J. D. Blakemore, R. H. Crabtree, G. W. Brudvig and V. S. Batista, Energy Environ. Sci., 2009, 2, 230-238.

68 G. Li, E. M. Sproviero, W. R. McNamara, R. C. Snoeberger, III., R. H. Crabtree, G. W. Brudvig and V. S. Batista, J. Phys. Chem. B, 2010, 114, 14214-14222.

69 B. Nepal and S. Das, Angew. Chem., Int. Ed., 2013, 52, 7224-7227.

70 R. E. Hansen and S. Das, Energy Environ. Sci., 2014, 7, 317-322. 
71 J. Limburg, G. W. Brudvig and R. H. Crabtree, J. Am. Chem. Soc., 1997, 119, 2761-2762.

72 H. Chen, R. Tagore, S. Das, C. Incarvito, J. W. Faller, R. H. Crabtree and G. W. Brudvig, Inorg. Chem., 2005, 44, 7661-7670.

73 M. M. Najafpour and V. McKee, Catal. Commun., 2010, 11, 1032-1035.

74 H. Yamazaki, S. Igarashi, T. Nagata and M. Yagi, Inorg. Chem., 2012, 51, 1530-1539.

75 H. Yamazaki, T. Ueno, K. Aiso, M. Hirahara, T. Aoki, T. Nagata, S. Igarashi and M. Yagi, Polyhedron, 2013, 52, 455-460.

76 M. Hatakeyama, H. Nakata, M. Wakabayashi, S. Yokojima and S. Nakamura, J. Phys. Chem. A, 2012, 116, 7089-7097.

77 I. Rivalta, K. R. Yang, G. W. Brudvig and V. S. Batista, ACS Catal., 2015, 5, 2384-2390.

78 S. Khan, K. R. Yang, M. Z. Ertem, V. S. Batista and G. W. Brudvig, ACS Catal., 2015, 5, 7104-7113.

79 H. Chen, J. W. Faller, R. H. Crabtree and G. W. Brudvig, J. Am. Chem. Soc., 2004, 126, 7345-7349.

80 H. Chen, M.-N. Collomb, C. Duboc, G. Blondin, E. Rivière, J. W. Faller, R. H. Crabtree and G. W. Brudvig, Inorg. Chem., 2005, 44, 9567-9573.

81 Y. Gao, R. H. Crabtree and G. W. Brudvig, Inorg. Chem., 2012, 51, 4043-4050.

82 M. M. Najafpour, A. N. Moghaddam, H. Dau and I. Zaharieva, J. Am. Chem. Soc., 2014, 136, 7245-7248.

83 C. Baffert, M.-N. Collomb, A. Deronzier, S. KjærgaardKnudsen, J.-M. Latour, K. H. Lund, C. J. McKenzie, M. Mortensen, L. P. Nielsen and N. Thorup, Dalton Trans., 2003, 1765-1772.

84 A. K. Poulsen, A. Rompel and C. J. McKenzie, Angew. Chem., Int. Ed., 2005, 44, 6916-6920.

85 R. K. Seidler-Egdal, A. Nielsen, A. D. Bond, M. J. Bjerrum and C. J. McKenzie, Dalton Trans., 2011, 40, 3849-3858.

86 W. M. C. Sameera, C. J. McKenzie and J. E. McGrady, Dalton Trans., 2011, 40, 3859-3870.

87 L. Sun, H. Berglund, R. Davydov, T. Norrby, L. Hammarström, P. Korall, A. Börje, C. Philouze, K. Berg, A. Tran, M. Andersson, G. Stenhagen, J. Mårtensson, M. Almgren, S. Styring and B. Åkermark, J. Am. Chem. Soc., 1997, 119, 6996-7004.

88 L. Hammarström, L. Sun, B. Åkermark and S. Styring, Spectrochim. Acta, Part A, 2001, 57, 2145-2160.

89 A. Johansson, M. Abrahamsson, A. Magnuson, P. Huang, J. Mårtensson, S. Styring, L. Hammarström, L. Sun and B. Åkermark, Inorg. Chem., 2003, 42, 7502-7511.

90 A. Magnuson, M. Anderlund, O. Johansson, P. Lindblad, R. Lomoth, T. Polivka, S. Ott, K. Stensjö, S. Styring, V. Sundström and L. Hammarström, Acc. Chem. Res., 2009, 42, 1899-1909.

91 C. Herrero, A. Quaranta, S. Protti, W. Leibl, A. W. Rutherford, R. Fallahpour, M.-F. Charlot and A. Aukauloo, Chem. - Asian J., 2011, 6, 1335-1339.

92 C. E. Castillo, S. Romain, M. Retegan, J.-C. Leprêtre, J. Chauvin, C. Duboc, J. Fortage, A. Deronzier and M.-N. Collomb, Eur. J. Inorg. Chem., 2012, 5485-5499.
93 P. Huang, A. Magnuson, R. Lomoth, M. Abrahamsson, M. Tamm, L. Sun, B. van Rotterdam, J. Park, L. Hammarström, B. Åkermark and S. Styring, J. Inorg. Biochem., 2002, 91, 159-172.

94 G. Berggren, A. Thapper, P. Huang, P. Kurz, L. Eriksson, S. Styring and M. F. Anderlund, Dalton Trans., 2009, 10044-10054.

95 G. Berggren, A. Thapper, P. Huang, L. Eriksson, S. Styring and M. F. Anderlund, Inorg. Chem., 2011, 50, 3425-3430.

96 K. Beckmann, H. Uchtenhagen, G. Berggren, M. F. Anderlund, A. Thapper, J. Messinger, S. Styring and P. Kurz, Energy Environ. Sci., 2008, 1, 668-676.

97 P. Kurz, Dalton Trans., 2009, 6103-6108.

98 H.-M. Berends, A.-M. Manke, C. Näther, F. Tuczek and P. Kurz, Dalton Trans., 2012, 41, 6215-6224.

99 E. A. Karlsson, B.-L. Lee, T. Åkermark, E. V. Johnston, M. D. Kärkäs, J. Sun, Ö. Hansson, J.-E. Bäckvall and B. Åkermark, Angew. Chem., Int. Ed., 2011, 50, 1171511718.

100 B.-L. Lee, M. D. Kärkäs, E. V. Johnston, A. K. Inge, L.-H. Tran, Y. Xu, Ö. Hansson, X. Zou and B. Åkermark, Eur. J. Inorg. Chem., 2010, 5462-5470.

101 T. Norrby, A. Börje, B. Åkermark, L. Hammarström, J. Alsins, K. Lashgari, R. Norrestam, J. Mårtensson and G. Stenhagen, Inorg. Chem., 1997, 36, 5850-5858.

102 E. A. Karlsson, B.-L. Lee, R.-Z. Liao, T. Åkermark, M. D. Kärkäs, V. Saavedra Becerril, P. E. M. Siegbahn, X. Zou, M. Abrahamsson and B. Åkermark, ChemPlusChem, 2014, 79, 936-950.

103 W. A. A. Arafa, M. D. Kärkäs, B.-L. Lee, T. Åkermark, R.-Z. Liao, H.-M. Berends, J. Messinger, P. E. M. Siegbahn and B. Åkermark, Phys. Chem. Chem. Phys., 2014, 16, 11950-11964.

104 R.-Z. Liao, M. D. Kärkäs, B.-L. Lee, B. Åkermark and P. E. M. Siegbahn, Inorg. Chem., 2015, 54, 342-351.

105 I. Garcia-Bosch, A. Company, C. W. Cady, S. Styring, W. R. Browne, X. Ribas and M. Costas, Angew. Chem., Int. Ed., 2011, 50, 5648-5653.

106 D. E. Lansky, B. Mandimutsira, B. Ramdhanie, M. Clausén, J. Penner-Hahn, S. A. Zvyagin, J. Telser, J. Krzystek, R. Zhan, Z. Ou, K. M. Kadish, L. Zakharov, A. L. Rheingold and D. P. Goldberg, Inorg. Chem., 2005, 44, 4485-4498.

107 W. J. Song, M. S. Seo, S. DeBeer George, T. Ohta, R. Song, M.-J. Kang, T. Tosha, T. Kitagawa, E. I. Solomon and W. Nam, J. Am. Chem. Soc., 2007, 129, 1268-1277.

108 X. Wu, X. Yang, Y.-M. Lee, W. Nam and L. Sun, Chem. Commun., 2015, 51, 4013-4016.

109 G. Yin, Acc. Chem. Res., 2013, 46, 483-492.

110 F. M. Ashmawy, C. A. McAuliffe, R. V. Parish and J. Tames, J. Chem. Soc., Dalton Trans., 1985, 1391-1397.

111 M. K. Awad and A. B. Anderson, J. Am. Chem. Soc., 1989, 111, 802-806.

112 A. Garcia-Deibe, A. Sousa, M. R. Bermejo, P. P. Mac Rory, C. A. McAuliffe, R. G. Pritchard and M. Helliwell, J. Chem. Soc., Chem. Commun., 1991, 728-729. 
113 N. Aurangzeb, C. E. Hulme, C. A. McAuliffe, R. G. Pritchard, M. Watkinson, M. R. Bermejo, A. GarciaDeibe, M. Rey, J. Sanmartin and A. Sousa, J. Chem. Soc., Chem. Commun., 1994, 1153-1155.

114 M. Watkinson, A. Whiting and C. A. McAuliffe, J. Chem. Soc., Chem. Commun., 1994, 2141-2142.

115 M. M. Najafpour and D. M. Boghaei, Transition Met. Chem., 2009, 34, 367-372.

116 G. González-Riopedre, M. I. Fernández-García, A. M. González-Noya, M. Á. Vázquez-Fernández, M. R. Bermejo and M. Maneiro, Phys. Chem. Chem. Phys., 2011, 13, 18069-18077.

117 S. Kal, L. Ayensu-Mensah and P. H. Dinolfo, Inorg. Chim. Acta, 2014, 423, 201-206.

118 Y. Gao, J. Liu, M. Wang, Y. Na, B. Åkermark and L. Sun, Tetrahedron, 2007, 63, 1987-1994.

119 T. Privalov, L. Sun, B. Åkermark, J. Liu, Y. Gao and M. Wang, Inorg. Chem., 2007, 46, 7075-7086.

120 Y. Gao, T. Åkermark, J. Liu, L. Sun and B. Åkermark, J. Am. Chem. Soc., 2009, 131, 8726-8727.

121 W.-T. Lee, S. B. Muñoz, III., D. A. Dickie and J. M. Smith, Angew. Chem., Int. Ed., 2014, 53, 9856-9859.

122 W.-T. Lee, S. Xu, D. A. Dickie and J. M. Smith, Eur. J. Inorg. Chem., 2013, 3867-3873.

123 J. M. Rowland, M. Olmstead and P. K. Mascharak, Inorg. Chem., 2001, 40, 2810-2817.

124 M. Lubben, A. Meetsma, E. C. Wilkinson, B. Feringa and L. Que, Jr., Angew. Chem., Int. Ed. Engl., 1995, 34, 15121514.

125 R. A. Geiger, D. F. Leto, S. Chattopadhyay, P. Dorlet, E. Anxolabéhère-Mallart and T. A. Jackson, Inorg. Chem., 2011, 50, 10190-10203.

126 R. T. Jonas and T. D. P. Stack, J. Am. Chem. Soc., 1997, 119, 8566-8567.

127 M. E. de Vries, R. M. La Crois, G. Roelfes, H. Kooijman, A. L. Spek, R. Hage and B. L. Feringa, Chem. Commun., 1997, 1549-1550.

128 K. J. Young, M. K. Takase and G. W. Brudvig, Inorg. Chem., 2013, 52, 7615-7622.

129 T. J. Collins and S. W. Gordon-Wylie, J. Am. Chem. Soc., 1989, 111, 4511-4513.

130 G. Berggren, F. B. Kaynak, M. F. Anderlund, L. Eriksson and B. Åkermark, Acta Crystallogr., Sect. E: Struct. Rep. Online, 2007, 63, m2672-m2673.

131 T. Taguchi, R. Gupta, B. Lassalle-Kaiser, D. W. Boyce, V. K. Yachandra, W. B. Tolman, J. Yano, M. P. Hendrich and A. S. Borovik, J. Am. Chem. Soc., 2012, 134, 1996-1999.

132 C. R. Goldsmith, A. P. Cole and T. D. P. Stack, J. Am. Chem. Soc., 2005, 127, 9904-9912.

133 For a review on molecular Mn mimics, see: C. S. Mullins and V. L. Pecoraro, Coord. Chem. Rev., 2008, 252, 416-443.

134 S. Wang, K. Folting, W. E. Streib, E. A. Schmitt, J. K. McCusker, D. N. Hendrickson and G. Christou, Angew. Chem., Int. Ed. Engl., 1991, 30, 305-306.

135 C. Gedye, C. Harding, V. McKee, J. Nelson and J. Patterson, J. Chem. Soc., Chem. Commun., 1992, 392-394.
136 S. Wang, H.-L. Tsai, K. S. Hagen, D. N. Hendrickson and G. Christou, J. Am. Chem. Soc., 1994, 116, 8376-8377.

137 C. R. Hamilton, R. A. Baglia, A. D. Gordon and M. J. Zdilla, J. Am. Chem. Soc., 2011, 133, 4208-4211.

138 S. Vaddypally, S. K. Kondaveeti and M. J. Zdilla, Inorg. Chem., 2012, 51, 3950-3952.

139 C. R. Hamilton, M. R. Gau, R. A. Baglia, S. F. McWilliams and M. J. Zdilla, J. Am. Chem. Soc., 2014, 136, 17974-17986.

140 C. Zhang, C. Chen, H. Dong, J.-R. Shen, H. Dau and J. Zhao, Science, 2015, 348, 690-693.

141 A. Mishra, W. Wernsdorfer, K. A. Abboud and G. Christou, Chem. Commun., 2005, 54-56.

142 S. Mukherjee, J. A. Stull, J. Yano, T. C. Stamatatos, K. Pringouri, T. A. Stich, K. A. Abboud, R. D. Britt, V. K. Yachandra and G. Christou, Proc. Natl. Acad. Sci. U. S. A., 2012, 109, 2257-2262.

143 S. Nayak, H. P. Nayek, S. Dehnen, A. K. Powell and J. Reedijk, Dalton Trans., 2011, 40, 2699-2702.

144 W. F. Ruettinger, C. Campana and G. C. Dismukes, J. Am. Chem. Soc., 1997, 119, 6670-6671.

145 T. G. Carrell, S. Cohen and G. C. Dismukes, J. Mol. Catal. A: Chem., 2002, 187, 3-15.

146 W. F. Ruettinger, D. M. Ho and G. C. Dismukes, Inorg. Chem., 1999, 38, 1036-1037.

147 T. G. Carrell, E. Bourles, M. Lin and G. C. Dismukes, Inorg. Chem., 2003, 42, 2849-2858.

148 R. Brimblecombe, A. M. Bond, G. C. Dismukes, G. F. Swiegers and L. Spiccia, Phys. Chem. Chem. Phys., 2009, 11, 6441-6449.

149 J.-Z. Wu, E. Sellitto, G. P. A. Yap, J. Sheats and G. C. Dismukes, Inorg. Chem., 2004, 43, 5795-5797.

150 W. Ruettinger, M. Yagi, K. Wolf, S. Bernasek and G. C. Dismukes, J. Am. Chem. Soc., 2000, 122, 1035310357.

151 M. Yagi, K. V. Wolf, P. J. Baesjou, S. L. Bernasek and G. Charles Dismukes, Angew. Chem., Int. Ed., 2001, 40, 2925-2928.

152 J.-Z. Wu, F. De Angelis, T. G. Carrell, G. P. A. Yap, J. Sheats, R. Car and G. C. Dismukes, Inorg. Chem., 2006, 45, 189-195.

153 R.-Z. Liao and P. E. M. Siegbahn, J. Photochem. Photobiol., $B, 2015,152,162-172$.

154 A. J. Seen, J. Mol. Catal. A: Chem., 2001, 177, 105-112.

155 R. Brimblecombe, G. F. Swiegers, G. C. Dismukes and L. Spiccia, Angew. Chem., Int. Ed., 2008, 47, 7335-7338.

156 R. Brimblecombe, D. R. J. Kolling, A. M. Bond, G. C. Dismukes, G. F. Swiegers and L. Spiccia, Inorg. Chem., 2009, 48, 7269-7279.

157 R. Brimblecombe, A. M. Bond, G. C. Dismukes, G. F. Swiegers and L. Spiccia, Phys. Chem. Chem. Phys., 2009, 11, 6441-6449.

158 R. Brimblecombe, A. Koo, G. C. Dismukes, G. F. Swiegers and L. Spiccia, ChemSusChem, 2010, 3, 1146-1150.

159 R. Brimblecombe, J. Chen, P. Wagner, T. Buchhorn, G. C. Dismukes, L. Spiccia and G. F. Swiegers, J. Mol. Catal. A: Chem., 2011, 338, 1-6. 
160 R. Brimblecombe, A. Koo, G. C. Dismukes, G. F. Swiegers and L. Spiccia, J. Am. Chem. Soc., 2010, 132, 2892-2894.

161 R. K. Hocking, R. Brimblecombe, L.-Y. Chang, A. Singh, M. H. Cheah, C. Glover, W. H. Casey and L. Spiccia, Nat. Chem., 2011, 3, 461-466.

162 D. F. Ghanotakis, G. T. Babcock and C. F. Yocum, FEBS Lett., 1984, 167, 127-130.

163 G. W. Brudvig, Philos. Trans. R. Soc. London, Ser. B, 2008, 363, 1211-1219.

164 J. Dasgupta, R. T. van Willigen and G. C. Dismukes, Phys. Chem. Chem. Phys., 2004, 6, 4793-4802.

165 J. S. Kanady, E. Y. Tsui, M. W. Day and T. Agapie, Science, 2011, 333, 733-736.

166 E. Y. Tsui, R. Tran, J. Yano and T. Agapie, Nat. Chem., 2013, 5, 293-299.

167 E. Y. Tsui and T. Agapie, Proc. Natl. Acad. Sci. U. S. A., 2013, 110, 10084-10088.

168 E. Y. Tsui, J. S. Kanady and T. Agapie, Inorg. Chem., 2013, 52, 13833-13848.

169 J. S. Kanady, J. L. Mendoza-Cortes, E. Y. Tsui, R. J. Nielsen, W. A. Goddard, III and T. Agapie, J. Am. Chem. Soc., 2013, 135, 1073-1082.

170 J. S. Kanady, P.-H. Lin, K. M. Carsch, R. J. Nielsen, M. K. Takase, W. A. Goddard, III and T. Agapie, J. Am. Chem. Soc., 2014, 136, 14373-14376.

171 P.-H. Lin, M. K. Takase and T. Agapie, Inorg. Chem., 2015, 54, 59-64.

172 S. Suseno, C. C. L. McCrory, R. Tran, S. Gul, J. Yano and T. Agapie, Chem. - Eur. J., 2015, 21, 13420-13430.

173 Y. Yan, J. S. Lee and D. A. Ruddy, Inorg. Chem., 2015, 54, 4550-4555.

174 For recent reviews on Fe catalysis, see: (a) M. Darwish and M. Wills, Catal. Sci. Technol., 2012, 2, 243-255; (b) D. Bézier, J.-B. Sortais and C. Darcel, Adv. Synth. Catal., 2013, 355, 19-33; (c) K. Riener, S. Haslinger, A. Raba, M. P. Högerl, M. Cokoja, W. A. Herrmann and F. E. Kühn, Chem. Rev., 2014, 114, 5215-5272; (d) I. Bauer and H.-J. Knölker, Chem. Rev., 2015, 115, 3170-3387.

175 G. L. Elizarova, L. G. Matvienko, N. V. Lozhkina, V. N. Parmonand and K. I. Zamaraev, React. Kinet. Catal. Lett., 1981, 16, 191-194.

176 W. C. Ellis, N. D. McDaniel, S. Bernhard and T. J. Collins, J. Am. Chem. Soc., 2010, 132, 10990-10991.

177 A. D. Ryabov and T. J. Collins, Adv. Inorg. Chem., 2009, 61, 471-521.

178 A. Ghosh, F. T. de Oliveira, T. Yano, T. Nishioka, E. S. Beach, I. Kinoshita, E. Münck, A. D. Ryabov, C. P. Horwitz and T. J. Collins, J. Am. Chem. Soc., 2005, 127, 2505-2513.

179 L. L. Tang, W. A. Gunderson, A. C. Weitz, M. P. Hendrich, A. D. Ryabov and T. J. Collins, J. Am. Chem. Soc., 2015, 137, 9704-9715.

180 A. Chanda, X. Shan, M. Chakrabarti, W. C. Ellis, D. L. Popescu, F. T. de Oliveira, D. Wang, L. Que, Jr., T. J. Collins, E. Münck and E. L. Bominaar, Inorg. Chem., 2008, 47, 3669-3678.
181 F. T. de Oliveira, A. Chanda, D. Banerjee, X. Shan, S. Mondal, L. Que Jr., E. L. Bominaar, E. Münck and T. J. Collins, Science, 2007, 315, 835-838.

182 E. L. Demeter, S. L. Hilburg, N. R. Washburn, T. J. Collins and J. R. Kitchin, J. Am. Chem. Soc., 2014, 136, 5603-5606.

183 C. Panda, J. Debgupta, D. Díaz Díaz, K. K. Singh, S. S. Gupta and B. B. Dhar, J. Am. Chem. Soc., 2014, 136, 12273-12282.

184 M. Ghosh, K. K. Singh, C. Panda, A. Weitz, M. P. Hendrich, T. J. Collins, B. B. Dhar and S. S. Gupta, J. Am. Chem. Soc., 2014, 136, 9524-9527.

185 M. Z. Ertem, L. Gagliardi and C. J. Cramer, Chem. Sci., 2012, 3, 1293-1299.

186 K. K. Singh, M. k. Tiwari, M. Ghosh, C. Panda, A. Weitz, M. P. Hendrich, B. B. Dhar, K. Vanka and S. S. Gupta, Inorg. Chem., 2015, 54, 1535-1542.

187 K. K. Singh, M. k. Tiwari, B. B. Dhar, K. Vanka and S. S. Gupta, Inorg. Chem., 2015, 54, 6112-6121.

188 Q. Ren, Y. Guo, M. R. Mills, A. D. Ryabov and T. J. Collins, Eur. J. Inorg. Chem., 2015, 1445-1452.

189 R.-Z. Liao, X.-C. Li and P. E. M. Siegbahn, Eur. J. Inorg. Chem., 2014, 728-741.

190 J. Lloret-Fillol, Z. Codolà, I. Garcia-Bosch, L. Gómez, J. J. Pla and M. Costas, Nat. Chem., 2011, 3, 807-813.

191 Z. Codolà, I. Garcia-Bosch, F. Acuña-Parés, I. Prat, J. M. Luis, M. Costas and J. Lloret-Fillol, Chem. - Eur. J., 2013, 19, 8042-8047.

192 F. Acuña-Parés, Z. Codolà, M. Costas, J. M. Luis and J. Lloret-Fillol, Chem. - Eur. J., 2014, 20, 5696-5707.

193 Z. Codolà, L. Gómez, S. T. Kleespies, L. Que, Jr., M. Costas and J. Lloret-Fillol, Nat. Commun., 2015, 6, 5865.

194 E. E. Kasapbasi and M.-H. Whangbo, Inorg. Chem., 2012, 51, 10850-10855.

195 F. Acuña-Parés, M. Costas, J. M. Luis and J. Lloret-Fillol, Inorg. Chem., 2014, 53, 5474-5485.

196 B. Zhang, F. Li, F. Yu, H. Cui, X. Zhou, H. Li, Y. Wang and L. Sun, Chem. - Asian J., 2014, 9, 1515-1518.

197 Y. Liu, R. Xiang, X. Du, Y. Ding and B. Ma, Chem. Commun., 2014, 50, 12779-12782.

198 W.-P. To, T. W.-S. Chow, C.-W. Tse, X. Guan, J.-S. Huang and C.-M. Che, Chem. Sci., 2015, 6, 5891-5903.

199 B. M. Klepser and B. M. Bartlett, J. Am. Chem. Soc., 2014, 136, 1694-1697.

200 M. K. Coggins, M.-T. Zhang, A. K. Vannucci, C. J. Dares and T. J. Meyer, J. Am. Chem. Soc., 2014, 136, 5531-5534.

201 Y. Hitomi, K. Arakawa, T. Funabiki and M. Kodera, Angew. Chem., Int. Ed., 2012, 51, 3448-3452.

202 W. A. Hoffert, M. T. Mock, A. M. Appel and J. Y. Yang, Eur. J. Inorg. Chem., 2013, 3846-3857.

203 K. G. Kottrup and D. G. H. Hetterscheid, Chem. Commun., 2016, 52, 2643-2646.

204 G. Chen, L. Chen, S.-M. Ng, W.-L. Man and T.-C. Lau, Angew. Chem., Int. Ed., 2013, 52, 1789-1791.

205 D. Hong, S. Mandal, Y. Yamada, Y.-M. Lee, W. Nam, A. Llobet and S. Fukuzumi, Inorg. Chem., 2013, 52, 95229531. 
206 M. M. Najafpour, A. N. Moghaddam, D. J. Sedigh and M. Hołyńska, Catal. Sci. Technol., 2014, 4, 30-33.

207 A. R. Parent, T. Nakazono, S. Lin, S. Utsunomiya and K. Sakai, Dalton Trans., 2014, 43, 12501-12513.

208 L. D. Wickramasinghe, R. Zhou, R. Zong, P. Vo, K. J. Gagnon and R. P. Thummel, J. Am. Chem. Soc., 2015, 137, 13260-13263.

209 L. Tong, R. Zong and R. P. Thummel, J. Am. Chem. Soc., 2014, 136, 4881-4884.

210 M. Okamura, M. Kondo, R. Kuga, Y. Kurashige, T. Yanai, S. Hayami, V. K. K. Praneeth, M. Yoshida, K. Yoneda, S. Kawata and S. Masaoka, Nature, 2016, 530, 465-468.

211 M. Anbar and I. Pecht, J. Am. Chem. Soc., 1967, 89, 25532556.

212 V. Y. Shafirovich and V. V. Strelets, Nouv. J. Chim., 1978, 2, 199-201.

213 V. Y. Shafirovich, N. K. Khannanov and V. V. Strelets, Nouv. J. Chim., 1980, 4, 81-84.

214 B. S. Brunschwig, M. H. Chou, C. Creutz, P. Ghosh and N. Sutin, J. Am. Chem. Soc., 1983, 105, 4832-4833.

215 M. W. Kanan and D. G. Nocera, Science, 2008, 321, 10721075.

216 Y. Surendranath, M. Dincă and D. G. Nocera, J. Am. Chem. Soc., 2009, 131, 2615-2620.

217 D. A. Lutterman, Y. Surendranath and D. G. Nocera, J. Am. Chem. Soc., 2009, 131, 3838-3839.

218 A. J. Esswein, Y. Surendranath, S. Y. Reece and D. G. Nocera, Energy Environ. Sci., 2011, 4, 499-504.

219 M. Risch, V. Khare, I. Zaharieva, L. Gerencser, P. Chernev and H. Dau, J. Am. Chem. Soc., 2009, 131, 6936-6937.

220 M. W. Kanan, J. Yano, Y. Surendranath, M. Dincă, V. K. Yachandra and D. G. Nocera, J. Am. Chem. Soc., 2010, 132, 13692-13701.

221 J. G. McAlpin, Y. Surendranath, M. Dincă, T. A. Stitch, S. A. Stoian, W. H. Casey, D. G. Nocera and R. D. Britt, J. Am. Chem. Soc., 2010, 132, 6882-6883.

222 Y. Surendranath, M. W. Kanan and D. G. Nocera, J. Am. Chem. Soc., 2010, 132, 16501-16509.

223 J. B. Gerken, J. G. McAlpin, J. Y. C. Chen, M. L. Rigsby, W. H. Casey, R. D. Britt and S. S. Stahl, J. Am. Chem. Soc., 2011, 133, 14431-14442.

224 P. Du, O. Kokhan, K. W. Chapman, P. J. Chupas and D. M. Tiede, J. Am. Chem. Soc., 2012, 134, 11096-11099.

225 D. G. Nocera, Acc. Chem. Res., 2012, 45, 767-776.

226 X. L. Hu, S. Piccinin, A. Laio and S. Fabris, ACS Nano, 2012, 6, 10497-10504.

227 C. L. Farrow, D. K. Bediako, Y. Surendranath, D. G. Nocera and S. J. L. Billinge, J. Am. Chem. Soc., 2013, 135, 64036406.

228 D. K. Bediako, C. Costentin, E. C. Jones, D. G. Nocera and J.-M. Savéant, J. Am. Chem. Soc., 2013, 135, 10492-10502.

229 A. M. Ullman and D. G. Nocera, J. Am. Chem. Soc., 2013, 135, 15053-15061.

230 Q. Yin, J. M. Tan, C. Besson, Y. V. Geletii, D. G. Musaev, A. E. Kuznetsov, Z. Luo, K. I. Hardcastle and C. L. Hill, Science, 2010, 328, 342-345.
231 Z. Huang, Z. Luo, Y. V. Geletii, J. W. Vickers, Q. Yin, D. Wu, Y. Hou, Y. Ding, J. Song, D. G. Musaev, C. L. Hill and T. Lian, J. Am. Chem. Soc., 2011, 133, 2068-2071.

232 For reviews on polyoxometalates (POMs) as water oxidation catalysts, see: (a) H. Lv, Y. V. Geletii, C. Zhao, J. W. Vickers, G. Zhu, Z. Luo, J. Song, T. Lian, D. G. Musaev and C. L. Hill, Chem. Soc. Rev., 2012, 41, 7572-7589; (b) J. M. Sumliner, H. Lv, J. Fielden, Y. V. Geletii and C. L. Hill, Eur. J. Inorg. Chem., 2014, 635644.

233 For a recent review on polyoxometalate (POM) catalyzed reactions, see: S.-S. Wang and G.-Y. Yang, Chem. Rev., 2015, 115, 4893-4962.

234 For examples of Ni-based POMs as water oxidation catalysts, see: (a) G. Zhu, E. N. Glass, C. Zhao, H. Lv, J. W. Vickers, Y. V. Geletii, D. G. Musaev, J. Song and C. L. Hill, Dalton Trans., 2012, 41, 13043-13049; (b) X.-B. Han, Y.-G. Li, Z.-M. Zhang, H.-Q. Tan, Y. Lu and E.-B. Wang, J. Am. Chem. Soc., 2015, 137, 5486-5493.

235 Y. V. Geletii, B. Botar, P. Kögerler, D. A. Hillesheim, D. G. Musaev and C. L. Hill, Angew. Chem., Int. Ed., 2008, 47, 3896-3899.

236 A. Sartorel, M. Carraro, G. Scorrano, R. D. Zorzi, S. Geremia, N. D. McDaniel, S. Bernhard and M. Bonchio, J. Am. Chem. Soc., 2008, 130, 5006-5007.

237 D. Lieb, A. Zahl, E. F. Wilson, C. Streb, L. C. Nye, K. Meyer and I. Ivanović-Burmazović, Inorg. Chem., 2011, 50, 90539058.

238 C. A. Ohlin, S. J. Harley, J. G. McAlpin, R. K. Hocking, B. Q. Mercado, R. L. Johnson, E. M. Villa, M. K. Fidler, M. M. Olmstead, L. Spiccia, R. D. Britt and W. H. Casey, Chem. - Eur. J., 2011, 17, 4408-4417.

239 M. Natali, S. Berardi, A. Sartorel, M. Bonchio, S. Campagna and F. Scandola, Chem. Commun., 2012, 48, 8808-8810.

240 J. Wu, L. Liao, W. Yan, Y. Xue, Y. Sun, X. Yan, Y. Chen and Y. Xie, ChemSusChem, 2012, 5, 1207-1212.

241 H. Lv, J. Song, Y. V. Geletii, J. W. Vickers, J. M. Sumliner, D. G. Musaev, P. Kögerler, P. F. Zhuk, J. Bacsa, G. Zhu and C. L. Hill, J. Am. Chem. Soc., 2014, 136, 92689271.

242 X.-B. Han, Z.-M. Zhang, T. Zhang, Y.-G. Li, W. Lin, W. You, Z.-M. Su and E.-B. Wang, J. Am. Chem. Soc., 2014, 136, 5359-5366.

243 J. J. Stracke and R. G. Finke, J. Am. Chem. Soc., 2011, 133, 14872-14875.

244 J. J. Stracke and R. G. Finke, ACS Catal., 2013, 3, 12091219.

245 J. W. Vickers, H. Lv, J. M. Sumliner, G. Zhu, Z. Luo, D. G. Musaev, Y. V. Geletii and C. L. Hill, J. Am. Chem. Soc., 2013, 135, 14110-14118.

246 S. Goberna-Ferrón, J. Soriano-López, J. R. Galán-Mascarós and M. Nyman, Eur. J. Inorg. Chem., 2015, 2833-2840.

247 S. Goberna-Ferrón, L. Vigara, J. Soriano-López and J. R. Galán-Mascarós, Inorg. Chem., 2012, 51, 1170711715. 
248 J. Soriano-López, S. Goberna-Ferrón, L. Vigara, J. J. Carbó, J. M. Poblet and J. R. Galán-Mascarós, Inorg. Chem., 2013, 52, 4753-4755.

249 F. Song, Y. Ding, B. Ma, C. Wang, Q. Wang, X. Du, S. Fu and J. Song, Energy Environ. Sci., 2013, 6, 1170-1184.

250 J. Wei, Y. Feng, P. Zhou, Y. Liu, J. Xu, R. Xiang, Y. Ding, C. Zhao, L. Fan and C. Hu, ChemSusChem, 2015, 8, 26302634.

251 C. Zhang, X. Lin, Z. Zhang, L.-S. Long, C. Wang and W. Lin, Chem. Commun., 2014, 50, 11591-11594.

252 D. Guo, S. Teng, Z. Liu, W. You and L. Zhang, J. Cluster Sci., 2013, 24, 549-558.

253 S. Tanaka, M. Annaka and K. Sakai, Chem. Commun., 2012, 48, 1653-1655.

254 F. Evangelisti, P.-E. Car, O. Blacque and G. R. Patzke, Catal. Sci. Technol., 2013, 3, 3117-3129.

255 J. K. Beattie, T. W. Hambley, J. A. Klepetko, A. F. Masters and P. Turner, Polyhedron, 1998, 17, 1343-1354.

256 R. Chakrabarty, S. J. Bora and B. K. Das, Inorg. Chem., 2007, 46, 9450-9462.

257 K. Dimitrou, K. Folting, W. E. Streib and G. Christou, J. Am. Chem. Soc., 1993, 115, 6432-6433.

258 K. Dimitrou, A. D. Brown, T. E. Concolino, A. L. Rheingold and G. Christou, Chem. Commun., 2001, 1284-1285.

259 N. S. McCool, D. M. Robinson, J. E. Sheats and G. C. Dismukes, J. Am. Chem. Soc., 2011, 133, 1144611449.

260 S. Berardi, G. La Ganga, M. Natali, I. Bazzan, F. Puntoriero, A. Sartorel, F. Scandola, S. Campagna and M. Bonchio, J. Am. Chem. Soc., 2012, 134, 11104-11107.

261 G. La Ganga, F. Puntoriero, S. Campagna, I. Bazzan, S. Berardi, M. Bonchio, A. Sartorel, M. Natali and F. Scandola, Faraday Discuss., 2012, 155, 177-190.

262 H. Yuan, D. L. Newton, L. A. Seymour, A. Metz, D. Cropek, A. A. Holder and R. Y. Ofoli, Catal. Commun., 2014, 56, 76-80.

263 X. Zhou, F. Li, H. Li, B. Zhang, F. Yu and L. Sun, ChemSusChem, 2014, 7, 2453-2456.

264 P. Sarmah, R. Chakrabarty, P. Phukan and B. K. Das, J. Mol. Catal. A: Chem., 2007, 268, 36-44.

265 A. I. Nguyen, M. S. Ziegler, P. Oña-Burgos, M. SturzbecherHohne, W. Kim, D. E. Bellone and T. D. Tilley, J. Am. Chem. Soc., 2015, 137, 12865-12872.

266 X. Li and P. E. M. Siegbahn, J. Am. Chem. Soc., 2013, 135, 13804-13813.

267 A. Fernando and C. M. Aikens, J. Phys. Chem. C, 2015, 119, 11072-11085.

268 For a recent mechanistic study on the $\mathrm{Co}_{4} \mathrm{O}_{4}(\mathrm{pyr})_{4}(\mathrm{OAc})_{4}$ cubane, see: P. F. Smith, L. Hunt, A. B. Laursen, V. Sagar, S. Kaushik, K. U. D. Calvinho, G. Marotta, E. Mosconi, F. De Angelis and G. C. Dismukes, J. Am. Chem. Soc., 2015, 137, 15460-15468.

269 F. Evangelisti, R. Güttinger, R. Moré, S. Luber and G. R. Patzke, J. Am. Chem. Soc., 2013, 135, 18734-18737.

270 F. H. Hodel and S. Luber, ACS Catal., 2016, 6, 15051517.
271 F. Evangelisti, R. Moré, F. Hodel, S. Luber and G. R. Patzke, J. Am. Chem. Soc., 2015, 137, 11076-11084.

272 A. M. Ullman, Y. Liu, M. Huynh, D. K. Bediako, H. Wang, B. L. Anderson, D. C. Powers, J. J. Breen, H. D. Abruña and D. G. Nocera, J. Am. Chem. Soc., 2014, 136, 17681-17688.

273 X. Li, E. B. Clatworthy, A. F. Masters and T. Maschmeyer, Chem. - Eur. J., 2015, 21, 16578-16584.

274 D. J. Wasylenko, C. Ganesamoorthy, J. Borau-Garcia and C. P. Berlinguette, Chem. Commun., 2011, 47, 4249-4251.

275 D. K. Dogutan, R. McGuire and D. G. Nocera, J. Am. Chem. Soc., 2011, 133, 9178-9180.

276 D. J. Wasylenko, R. D. Palmer, E. Schott and C. P. Berlinguette, Chem. Commun., 2012, 48, 2107-2109.

277 D. W. Crandell, S. Ghosh, C. P. Berlinguette and M.-H. Baik, ChemSusChem, 2015, 8, 844-852.

278 B. Das, A. Orthaber, S. Ott and A. Thapper, Chem. Commun., 2015, 51, 13074-13077.

279 R. McGuire, Jr., D. K. Dogutan, T. S. Teets, J. Suntivich, Y. Shao-Horn and D. G. Nocera, Chem. Sci., 2010, 1, 411414.

280 M. Z. Ertem and C. J. Cramer, Dalton Trans., 2012, 41, 12213-12219.

281 W. Lai, R. Cao, G. Dong, S. Shaik, J. Yao and H. Chen, J. Phys. Chem. Lett., 2012, 3, 2315-2319.

282 H. Lei, A. Han, F. Li, M. Zhang, Y. Han, P. Du, W. Lai and R. Cao, Phys. Chem. Chem. Phys., 2014, 16, 1883-1893.

283 T. Nakazono, A. R. Parent and K. Sakai, Chem. Commun., 2013, 49, 6325-6327.

284 D. Wang and J. T. Groves, Proc. Natl. Acad. Sci. U. S. A., 2013, 110, 15579-15584.

285 A. M. S. Silva, M. G. P. M. S. Neves, R. R. L. Martins, J. A. S. Cavaleiro, T. Boschi and P. Tagliatesta, J. Porphyrins Phthalocyanines, 1998, 2, 45-51.

286 T. Nakazono, A. R. Parent and K. Sakai, Chem. - Eur. J., 2015, 21, 6723-6726.

287 C.-F. Leung, S.-M. Ng, C.-C. Ko, W.-L. Man, J. Wu, L. Chen and T.-C. Lau, Energy Environ. Sci., 2012, 5, 7903-7907.

288 E. Pizzolato, M. Natali, B. Posocco, A. Montellano López, I. Bazzan, M. Di Valentin, P. Galloni, V. Conte, M. Bonchio, F. Scandola and A. Sartorel, Chem. Commun., 2013, 49, 9941-9943.

289 A. Asraf, H. A. Younus, C. I. Ezugwu, A. Mehta and F. Verpoort, Catal. Sci. Technol., DOI: 10.1039/c5cy02157j.

290 H. Wang, Y. Lu, E. Mijangos and A. Thapper, Chin. J. Chem., 2014, 32, 467-473.

291 S. Fu, Y. Liu, Y. Ding, X. Du, F. Song, R. Xiang and B. Ma, Chem. Commun., 2014, 50, 2167-2169.

292 H. Chen, Z. Sun, X. Liu, A. Han and P. Du, J. Phys. Chem. C, 2015, 119, 8998-9004.

293 D. Hong, J. Jung, J. Park, Y. Yamada, T. Suenobu, Y.-M. Lee, W. Nam and S. Fukuzumi, Energy Environ. Sci., 2012, 5, 7606-7616.

294 J. Luo, N. P. Rath and L. M. Mirica, Inorg. Chem., 2011, 50, 6152-6157.

295 M. L. Rigsby, S. Mandal, W. Nam, L. C. Spencer, A. Llobet and S. S. Stahl, Chem. Sci., 2012, 3, 3058-3062. 
296 H.-Y. Wang, E. Mijangos, S. Ott and A. Thapper, Angew. Chem., Int. Ed., 2014, 53, 14499-14502.

297 For a study on the related $\left[(\mathrm{tpa}) \mathrm{Co}(\mu-\mathrm{OH})_{2} \mathrm{Co}(\mathrm{tpa})\right]^{4+}$ complex, see: T. Ishizuka, A. Watanabe, H. Kotani, D. Hong, K. Satonaka, T. Wada, Y. Shiota, K. Yoshizawa, K. Ohara, K. Yamaguchi, S. Kato, S. Fukuzumi and T. Kojima, Inorg. Chem., 2016, 55, 1154-1164.

298 For reviews on Cu-catalyzed aerobic oxidations, see: (a) J. Piera and J.-E. Bäckvall, Angew. Chem., Int. Ed., 2008, 47, 3506-3523; (b) Camilla Parmeggiani and Francesca Cardona, Green Chem., 2012, 14, 547-564; (c) S. E. Allen, R. R. Walvoord, R. Padilla-Salinas and M. C. Kozlowski, Chem. Rev., 2013, 113, 6234-6458; (d) Q. Cao, L. M. Dornan, L. Rogan, N. L. Hughes and M. J. Muldoon, Chem. Commun., 2014, 50, 4524-4543; (e) B. L. Ryland and S. S. Stahl, Angew. Chem., Int. Ed., 2014, 53, 8824-8838; (f) S. D. McCann and S. S. Stahl, Acc. Chem. Res., 2015, 48, 1756-1766.

299 S. M. Barnett, K. I. Goldberg and J. M. Mayer, Nat. Chem., 2012, 4, 498-502.

300 T. Zhang, C. Wang, S. Liu, J.-L. Wang and W. Lin, J. Am. Chem. Soc., 2014, 136, 273-281.

301 W.-H. Wang, J. F. Hull, J. T. Muckerman, E. Fujita and Y. Himeda, Energy Environ. Sci., 2012, 5, 7923-7926.

302 C. M. Conifer, R. A. Taylor, D. J. Law, G. J. Sunley, A. J. P. White and G. J. P. Britovsek, Dalton Trans., 2011, 40, 1031-1033.

303 D. L. Gerlach, S. Bhagan, A. A. Cruce, D. B. Burks, I. Nieto, H. T. Truong, S. P. Kelley, C. J. Herbst-Gervasoni, K. L. Jernigan, M. K. Bowman, S. Pan, M. Zeller and E. T. Papish, Inorg. Chem., 2014, 53, 12689-12698.

304 M.-T. Zhang, Z. Chen, P. Kang and T. J. Meyer, J. Am. Chem. Soc., 2013, 135, 2048-2051.

305 M. K. Kim and A. E. Martell, J. Am. Chem. Soc., 1966, 88, 914-918.
306 N. V. Nagy, T. Szabó-Plánka, A. Rockenbauer, G. Peintler, I. Nagypál and L. Korecz, J. Am. Chem. Soc., 2003, 125, 5227-5235.

307 S. G. Winikoff and C. J. Cramer, Catal. Sci. Technol., 2014, 4, 2484-2489.

308 J. S. Pap, Ł. Szyrwiel, D. Srankó, Z. Kerner, B. Setner, Z. Szewczuk and W. Malinka, Chem. Commun., 2015, 51, 6322-6324.

309 P. Garrido-Barros, I. Funes-Ardoiz, S. Drouet, J. BenetBuchholz, F. Maseras and A. Llobet, J. Am. Chem. Soc., 2015, 137, 6758-6761.

310 For a recent study on $\mathrm{Cu}$-based water oxidation catalysts that highlights the dramatic effect that ligand frameworks can have on the catalytic activity, see: R.-J. Xiang, H.-Y. Wang, Z.-J. Xin, C.-B. Li, Y.-X. Lu, X.-W. Gao, H.-M. Sun and R. Cao, Chem. - Eur. J., 2016, 22, 16021607.

311 X.-J. Su, M. Gao, L. Jiao, R.-Z. Liao, P. E. M. Siegbahn, J.-P. Cheng and M.-T. Zhang, Angew. Chem., Int. Ed., 2015, 54, 4909-4914.

312 C. He and S. J. Lippard, Tetrahedron, 2000, 56, 8245-8252.

313 C. He, J. L. DuBois, B. Hedman, K. O. Hodgson and S. J. Lippard, Angew. Chem., Int. Ed., 2001, 40, 1484-1487.

314 L. Yu, X. Du, Y. Ding, H. Chen and P. Zhou, Chem. Commun., 2015, 51, 17443-17446.

315 S. Nellutla, J. van Tol, N. S. Dalal, L.-H. Bi, U. Kortz, B. Keita, L. Nadjo, G. A. Khitrov and A. G. Marshall, Inorg. Chem., 2005, 44, 9795-9806.

316 W.-B. Yu, Q.-Y. He, X.-F. Ma, H.-T. Shi and X. Wei, Dalton Trans., 2015, 44, 351-358.

317 M. Mahdi Najafpour, F. Ebrahimi, R. Safdari, M. Z. Ghobadi, M. Tavahodi and P. Rafighi, Dalton Trans., 2015, 44, 15435-15440.

318 T.-T. Li, S. Cao, C. Yang, Y. Chen, X.-J. Lv and W.-F. Fu, Inorg. Chem., 2015, 54, 3061-3067. 